\title{
Seminalidad pachasófica del estar-siendo abyayalense
}





\section{¿Resabio ontológico o fagocitación del pensar?}

El indígena es un atesorador lógico: sin cesar reanuda los hilos, repliega incansablemente sobre sí mismo a todos los aspectos de lo real, sean estos físicos, sociales o mentales.

(Levi-Strauss, 1994, p. 386)

Para muchos observadores de la realidad latinoamericana y andina reflexionar sobre los referentes filosóficos y ontológicos que podrían estar en el devenir propio del pensar indígena, mestizo y popular latinoamericano, carece de importancia y de relevancia epistémica, y ello en varios sentidos. Por una parte, se suele confundir lo 'ontológico' como exclusividad del pensar y de la pregunta occidental y, bajo dicho argumento, se afirma una aparente in-actualidad por la pregunta ontológica en Abya Yala, como si tautológicamente lo que es en Occidente, lo está siendo de igual forma en el acontecer andino. Por otra parte, y dado el emerger de lo que se ha denominado como la 'posmodernidad', el valor de lo múltiple y lo diverso parecen desplazar el lugar de la unidad que parecía dar la ontología; con ello también se 'des-ontologizan' las experiencias, los saberes y expresiones que subyacen en lo más propio y particular del sentir de los pueblos del Abya Yala: “(...) los posmodernos ya no criticamos el 'error' en nombre de la 'verdad', no queremos 'humanizarnos' ni buscar el origen de nuestra identidad cultural y tampoco nos 
conmueve la continuidad y la unidad, sino la multiplicidad y el acontecimiento" (Castro, 2011, pp. 40-43).

En necesaria tensión con estos planteamientos posmodernos, que parecen acudir a la muerte de la pregunta ontológica como proyecto mismo del quehacer filosófico, y paradójicamente en la 'multiplicidad y el acontecimiento' que desplaza la 'continuidad y la unidad', emergen los saberes locales, situados y contextuales, siempre complejos, diversos y cambiantes, tanto como subalternizados, y peor aún, estetizados en la jabonosa episteme de la posmodernidad.

Es en este sentido que el problema del ser y del tiempo puede recobrar vigencia y urgencia en la actual modernidad líquida, como le nombra Bauman (2000), no para llegar por esta vía a una suerte de certezas y verdades eternas e inmutables, por demás ajenas al espíritu profundo del pueblo abyayalense, pero sí para recrear, movilizar y retar los marcos del saber filosófico desde la sacralidad relacional que subyace aún en los saberes y conocimientos populares e indígenas del Abya Yala, negados tanto por la estrechez y violencia de los parámetros del pensar moderno/colonial, como por quienes desde la pretendida posmodernidad residualizan la experiencia del pensar americano, debido al hecho de que esta es siempre cambiante y nunca estática. En contraste con lo anterior recobra sentido el aporte del semiólogo argentino Walter Mignolo (1995), cuando afirma que:

(...) Pachachuti, Guamán Poma, Garcilaso, Ixctlilxochitl, Diego Muñoz Camargo, y tantos otros, ya no son solo nombres que hay que restituir a la historia de la América sino, fundamentalmente, formas de decir que tienen para el pensamiento de América, la misma fuerza que Descartes, Freud, Marx o Nietzsche en la historia de la Europa moderna. ¿Cómo proponer un contradiscurso al relato hegemónico construido en las lenguas colonizadoras (...) que convirtió las ruinas griegas y romanas en legítimas formas de pensamiento? ¿Por qué solo pensar a partir de las ruinas griegas y romanas y no de las ruinas andinas y mesoamericanas? (p. 28).

Así, la búsqueda de un sentido del tiempo y de una posible ontología andina, no es propiamente una aculturación producto de la colonialidad del saber, y menos aún, 
una reminiscencia nostálgica y romántica de una evocación a una pureza indígena, andina o latinoamericana que se establece como nuevo telos cultural y epistémico, es más bien lo que el argentino Rodolfo Kusch denominó como fagocitación.

(...) Venimos encarando el problema desde otro ángulo, podemos afirmar que la aculturación se produce solo en un plano material, como la arquitectura, o la vestimenta, en cambio, en otros órdenes pudo haberse producido un proceso inverso, diríamos de fagocitación de lo blanco por lo indígena. Quizá hubo siempre una acción simultánea de los procesos pero nuestros ideales de progresismo nos impiden ver a este último. La fagocitación se da en un terreno de imponderables, en aquel margen de inferioridad de todo lo nuestro, aún de los elementos acumulados, respecto a lo europeo (...) es cuando tomamos conciencia de que algo nos impide ser totalmente occidentales aunque nos lo propongamos (Kusch, 2009, Tomo II, p. 180).

Es en este mismo horizonte que el estudio del tiempo-espacio andino, en diálogo 'fagocitario' con el pensar occidental, puede aportar a la construcción de una filosofía latinoamericana crítica y decolonial. Pero además, las nociones del tiempo andino, enunciadas en el segundo capítulo de esta obra, no podrán adquirir una dimensión filosófica fuera del marco general en el que las cosas son-están en el pensar andino popular. Acaso, todo lo anterior evoca, no la pureza de un saber unívoco y universal, sino la "hediondez" propia de una lógica cósmico-relacional de la negación.

\section{Preeminencia del estary autenticidad del ser}

El filósofo argentino Rodolfo Kusch, en su búsqueda de lo más profundo del pensar indio y popular, pronto se percata de las complejidades que tiene reflexionar sobre lo que es desde el sentimiento andino. Es allí donde contrasta con la lógica occidental de lo que es, es decir, la connotación positiva de las 'cosas', con el uso frecuentemente dado en el castellano del verbo estar y la connotación de negación que es propia a esta condición del estar. 
La preeminencia del verbo estar en expresiones cotidianas del castellano, como: estoy trabajando, estoy leyendo, en contraste con el sentido de expresiones como: yo trabajo, yo leo, evidencian la manera en que el estar tiene cierto distanciamiento del carácter connotativo de las cosas, como si estas estuvieran atadas a las circunstancias, a lo circunstancial. En este sentido el estar aparece ligado a la circunstancia y por lo tanto condiciona al verbo mismo, se pone en medio del yo y del verbo, como si se adoptara una actitud contemplativa, más que objetiva/subjetiva.

Esta misma característica que acentúa el estar, parece ser común en el devenir existencial de los amerindios “(...) pareciera consistir en sumergir todo lo que es estable dentro de la circunstancia. Como si aquello en que se anda fuera el producto momentáneo de una gran inestabilidad que se cierne en un trasfondo que no se ve" (Kusch, 2009, p. 527).

Aquello inestable en lo que se sumerge el estar, se opone a la función ontológica del nombrar, elemento propio de la racionalidad occidental y que lingüísticamente se enuncia con el verbo es, 'esto es...', lo que en cierto sentido reduce el campo del es al del estar. De tal suerte que lo que queda no es una consubstancialidad que pertenece a la 'cosa' nombrada, sino a la circunstancia en la que esta está dada, lo que obligaría a predicar con respecto a un sujeto no propiamente un verbo sino una circunstancia, una mera temporalidad del es, en la que el sujeto está siendo y no propiamente es ontológicamente: "En cierto modo se circunstancializa el ser, se lo hace morar en la circunstancia (...) Y en tanto se sustituye el es por el estar en el ser se puebla el mundo con una dramática inestabilidad” (p. 527).

Para superar la inestabilidad propia del mero estar, la racionalidad ha respondido por medio de la creación de objetos, de cosas y de nombres, los que aparentan un sentido de estados permanente; de tal suerte que se pretendió superar el 'miedo a los dioses' y la angustia existencial de lo impermanente por vía del objeto, de lo nombrable y enunciable.

Dados los sentidos transitorios del estar en su uso corriente, como en el hecho de que la expresión indica, entre otras funciones semánticas: ubicación, un estado de ánimo, duración y disponibilidad, todas estas vinculadas con funciones señalativas en tanto no comprometen al sujeto, ya que nada anuncian de él, y este 
aparece también sumido en la circunstancia misma como cuando se dice 'estar alegre', 'estar en casa', allí se evidencia cierta intensión de separar el mundo de la existencia que correspondería al estar, del mundo de la esencia y la permanencia que correspondería al es.

El estar ha sido residualizado en la tradición filosófica occidental, justamente por la búsqueda de aquello permanente, pues la seguridad de la razón e incluso el objeto mismo de la filosofía no podría ser lo inestable, pues por el contrario, lo inestable debe ser superado para llegar al ámbito del ser donde lo aparente se torna fijo y permanente. De allí que podría afirmarse que el estar, como condición existencial y circunstancial del sujeto, ha sido subalternizado en el es colonizador del ser.

Como el estar corresponde al ámbito de la antidefinición, queda segregado y adquiere con ello una honrosa autonomía, según la cual, legaliza y estabiliza su régimen. Cabe pensar que no era tan peyorativo todo lo referente al estar, y que responde a un pensamiento que era implícito al cuerpo cultural que lo había creado (p. 529).

Por ello el filósofo argentino Rodolfo Kusch, ve una gran riqueza de sentido en la expresión del estar para reflexionar sobre la manera como las cosas son están siendo' en Abya Yala. Por una parte, el estar es una expresión derivada del latín stare que siempre evoca inquietud, en tanto a un 'estar de pie', mientras que ser, deriva de sedere, de estar sentado, en reposo. Hay allí una oposición fundamental entre inquietud y reposo, siendo la inquietud fuente de 'miedo' que a su vez dará lugar a los 'dioses' en la dinámica de Abya Yala; por su parte la racionalidad moderna ha cubierto el miedo y la ansiedad del estar, con los 'objetos' que ocupan el lugar de los 'dioses'. El mundo moderno occidental que creyó emerger al margen de los 'dioses' y de la fe, solo les encubrió con los objetos y nombres que les 'permite' afirmar lo que es.

Sin embargo, cabría indagar si aquella inquietud propia del mero estar, no es acaso una forma de comprensión mucho más abarcadora que el fundamental ser, 
de si el conocimiento producto de la nominación estática del es no es acaso apenas un momento, un 'ahora' del estar en general, aquello que el argentino considera como un pensar seminal que se pregunta no solo por lo nombrable, sino también por aquello innombrable de lo que está, acaso también una nueva forma de ser y permanecer.

Kusch observa que es justamente esto a lo que se enfrenta en la obra cumbre del castellano, El Quijote de la Mancha, el personaje caballeresco de Don Quijote, quien angustiado por el mero estar proyecta sobre sí aquello que debe ser, a saber, un caballero, mientras su compañero fiel, Sancho Panza, está como arrojado al mero estar, a la circunstancia; "El quijote representa el desgarramiento de querer ser, pero que termina en un lamentable y simple estar no más” (p. 530).

Un análisis filosófico de este mismo problema del estar-ser lo encontramos en la monumental obra de Heidegger Ser y tiempo (1927). En esta, el alemán ubica el problema del ser caracterizándolo o diferenciándolo del ente, de las cosas, esto es a lo que el filósofo denominó la "diferencia ontológica" (Heidegger, 1996, p. 37). Por medio de esta 'diferencia ontológica' el autor enjuicia la tradición occidental que se ha olvidado del ser y no ha podido comprender esta diferencia fundamental, pues se cayó en la metafísica que pronto confundió el ser con la divinidad, es decir, se entiende la ontología como "onto-teología". Ahora bien, dado que el ser no puede ser entendido desde la idea teológica, ni meramente por medio de los entes, dado que el ser no es propiamente un ente, será necesario constituir otro punto de partida que involucra una analítica existencial del único ente que se pregunta por el ser, el Dasein ${ }^{61}$. El Dasein no es otra cosa que el "ser-ahí" y la ontología necesita dilucidar e iniciar por la pregunta del ese ser-ahí, de aquel ente que se pregunta por el ser.

61 Si bien el único ente que se pregunta por el ser es el hombre, Heidegger busca tomar distancia de esta terminología antropológica y humanista que desea superar con la noción del Dasein, pues considera que estos términos están anclados aún en la metafísica y epistemología occidentales que justamente han dado la espalda a la pregunta por el ser (Maldonado, en, Castro, S. \& Grosfoguel, R. (Eds.) 2007, p. 141). 
Una de las características del "ser-ahí” es que es un ser 'arrojado', que 'ex-iste', es decir, que está proyectado al futuro, y por ser-ahí, el Dasein se encuentra bajo la modalidad anónima del "uno", das Man, donde se encuentran subsumidas sus propias posibilidades. Es en contraposición a la reproducción del hombre en las determinaciones del das Man, que Heidegger opone una actitud que considera como 'auténtica', en tanto que el Dasein se relaciona auténticamente consigo mismo y proyecta así sus posibilidades más propias. Esta autenticidad es posible solo en la medida en que el Dasein despliegue el poder-ser más propio que surge con la anticipación de la única posibilidad inexpugnable del hombre, a saber, la muerte. En este sentido la muerte es el factor individualizador, por lo que su anticipación y la ansiedad que le es propia, permiten al Dasein desligarse del das Man, definiendo así su propio proyecto 'ex-istencial', ergo, existir auténticamente.

Si bien es cierto gran parte de la filosofía de Heidegger en torno a la analítica existencial del Dasein, versa sobre el estar y ello en diálogo con el tiempo, como posibilidad misma del darse -donarse- del ser del Dasein, el alemán interpreta este estar como ex-istencia, en tanto estar fuera del ser, a lo que opone una 'existencia auténtica', aquella que va de la 'existencia' al ser. Ahora bien, el tema del ser que constituye una obsesión de la filosofía europea, en tanto herencia del pensar griego es “(...) acuñada filosóficamente por el pensamiento occidental, y por eso mismo tiene que llegar a nuestro siglo $\mathrm{xx}$, como algo absolutamente vacío, según lo demuestra Heidegger" (Kusch, 2009, pp. 530-531).

Es justamente por la vaguedad y olvido real del ser en la filosofía occidental que Heidegger dará paso a una filosofía del tiempo, lo que no está al margen y es comprensible dadas las dinámicas del pensamiento alemán burgués producto de la Revolución Industrial, es decir, de una manera de superar 'existencia inauténtica' con la generación de la connotabilidad de los objetos, lo que obliga a superar el simple estar, por carecer este de connotaciones que permitan la estabilidad: 
(...) un pensamiento que solo ve en términos de causas no habrá de comprender qué ocurre con aquel [estar] (...) ha de ser seguramente por eso mismo que aparece una filosofía del tiempo, esa obsesión del quehacer como instancia inalienable de la burguesía alemana (p. 531). [Añadido nuestro].

\section{Excurso: del Dasein auténtico y la experiencia de la muerte al ser colonizado como damné}

El quehacer como despliegue de las posibilidades mismas del ser del Dasein, como aquello que evidencia no solo su 'ser-ahí', sino su 'proyectarse al futuro', es la expresión de una existencia auténtica que de cara a la anticipación de lo más propio del Dasein, a saber la muerte, permite al sujeto desconectarse del das Man. Si el anticiparse a la muerte constituye la posibilidad de lograr una autenticidad 'individual', en un sentido colectivo el Führer posibilitaba para la Alemania de Heidegger, la autenticidad colectiva.

En este sentido, no solo se da la creación de objetos como resultado del quehacer, sino la guerra misma en tanto quehacer que confronta la muerte, permitía el vínculo entre la autenticidad colectiva y la individual.

La guerra proveía una forma de conectar ambas ideas: las guerras del pueblo (Volk) en nombre del líder proveían el contexto para una confrontación con la muerte, lo que fomentaba a su vez la autenticidad individual. La posibilidad de morir por el país propio en una guerra se convertía, así, en un medio que facilitaba, tanto la autenticidad colectiva como la individual (Maldonado, 2007, p. 142).

Pensar así la guerra misma, en vínculo con la posibilidad de una existencia auténtica, parece evocar la historia del ganador de la guerra, sin embargo, cabe interpretar también que el vencido puede, desde esta perspectiva, alcanzar también su autenticidad en la guerra, pues también este se confronta en esta con la muerte, solo que experimentándola en su corporalidad, en su diario vivir. Esto último, de la experiencia real y cercana con la muerte por parte de los vencidos, 
es justamente el devenir del estar abyayalense desde tiempos de la colonia, pues la muerte aquí no aparece como un evento que totaliza la existencia misma, sino como parte de la cotidianidad del estar en tanto pueblo 'vencido,' 'subalternizado' y 'colonizado'.

Ello supondría que el 'Dasein abyayalense', si se pudiese hablar del tal, es un ser particular dado que su experiencia con aquello ineludible que constituye al Dasein auténtico heideggeriano, es decir la anticipación a la muerte, es una experiencia también particular pues hace parte de su cotidianidad, por lo que el vínculo con esta es diferente al Dasein europeo que se des-aliena del "uno" por medio de la confrontación con la muerte.

Los sujetos racializados son constituidos de formas distintas de las que forman a sujetos, otros y pueblos. La anticipación de la muerte no es tanto un factor individualizador como un rasgo constitutivo de su realidad. Para ellos es la muerte, no "el uno", es aquello que los aflige. El encuentro con la muerte siempre viene de alguna forma muy tarde, ya que la muerte está siempre a su lado como amenaza continua (p. 143).

Así, la anticipación de la muerte no es propiamente un factor que des-aliena de la angustia de lo "uno", sino una característica permanente del tiempo andino; de la misma forma que el 'estar viviendo' siempre integra el 'estar muriendo' y ambas son condiciones de la existencia, no como permanencias sino como circunstancias que acaecen al 'puro vivir', al 'mero estar'. De tal manera que lo que genera angustia no es propiamente el dominio del das Man, con su proyecto de 'deber ser' y 'tener que ser' e incluso del 'quehacer', sino la muerte misma "que siempre está a su lado como amenaza continua” (p. 143). En este horizonte la existencia auténtica no es anticipación a la muerte, sino su contrario, la evasión de la misma, pues esta siempre acosa la existencia como manera cotidiana de estar, como lo "uno" al Dasein heideggeriano.

En este sentido Heidegger no captó que la proyección de la autenticidad como prototipo del hombre europeo, también encubría cierta opacidad del ser, en tanto 
devenía en un ser colonizado, en un aspecto colonial del ser, que en su seno pare no solo la lógica del 'mercader con el atado de mercancías', como le nombra Kusch, sino también la tendencia de someter todo a una razón connotativa que por demás ha tenido su extremo en la racialización de los otros, producto de la modernidad/colonial.

El lado colonial del ser sostiene la línea de color. Heidegger, sin embargo, pierde de vista la condición particular de sujetos en el lado más oscuro de la línea de color, y el significado de su experiencia vivida para la teorización del ser y para la comprensión de las patologías de la modernidad (p. 143).

Este Dasein colonizado es apenas enunciado tímidamente por el alemán en la evocación de un tal “Dasein primitivo" (Heidegger, 1996, p. 75), al que poca atención presta el filósofo. Sin embargo, y allí la cuestión crítica de su propuesta, el alemán toma como prototipo 'daseínico' al sujeto europeo sin captar allí las relaciones de poder que subalternizan al Dasein primitivo. Si bien pone en cuestión el apalabramiento del sujeto desde la noción de hombre, por su connotación metafísica, no cuestiona el hecho de que en la modernidad no se puede hablar propiamente de un modelo singular de lo humano, pues acaso ello represente justamente una modalidad del Dasein colonizador y racializador que pretendemos contrastar con el estar andino.

Él necesitaba dejar de tomar a Europa y al hombre europeo como modelos, para así poder des-encubrir las dinámicas complejas del Dasein en el mundo moderno -tanto en Europa como en su periferia, y en los espacios internos a ella, donde también se encuentran los Dasein colonizados, a los que denominaremos aquí como condenados o damnés- (Maldonado, 2007, pp. 143-144).

Dado que Heidegger ubica como prototipo de Dasein auténtico al sujeto moderno-europeo, no capta allí el otro polo de la modernidad, según la cual el cogito cartesiano es soportado no sobre el Cogito ergo Sum "pienso luego soy", es decir, no propiamente en el ego cogito, sino en el ego conquiro. Es decir, en el hombre 
imperial y dominador, sobre el cual el ego cogito recobra otras dimensiones analíticas y hace su reflexión (Dussel, 1996, p. 133), y sobre el que poco se ha profundizado.

Según esta matriz de análisis propuesta por el argentino Enrique Dussel, el ego cogito que ha fundado aparentemente la conciencia de lo que es la modernidad, como proyecto emancipatorio del sujeto, comienza no propiamente con la duda metódica cartesiana, sino con el ego conquiro que despliega previamente esta duda sobre el ser de los 'otros' colonizados. En otras palabras, si la certidumbre producto del cogito ergo sum cartesiano descansa en últimas sobre la certeza que supera toda duda, a saber, el ego, el "yo", en tanto res cogitans, dicho ego cogito descansa a su vez en el ego conquiro que le antecedió por lo menos un siglo como experiencia existencial, es decir, en el sujeto práctico y conquistador.

Así, la "certidumbre" sobre la empresa colonial y el fundamento del ego conquiro quedan anclados, como el cogito cartesiano, en la duda o el escepticismo. El escepticismo se convierte en el medio para alcanzar certidumbre y proveer una fundación sólida al sujeto moderno. El rol del escepticismo es central para la modernidad europea. Y así como el ego conquiro antecede al ego cogito, un cierto tipo de escepticismo sobre la humanidad de los sub-otros colonizados y racializados sirve como fondo a las certidumbres cartesianas y su método de duda hiperbólica (Maldonado, 2007, p. 134).

Sobra redundar aquí sobre las nefastas consecuencias de la experiencia colonial de los indios abyayalenses en relación con el despliegue del ego conquiro, basta la mención para identificar una matriz colonial del ser de los 'otros', como conquiro del cogito, como prototipo de la existencia del hombre europeo.

Si bien el filósofo y matemático francés René Descartes imaginó a un genio con la capacidad de engañar la conciencia, y desviar el sentido de lo que es, no se percató siquiera de la influencia del ego conquiro en sus presuposiciones, como tampoco de la pregunta misma por el ser como le cuestionará el mismo Heidegger. Sin embargo, llama la atención que el filósofo alemán aunque cuestiona el giro subjetivista y meramente epistémico de la racionalidad moderna llevada a cabo por el francés, debido principalmente a que esta se centró en el ego cogito, y olvidó la 
pregunta por el único ente que se pregunta por el ser y en definitiva al ser mismo, también consideró que la máxima cartesiana de Cogito ergo sum, introducía en cierta forma, aunque no dimensionada así por el francés, el concepto del ser, solo que acentuando la sentencia de manera inversa, es decir, ya no un "pienso, luego soy", sino un "pienso, luego soy" (Heidegger, 1996, p. 46), esta acentuación de la fórmula le permitía a Heidegger apalancar la pregunta por el ser.

Ahora bien, de lo que no se percata ninguno de los dos intelectuales, es de la relación que tiene el ego cogito como resultado del ego conquiro, pues ignorando esto, es decir, la matriz con la cual se establece el ego conquiro, se pierde de vista que el "pienso" y el "soy", la cuestión epistémica por un lado y la ontológica, por el otro, conservan en la negación de lo otro su posibilidad de ser, en tanto que 'otros' no piensan ergo otros no son; ello se constata sin problema alguno en la dinámica del colonialismo europeo en Abya Yala.

De esta forma descubrimos una complejidad no reconocida de la formulación cartesiana: del "yo pienso, luego soy" somos llevados a la noción más compleja, pero a la vez más precisa, histórica y filosóficamente: "Yo pienso (otros no piensan o no piensan adecuadamente), luego soy (otros no son, están desprovistos de ser, no deben existir o son dispensables)" (Maldonado, 2007, p. 144).

Es sumamente relevante la crítica del alemán Martin Heidegger a la filosofía de Descartes, en tanto que identifica que tras la preeminencia epistémica en la fórmula cartesiana se da un cierto olvido de la pregunta por el ser, lo que era propio del pensar filosófico de la modernidad a la que Heidegger reaccionaba. No obstante, al no captar la dinámica del ego conquiro en el ego cogito, es decir, la colonialidad epistémica en la que se funda el cogito, se dará también lugar a la posibilidad de la 'negación ontológica', pues "No pensar se convierte en señal de no ser en la modernidad" (p. 145) (énfasis nuestro). Justamente en la experiencia de la colonia en Abya Yala se puede constatar el vínculo entre la colonialidad del conocimiento europeo y la negación y subalternización de los saberes ancestrales, lo que tuvo 
como consecuencia la negación ontológica, la imposibilidad del ser de los abyayalenses, la adjudicación de la barbarie para unos y la civilización para otros ergo la dominación del ser-estar americano.

En este sentido el damné, propuesto por Fanon (1963), a diferencia del Dasein, no es propiamente un 'ser-ahí', proyectado, eyectado al futuro, sino un ente que al no poder ser, a los ojos del ego conquiro, al serle negado su ser, es un algo que existe paradójicamente en el "no-estar-ahí", en el simple mero estar donde reina la incertidumbre, acecha la muerte y la negación donde se da la fagocitación del ser.

\section{El quehacer para escapar al estar: respuestas al requerimiento de lo absoluto}

Ahora bien, el mero estar no es una forma, resultado o modalidad de una opresión y subalternización óntica a manera del damné de Fanon, ello supondría por demás la proyección en el tiempo por medio de la técnica y la creación de objetos que permitan la connotación y lo permanente. Por el contrario, es la forma más profunda de 'ser', en tanto que el estar abyayalense que parece ser también una negación ontológica, asume la existencia de una manera tan particular, solo que ahora es el damné que en su experiencia de estar más auténtica capta lo que es-estando.

De allí que el "sujeto" (runa/jaqi) abyayalense no sea un gran creador de objetos, menos aún de industria, ni de revoluciones industriales como las de Europa y Norte América, pues su estar no requiere la proyección y menos aún una tal existencia auténtica, pues la negación y la muerte siempre están presentes, su estar permite entonces tomar distancia del quehacer como una forma de ser, de 'ser alguien', lo que superficialmente la racionalidad moderna en su ego conquiro ha querido denominar como 'subdesarrollo' que no es otra cosa sino su deseo de ser aquello que aún no son y que pretenden serlo por medio del quehacer.

El quehacer se plantea (...) como un hacer un qué definido para un simple estar bien o mejor, como si fuera nada más una manera de movilizar el estar. Se trata de trabajar todo el día para alcanzar comodidades, y estas por su 
parte se logran comprando los qué o cosas. Uno se moviliza y hace cuando quiere estar bien y se está bien en tanto se tiene (Kusch, 2009, p. 531).

Es por ello que en contraposición a un estar bien, parece primar un simple estar que no se soporta en la permanencia, sino en la inmanencia de la circunstancia. De allí que mientras la razón occidental se proyecta teleológicamente en el despliegue de una línea del tiempo -en cuanto a una serie de 'ahoras' proyectadas en un tiempo infinito- de su poder-ser más propio, y de allí el quehacer que inunda el mundo de objetos, de permanencias, en Abya Yala aunque hay objetos y quehaceres, estos no buscan el estar bien o la 'buena vida', sino el Buen estar, el Buen Vivir, el Suma Qamaña/Suma Kawsay, para lo cual las 'cosas' que están-siendo en el tiempo no son signo de una condición positiva de mejora del estar y en consecuencia del ser, pues en el Suma Qamaña no pretende un 'vivir mejor', sino un 'vivir en armonía y relación', lo que la exterioridad de los objetos como extensión del 'ex-istencia' no permite en la lógica del quehacer occidental.

En este mismo sentido se contraponen dos modalidades del estar bien, una que se despliega dando lugar a lo visible, a lo nombrable, a lo connotable y permanente, y otra que le comprende como una modalidad del estar, aquella que está en relación y armonía con.

De tal suerte que mientras el quehacer para la modalidad del pensamiento occidental busca llenar con alguna 'cosa' el arrojo y el temor del simple estar, es decir, de la condición daseínica, para el pensar abyayalense el quehacer y el qué del mismo, no son más que una exterioridad de la que no se puede predicar nada, como en 'esto es' pues siempre es el resultado del quehacer “(...) se da fuera, enredado en los objetos, y monta todo lo que es sobre el esfuerzo que hay que emplear para lograrlo, y no responde a lo que realmente se busca, el requerimiento de encontrar una verdadera plenitud" (p. 532). Y justamente no se encuentra allí la plenitud, el Suma Kawsay/Qamaña, debido a que el quehacer es la huida del mero estar, pero siempre hacia el ámbito de los objetos que se crean, poseen y tienen, los que siempre tienden a una connotación visual que “(...) se contradice con lo que hay de profundo en esa conciencia de estar (...)" (pp. 532-533). 
Es justamente en esa imposibilidad del quehacer para alcanzar la plenitud que el mero estar supera lo connotativo, es decir, lo que es. Así, cuando se predica 'estoy caminando' no es el quehacer quien determina al sujeto, como en 'yo camino' o 'yo trabajo', sino que la condición de la acción, el quehacer, es meramente una apariencia, una visualidad que no dice nada de la plenitud; de allí que el tener en Abya Yala no es siquiera cercano al ser-estar -por supuesto que lo es en las clases sociales emergentes que identifican su ser social y personal con el tener, aquellas a las que Kusch denominó las clases 'pulcras'-, sino que se requiere un estar como soporte de la existencia misma.

Se sabe, además, que si no se hace así, el tener mismo conduce a la novedad de tener más cosas y, como bien dice la sabiduría popular "eso a nada lleva". Además, no se entiende la vida misma sin esa posibilidad de poder toparse alguna vez con la propia plenitud. Y esto ocurre porque el estar se limita a que cada uno se siente en ese límite de no ser más que algo que está y que puede llamarse hombre. No es el hombre creado por la burguesía europea, sino ese otro, asediado por la policía y el ejército, susceptible de ser computado estadísticamente, obligado a emitir votos, al cual se le atribuyen opiniones que nadie toma en cuenta, y al cual se le asigna un sueldo mensual, todo ello para certificar convincentemente su heroica humanidad, de la cual en el fondo, todo el mundo duda (Kusch, 2009, p. 533).

En este sentido, el filósofo argentino logra captar a su manera, no solo aquello de la condición previa del ego conquiro en el ego cogito y su consecuente negación ontológica, sino que además, en su fenomenología del estar también evoca a un damné que ve negada su condición de humanidad, su 'eseidad', al verse inmerso en la imposición ya no del "uno", del das Man, sino del quehacer, como despliegue del "uno".

Ahora bien, un estar como el que subyace en el devenir abyayalense, es decir, un estar como mero habitar, co-habitar en tanto radicalización del 'aquí-ahora' y como posibilidad de lo que hay, como aquello de que 'todo tiene su tiempo', puede acaso constituir un verdadero horizonte de partida para un análisis de la existencia y la ontología, campos aún inexplorados desde el horizonte andino. 
El estar visto desde esta perspectiva se corresponde plenamente con la noción de la pacha que se ha enunciado en el segundo capítulo de este texto; la pacha como posibilidad de todo lo real pero que siempre está abierta a una significación más amplia que la connotación, por lo que esta siempre evoca y contiene por medio del ritual y de la celebración como captación de la realidad en un 'aquí-ahora'. Por ello afirma Kusch que "El estar y el pacha parecieran ser la misma cosa" (p. 534).

La pacha, como el así de lo que esta-siendo, como condición de posibilidad de lo real, en tanto tiempo-espacio, tiene su concreción conceptual en el estar, y es por ello que Occidente se arroja al quehacer, como forma de dominar el así y superar la angustia de un mero estar como verdadera condición auténtica del existir, como relacionalidad entre el así y el estar.

El tema del estar no gira, entonces, para el ciudadano, como tampoco para el indígena, en torno a la civilización y al progreso, sino en ese "no más que vivir", con ese asombro primario de sorprenderse de que uno sea ingeniero en una gran empresa, y ver esto como un milagro. Se trata de la sensación de despojo que acompaña la supuesta riqueza potencial de nuestra América, esa a la cual nos sentimos reducidos, aun cuando seamos ejecutivos (p. 534).

La preferencia de la circunstancia en la actitud que privilegia el estar, como condición de temporalidad, siempre se sobrepone a la definición, a la datación, tanto como a la proyección de una vida arrojada al quehacer, que al no soportarse en el mero estar siempre busca lo que es sin percatarse siquiera de la preeminencia y primacía del estar. Por otra parte la circunstancia que prima en el estar no permite sin más estar atado al "uno", al 'deber-ser', al 'tener-ser'; simplemente permanece en el estar-siendo, en el así espacio-temporal de la pacha, de allí que "Estar es, en suma, ubicarse en esa encrucijada que se abre en el así, donde asoma una auténtica visión del hombre. Es la ventaja de ser subdesarrollados. Por este lado podemos jugar al chance de nuestra propia historia” (p. 535). 
Si bien el estar toma la inestabilidad de la circunstancia, esta es trascendida también en el estar, en tanto radicalización de la realidad, lo que permite entrever un sentido de lo absoluto en esta noción. El mero estar se corresponde entonces con el requerimiento de la connotación que da lo absoluto, solo que ello en Occidente ha sido depositado meramente en aquello que se ve, en la creación de objetos como extensión del ego cogito, mientras en el pensamiento seminal abayayalence, con su consabida radicalización de la realidad, el estar contiene lo absoluto, pues trasciende con creces el sentido de la 'cosa' dada a la vista como sentido privilegiado del conocimiento.

En este mismo aspecto es que Heidegger en búsqueda de la pregunta por el ser, parte de la vida cotidiana, que sin embargo el autor siempre circunscribe a un pensamiento connotativo y causal que le amarra a la racionalidad que quiere superar. Así, bajo la noción de una existencia auténtica e inauténtica, el alemán rechazará esta última por su conformidad en cuanto a los objetos, la comunidad y el requerimiento de lo absoluto, tan deplorable también para el pensamiento posmoderno, tanto como cierto para el mero estar.

Lo auténtico de la existencia, parece tener un gran parecido con el ideal de hombre burgués que siempre está anticipándose al tiempo, en un despliegue de las 'cosas' en el mundo de la vida con el ánimo de buscar las causas lúcidas, estables y permanentes. En ese sentido Kusch inquiere el pensamiento del alemán al afirmar que esto se comprueba en la terminología que usa Heidegger: "El ser se evapora porque en ningún momento puede darse como a-la-mano o ante-la-vis$t a$, y no puede haber fe en cosas que no se tocan, ni se ven, o sea en lo que no es consciente y no tiene causa" (p. 539).

Es por ello que el Dasein auténtico es un buen prototipo del emprendedor-mercader que ocupa el campo de lo absoluto con el quehacer y los productos, las cosas que de él puede 'crear', como proyección y anticipación en el tiempo de su propio ser. De allí que más que una "evaporación del ser" se da una sublimación del mismo. En este sentido tanto el occidental como el abyayalense comparten el requerimiento de lo absoluto, "Pero aquel lo concreta, mientras este lo vive en negativo a ocultas y siempre segregado, como para la masa" (p. 539), como en el 
entramado mismo del das Man; uno en el quehacer positivo-proyectivo y otro en la anticipación del mero estar que evoca lo absoluto en el rito, en lo innombrable y no en la 'cosa-objeto'.

El sentido de lo absoluto que se da entonces como requerimiento del mero estar, no es propiamente una particularidad del runa/jaqi -sujeto- andino, sino que es un requerimiento de la mera existencia, solo que en el caso del pensar occidental, este es cubierto por medio del quehacer y los objetos que permiten la connotación.

El simple estar como despojo y desnudez no sería tolerable, si no lo sostuviese un cierto afán de lo absoluto. Este da consistencia al estar y es lo que torna milagrosa la vida del indígena o la del habitante anónimo de la gran ciudad. El estar es la instalación en el hábitad real de la casa, el paisaje, el trabajo, la ciudad o lo que fuera. Pero este hábitad tiene dos dimensiones, o se lo vive tal como se da, lo cual implica un pensar connotativo, causal, o se lo advierte como un punto de reposo o caída en el largo trayecto que existe entre los opuestos innombrables que pueden darse como vida o muerte, fasto o nefasto (...) lo absoluto es por su parte la comprensión seminal y tensamente arqueada sobre el desgarramiento en que siempre se halla el cosmos. Solo por este absoluto es posible tolerar un simple estar cuando este llega al despojo (p. 540).

Este afán de connotación, propio del pensar hegemónico occidental como respuesta a la angustia que genera la necesidad de lo absoluto, no es propiamente suplido por lo connotado, en tanto enunciado de lo dado, de lo que es, sino también la reducción de lo que está-siendo en la circunstancia, al ámbito de lo visual. Es en este mismo sentido que el filósofo argentino considera que la religión y la ciencia occidental solo son "absolutos visualizados", que por una parte representan en realidad la "burocratización de la fe" como también de la inteligencia. Lo que por demás es una expresión más del despliegue de la colonialidad del ser y del saber.

De tal suerte que un mundo pensado meramente por medio de lo visual, es un mundo que establece una determinada relación con los objetos y el quehacer 
para llenar el requerimiento de lo absoluto, sin embargo, dada su visualidad, este razonar ha coartado el pensar seminal y emocional, desplazando así la perspectiva del mero estar, donde el absoluto está colocado en otra 'cosa' -Sache- y no en las cosas - das Ding-.

El absoluto entonces se da en lo innombrable más que en lo connotable, pues mientras el primero cae en el vacío de la circunstancia, del desgarramiento mismo del estar no más, donde se esconde su posibilidad de captación que desborda con creces el sentido de verdad que puede 'acoger' lo connotado; el segundo pretende afirmarse en lo objetivado-observado. En este mismo sentido hablaba Heidegger (2009) del ser en relación al tiempo cuando afirma que el ser tiene un tiempo asignado en el que es "Ser y tiempo se determinan recíprocamente, pero de una manera tal que ni aquel -el ser- se deja apelar como algo temporal ni este -el tiempo- se deja apelar como ente" (p. 21).

Lo absoluto visto como requerimiento de la propia existencia, mejor, del mero estar, es condición que 'acosa' a los occidentales tanto como a los indígenas y mestizos del Abya Yala. En cambio, la connotabilidad del mundo y de las cosas, como forma de enfrentar lo absoluto, es solo una parte, aquella denominada como consciente de las causas, de las utilidades, de las cantidades, pero que nunca da cuenta del mero estar-ahí como absoluto. Acaso esto mismo se encuentra en el sentido estudiado del aka o uca pacha, en tanto condensación de todo lo real en el así-aquí-ahora de la pacha, en el aka como chakana donde está la vida misma. El espacio-tiempo del ucamahua o akamahua toma todo el estar del sujeto tanto como el del objeto:

(...) a partir de este punto (...) el objeto es realmente no más que una mera circunstancia (...) pero menor que uno, porque uno siquiera puede llevar a la conciencia todo lo que es hombre, como una circunstancia mayor y más heroica, como una caída original. Y con este ya se roza el absoluto (Kusch, 2009, p. 545). 
Esta "caída original" como forma de dar sentido al requerimiento de lo absoluto por medio de lo nominable, es satisfecha en el pensar popular por medio del ritual y la celebración, pues en este espacio-tiempo celebrativo, la realidad-toda, la pacha, es co-re-presentada por medio del ritual mismo, que siempre integra algo mucho más que 'cosas' y 'objetos' y por ello abarca con mayor posibilidad un sentido de lo absoluto que no le encubre en lo nominado, sino que permanece abierto a la fragilidad de lo inestable, de lo nuevo, de lo cambiante, tal como ha devenido la existencia humana en Abya Yala.

Justamente es la inestabilidad que produce la experiencia vivida en las urbes latinoamericanas para las inmensas mayorías no 'pulcras' y 'cultas', aquellas aún no totalmente blanqueadas por la razón occidental y con mayor profundidad en las comunidad indígenas que convergen en estos espacios urbanos, donde emerge una radical manera del estar.

Las posibilidades de un tal ser desplegado en el tiempo por medio del quehacer que permita satisfacer la pregunta de ¿quién soy? se encuentran siempre con la respuesta del "no más que vivir", del simplemente 'estoy' y ello por la realidad en la que se da un sistema laboral, de quehacer, atomizado por las lógicas capitalistas. Así, la pregunta ontológica al ¿quién soy? lúcidamente no permite una respuesta categórica como 'soy conductor' 'soy mesero', sino la incertidumbre misma que se refleja en el sistema de quehacer social que obliga a un 'por ahora trabajo como conductor' 'por ahora estoy siendo mesero', lo que vincula la pregunta por el quien con el hecho de llevar a cuestas el absoluto en la inestable circunstancialidad. Acaso ello supone una tensión con la noción ontológica de Heidegger, según la cual, la presencia, es la manera como el ser es determinado por el tiempo "el ser es determinado como presencia por el tiempo" (Heidegger, 2007, p. 20), pues para el pensar abyayalense, el quien siempre es dudoso, misterioso y circunstancial, por ello mismo, no es la presencia donde se temporaliza el ser, sino es el estar el que circunstancializa la presencia, de allí que la presencia no sea una determinación del ser en el tiempo, sino la ausencia misma. Parece ser todo lo contrario a lo propuesto por el alemán: 
(...) no es más que tomar conciencia de la circunstancia heroica del así que uno mismo es, pero en esa dimensión del indígena, cuando este piensa que el hombre (...) se relaciona con los "tantos del juego". Decir esto del hombre, a su vez, es definirlo por su ausencia, y es lograr su verdadero sentido, ya que dicha ausencia roza esa zona en la cual se dan los innombrables y donde presionan los dioses. Es la verdad del absoluto que se refleja en la encrucijada del así [y no del ser] (Kusch, 2009, p. 546). (Énfasis en negrilla y agregado nuestro).

De tal manera que el sentido de lo absoluto no está dado y donado por la presencia en el tiempo, sino por la ausencia que da lugar a "los dioses", por la dinámica del mero estar donde se da una verdadera y autentica vivencia filosófica, pues “(...) la única vivencia realmente filosófica: [es] la sorpresa de descubrir la encrucijada que se da en el mero estar, y sobrellevar el sentido de lo absoluto, aunque por negación" (p. 546).

Esta misma negación en la que las cosas están inmersas no solo en la positividad de su nominación, de su eseidad, sino en la ritualidad que las trasciende, fue uno de los elementos en los que se profundizó en el segundo capítulo para poder abordar las nociones espacio-temporales en la sabiduría indígena. Allí se constató la manera como en el pensar indígena la negación constituía la posibilidad última de las cosas, como con el camión del ritual de Eucaliptus que si bien no se le ignora como camión, se duda la posibilidad de su utilidad, por lo que es menester que los dioses y el ritual intervengan. En este sentido el camión no era solo la positividad en cuanto a ser un objeto destinado para el transporte de mercancías, sino que más allá de ello y por medio del ritual, su objetividad es integrada, relativizada si se quiere, en la imposibilidad de usar ese camión si 'los dioses no lo permiten', si no es el 'tiempo propicio', 'si no es la voluntad de Dios'; posibilidad, por demás, más cercana a la noción de la muerte para el proyecto existencial del Dasein heideggeriano, en cuando situación ineludible de la existencia que a la nominación del objeto denominado conceptualmente como 'camión' se le da. 
Si la muerte es lo único verdaderamente ineludible a lo cual el Dasein heideggeriano se ve constantemente impelido en su proyectar-se auténtico, la negación de la positividad y utilidad de las 'cosas' cumplirá el mismo horizonte de objetividad que en Occidente, solo que ahora en la conciencia abyayalense -algo así como un equivalente homeomórfico-, pues al asumir lo ineludible, a saber, la negación de las cosas, el sentido de lo absoluto es sintetizado en el ritual, que siempre trasciende el campo de lo conceptual-connotativo-procedimental.

Si bien, el filósofo alemán escritor de Sein und Zeit, no captó las dimensiones de la negación en el 'estar-ahí' inauténtico, su noción de la temporalidad como horizonte de posibilidad del ser ya comenzaba a reconocer cierto carácter de negatividad que se daba en la temporalidad, entendida esta como la sucesión de 'ahoras', como el tiempo vulgar, "La infinitud del tiempo no es una preeminencia del tiempo o algo similar, sino una determinación privativa, que caracteriza un carácter negativo de la temporalidad" (Heidegger, 2000, p. 328).

Esta existencia que parte de la negación, en cuanto a un mero estar, se puede observar en toda una suerte de prácticas cotidianas en las urbes latinoamericanas, las que no han sido desprovistas de una dosis muy compleja de la manera como las cosas son en Occidente y aún están-siendo en Abya Yala. Así, es común encontrar sujetos que en su relación con los objetos que integran su quehacer cotidiano - no para vivir-ser, sino 'simplemente sobre-vivir', estar- en las urbes, se enfrentan a las 'cosas' de una manera muy particular, como vaciados de racionalidad causal y de medio-fin; como cuando un mensajero motorizado pone un escapulario al timón de su moto y le da nombre, 'la verraca', pero como negando su posibilidad objetiva de 'cosa mecánica' e integrándola a su relación con el mundo de la vida, casi como un sujeto relacional y no meramente un mecanismo u objeto de trabajo. Por otra parte, mientras este mensajero 'encarga' su objeto-sujeto a los dioses -escapulario-, el occidental seguramente se proyectará en la positividad-objetividad y programará un seguro a 'todo riesgo', que siempre resultará inútil para el primero, pues la circunstancia siempre le asedia y le sobrepasa, lo que no permite una tal anticipación. 


\section{Consecuencia de un pensar basado en el estary la superación de la connotación por el 'operador seminal'}

Para la ciencia seguramente la actitud negativa en la que los objetos están siendo puede representar aquello que Kusch denominó "hediondez", versus la "pulcritud" del pensar, casi como la clásica diferenciación entre el logos y la doxa para los griegos. Así, el trabajador de la urbe, tanto como el indio de la sierra podrían ser denominados por la razón logocéntrica, como sujetos enceguecidos por un pensamiento mítico, siendo esto último sinónimo de ignorancia, precariedad conceptual e irracionalidad. Sin embargo, lo que se da aquí no es propiamente una actitud irracional, sino un pensar seminal que trasciende el campo de lo objetivo, superando la lógica epistémica tradicional que va del sujeto al objeto, circunscribiendo al objeto en la experiencia circunstancial del mero estar.

De tal suerte que se comprende la razón por la cual los objetos rituales en un sinnúmero de manifestaciones religiosas en Abya Yala, no tienen esencialidades permanentes, sino situacionales y contextuales, es decir, en determinado momento el objeto en el ritual puede representar 'esto o aquello', pero dada otra circunstancia el mismo puede representar lo contrario. En el rito católico la copa de la comunión siempre tendrá la misma función celebrativa y conmemorativa, no así la alimaña del brujo, el amuleto del abuelo, que dependen del 'tiempo-espacio', de la circunstancia emocional-objetiva en la que se integra el elemento. "Desde aquí ya no se trabaja con objetos y con elementos denotables, sino con significados condicionados emocionalmente, y que, en su forma extrema, se estructuran en valores" (Kusch, 2009, p. 586).

Para la razón occidental la emocionalidad muchas veces es opuesta, está en tensión con el conocer y el pensar, pues la actitud objetiva de la razón requiere el distanciamiento de aquello que se pretende conocer, lo que obliga a dejar de lado todo el potencial del conocimiento seminal. Ahora bien, para el pensar popular abyayalense el 'vector' emocional del pensar no contiene la carga o complejo negativo que la modernidad le ha adjudicado, por el contrario, en lo emocional: 
(...) las denotaciones son cada vez más difíciles por cuanto ellas se tornan disponibles. La verdadera función que el área emocional tiene pareciera ser principalmente energética, pero de tal modo que, sin embargo, su fuerza hace el sentido de lo que se está queriendo decir (p. 587).

Ello supone que la validez de un determinado juicio desde este horizonte existencial no ha de ser juzgada por el enunciado mismo, sino por el vínculo que se da entre lo negado y lo afirmado, por lo connotado y lo experienciado de lo connotado, pues allí ya no surge un mero conocimiento, como momento del pensar, sino un pensar a nivel de revelación que a su vez determina todos los demás contenidos del conocer. De allí que para el argentino el pensar popular sea realmente un pensar no lineal, sino mandálico, en tanto que los elementos conscientes ocupan un segundo plano "(...) y se destaca en cambio un campo central que nada dice en concreto, pero está cargado de significación" (p.589).

A riesgo de la simplificación que supone cualquier ejemplificación de lo complejo, podrían mencionarse como elementos que evidencian lo anteriormente enunciado, las expresiones espacio-temporales que un campesino puede dar cuando se le pregunta por ¿dónde o a cuánto tiempo está un determinado lugar?, a lo cual este puede responder 'allí nomasito', lo que no dice 'nada' realmente del dónde, pero sí establece una relación circunstancial-emocional con la distancia y el espacio, pues ese 'allí nomasito' puede ser bien, a una o dos horas de camino, como a quince minutos. Lo nombrado aquí es la circunstancia. Otra expresión muy particular que deja entrever la racionalidad espacio-temporal es aquella que responde a la pregunta occidentalizada de ¿en cuánto tiempo llega?, con la expresión 'ahorita'; nuevamente el 'ahorita' no connota, no cuantifica, sino que está en íntima relación 'subjetiva' y circunstancial, pues con el 'ahorita' no se sabe cuánto tiempo es, todo depende nuevamente de lo circunstancial-emocional.

Esto mismo pareciera una variante del hecho del pensar, pero constituye a nivel popular la finalidad principal del pensamiento. Se piensa para abordar el área emocional y no al revés. No es entonces el caso de la ciencia que apunta a delimitar los objetos. Por eso podemos decir que si nuestra forma 
aculturada de pensar tiende a ver cosas, la fórmula propia y natural del pensar apunta a lo contrario, o sea a ver significados (...). En todo esto se trata de movilizar la psique en un sentido profundo para efectivizar la posibilidad de vivir, y esta efectivización no la da sino la función totalizante de la emocionalidad (pp. 589-590).

Esta emocionalidad de la que habla Kusch, se debe al hecho de asumir la existencia en el mero estar, y ello supone ya no un ver al mundo y a los objetos en su horizonte de utilidad, de manualidad, sino simplemente como lo 'así es', como aka pacha, lo que parece ser una resignación al estar arrojados, del mero estar-eyectadosen-el-mundo. Sin embargo, más allá de una aparente pasividad ante el mundo al percibirlo como lo 'así-es', se da una especie de vacío emocional que permite captar la realidad en su totalidad, pues 'allí' se toma conciencia de lo real, de "uno mismo" como sujeto y de las cosas, solo que transformadas ahora en símbolos, en tanto que este es unificador de sentidos.

A su vez, en tanto la realidad adquiere un valor simbólico, se impone una hermenéutica para descubrir lo que está detrás del dato sensible, a nivel de teología cotidiana, ya en un campo sagrado (...). "Lo sagrado en todo esto brinda la posibilidad de algo más, o sea un orden más estable que se afianza y favorece en tanto uno cree en él" (p. 591).

Esta aprehensión de la realidad en su totalidad por vía de lo simbólico, implica cierta negación de las 'cosas', en tanto que estas apuntan más allá de su simple positividad como objetos y se funda en la relación existencial del sujeto con las mismas. De allí que el pensar sea una forma de dar fundamento a la existencia y el conocimiento de las 'cosas' solo represente un 'momento' de ese pensar general, lo que supone que en la negación de las cosas, incluso en la mera opinión sobre las mismas, se dé una afirmación de la existencia como mero estar, como si estas fueran dadas a manera de 'revelación', sin el requerimiento de una causa-efecto indispensable para su conocimiento "por eso, en vez de la afirmación, lo fundante es negar para lograr la revelación de lo sagrado" (p. 592). 
Ahora bien, en el primer capítulo se profundizó en la relación que Heidegger establece entre el Dasein y el comprender, siendo este último al igual que el tiempo, parte de la constitución y fundamento mismo del Dasein, lo que en sí mismo trasciende el limitado campo del conocer, pues de esta manera el comprender está ligado a la existencia misma, "Existir es esencialmente, aunque no solo, comprender" (Heidegger, 2000, p. 332). De tal suerte que para el alemán lo que 'comprende' en últimas el Dasein, es su propio ser y ello es el reconocimiento de que el ser del Dasein es un ser-en-el-mundo. De esta manera el comprender auténtico heideggeriano, se convierte en comprender-se, pues la comprensión del ser del Dasein no se da por medio de los entes en el mundo, sino de la comprensión de su ser más propio, en tanto ser proyectado en el tiempo, pues "el tiempo es aquello a partir de lo cual entendemos algo como ser" (p. 337).

Tanto en Heidegger como en el pensar abyayalense expuesto por Kusch, hay algo previo y más fundamental al conocer, pues se soporta en la existencia misma. Solo que en Heidegger se da el 'comprender' como 'comprender-se' en el tiempo, es decir, como comprensión del ser del Dasein, mientras el 'pensar' abyayalense no se preocupa tanto por el ser, ni del Dasein, ni de las 'cosas', por el contrario lo que ocupa el pensar andino es la afirmación de la existencia como mero estar, porque 'así-son' las cosas.

En este sentido para estas dos tradiciones filosóficas, el 'conocer' queda instalado como un momento de algo que lo totaliza, que le da sentido último, que le hace diferente, claro y nominable, es decir, que le funda y le soporta en el horizonte existencial propio, de tal suerte que el conocer que funda al ego cogito, es solo una pequeña parte, un pequeño detalle del requerimiento de totalidad del pensar.

Por otra parte, tanto en la tradición existencial abyayalense como en la heideggeriana, la condición existencial del Dasein y el runa/jaqi, son fundamentales en el proceso tanto de 'comprensión' como del 'pensar', es por ello que:

(...) lo conocido termina por incorporarse a lo que el sujeto cree que él mismo es a través de sus experiencias (...) es el mecanismo del "ya sé" con el cual lo que se propone, o informa, entra a constituir una parte importante de todo lo que el sujeto ya sabe, y lo que ya sabe, es la base de su existencia (Kusch, 2009, p. 593). 
De allí que la novedad siempre es incorporada y leída en el horizonte del "ya sé", y por ello su interés no es tanto el conocer mismo, sino la incorporación de aquello conocido en el horizonte existencial del estar, de lo sagrado mismo. Por ello lo que se conoce siempre tiene el requerimiento de la totalidad brindada en el caso andino en la idea de lo sagrado, en el requerimiento de una teología popular que totalice la parcialidad de lo conocido en el ámbito de la experiencia de lo sagrado. Ello entra en clara tensión con el comprender auténtico heideggeriano que se centra en conocer el ser más propio del Dasein, lo que regresa nuevamente al ego cogito cartesiano soportado en el ego conquiro de que se ha hecho alusión.

Por su parte, para el pensar andino el campo de lo sagrado siempre funciona como lo 'otro', mientras la novedad como lo 'mismo', de allí que todo lo que se conozca, 'lo mismo' requiere de 'lo otro' en tanto instancia de lo sagrado. Ello constata un pensar totalizante en el que coexisten los dos planos, solo que el mero estar que siempre está dado en el campo de la incertidumbre, de lo nefasto y de los dioses, de allí que: "Entre el saber que apunta a la sacralización y el simple conocer, surge (...) como un elemento de extracción emocional, pero suficientemente inteligible para conceder, un sentido fundante a lo que se conoce" (p. 595).

Este saber andino tiene dos vectores, uno vinculado con 'yo-mundo' y otro con lo 'sagrado-profano', pero justamente en medio de estos dos es que se da lo que Kusch denominó un 'operador seminal'62, según el cual lo 'mismo' pasa a ser lo 'otro', es decir, recobra un sentido totalizante y religioso entrando en el campo de la negación de lo objetivo, de la inestabilidad propia del mero estar y representada en el rito por el 'campo' de los dioses.

El proceso que va de lo 'mismo' a lo 'otro' comprende una totalidad del pensar por el simple hecho de abarcar mayores posibilidades del mismo, pues siempre se interconecta profundamente con el existir.

62 Los operadores seminales para Kusch (2009) "Son fuentes energéticas que brindan la posibilidad de decisión y cargan de significado el mundo" (p. 602). 
Además, cada nueva determinación va completando horizontes de totalización del pensar según los cuales este se enreda cada vez más en el vivir mismo, de tal modo que el pensar hace siempre a la concepción del mundo donde adquiere el saber absoluto (p. 596-597).

Ahora bien, esto nos remite nuevamente a la problemática ontológica en tanto que la preeminencia del pensar andino no pone su acento en el ser sino en el estar, como circunstancialización del ser. Es decir, se da una radicalización del mero existir, a un punto tal que lo que el sujeto ve en el plano 'objetivo' del pensar, es puesto en la duda de lo 'otro', como reza el refrán popular "hay que tener ojos en la nuca". Ante lo que se ve, es necesaria otra manera de 'ver' que totaliza, da sentido y horizonte a lo visto, y ello trasciende el simple conocer, pues lo dicho en cuanto a la 'cosa' que se ve, nunca expresa la verdad de tal, sino que esta siempre rebasa la afirmación y al sujeto mismo que la enuncia. Lo que es el es de las 'cosas', simplemente es enunciado en la circunstancialización, en la preeminencia de un 'ahora' del que solo se puede predicar un 'aquí y ahora creo en esto', pues 'todo tiene su tiempo' y “'el creo esto' es decisivo para el existir y puede rebasar al conocimiento científico: hace por ejemplo que un campesino prefiera al curandero y no al médico" (p. 598).

Ello supone que el fundamento mismo del existir, lo más profundo del mismo sea el estar y no el ser, como propuso toda la tradición occidental, de allí también una noción kairética -de kairos- del tiempo en el pensar andino, pues lo que es el runa/jaqi depende de la circunstancia temporal y ello es inestable, como lo es el mero estar bajo el asedio de las cosas, del trabajo, de la vida, del desempleo, del ejército, de los paramilitares. Por ello a la muerte se le rehúye como lo haría la existencia inauténtica heideggeriana, pues el afrontamiento de la misma cae en el sin sentido en tanto que esta está en la cotidianidad del runa/jaqi, habita asediándole, por lo que el espíritu heroico y de auténtica existencia sería el huirle y conservar la vida de todo cuanto 'así-es' o está-siendo.

La distancia entre Occidente y América es la que media entre el pensar culto y el popular. Aquel, al contrario de este, no se previene tanto de un ver visual sino del modo de concebir lo abstracto. Ha cancelado el aspecto concreto 
y físico de la cosa, y por eso mismo es menos consistente. La consistencia se simula a nivel del pensar no más. En esto se da el típico "desarraigo" del pensar culto en general, porque es un pensar sin realidad, que está montado para no poderse confesar un "esto creo". Por eso también apunta a ser y no a estar, siempre que esta diferenciación señale de alguna manera la oposición de los dos tipos de pensar (p. 599).

De lo anterior se desprende no solo que el conocer sea una pequeña parte del comprender heideggeriano y del saber-pensar andino, sino que el pensamiento 'culto' y 'académico' también es un caso particular dentro del pensar en general, este último asume la emocionalidad del mero estar en el horizonte del pensar mismo y por ello evita la connotación y en cambio, el otro acude a la inmediatez de la acción, pues al emerger los operadores seminales por medio de lo inestable, de lo negado, se logra la estabilidad existencial, la superación misma de la angustia.

De tal suerte que el pensamiento abayayalense no busca la verdad en una determinada proposición, la que a su vez es una abstracción, "sino de referir a una verdad que se instala en el existir mismo, con la cual se juega la ubicación en el estar no más" (p. 602). Acaso ello represente la necesidad de pensar en la superación del principio del 'tercer excluido' para colocar en el estar mismo al 'tercero' como incluido, pero ello solo es posible por el despliegue de los operadores seminales.

En este sentido es que el pensar andino puede aportar a la creación de un horizonte de la totalidad del pensar, en tanto:

En nuestro caso americano en cambio se trata de encontrar la posibilidad de un horizonte de totalidad del pensar. Es así como recobraríamos la jerarquía del pensar, su colocación en lo que creemos que debe ser lo universal, y que esto mismo lo habremos de lograr recién cuando encaremos la aparente desagregación del pensar. Y solo conseguiremos esto cuando advirtamos que la lógica que se nos impone bloquea intencionalmente la decisión seminal, y pretende evitar que el operador seminal sea nuestra fuente de decisiones (p. 603). 
Aquí se constata otra manera de un despliegue de lo que hoy se enuncia como colonialidad del saber/poder (Lander, 2000), en tanto un colonialismo epistémico que impide y bloquea al operador seminal que no consiste en decir lo que es falso o verdadero, sino en la posibilidad de decidir y no en la afirmación misma. Lo contrario a esto sería hacer residir el existir en la afirmación abstracta y no esta en el mismo existir ${ }^{63}$ :

Si la primera es el producto de una seria inquietud respecto a la ciencia, la otra surge de una no menor preocupación por el puro hecho de vivir. Es lo que hace la diferencia entre un pensar culto y un pensar no culto o sea más próximo al vivir, pero es probable que sea también la oposición entre una lógica utilizada por los colonizadores y otra empleada por los colonizados (Kusch, 2009, p. 604).

Esa experiencia del existir, del estar de una determinada forma, en un determinado espacio, preña de sentidos particulares la experiencia misma del tiempo y de los es en este. De allí que a luz de una experiencia-existencia que llena el requerimiento de lo absoluto no en la palabra que connota, ni en la positividad de los objetos, sino en lo simbólico emotivo de lo ritual, surja una manera particular, sui generis, en el que las cosas más que ser, están siendo, en un horizonte que antes que objetivo es relacional, tanto como emocional, lo que no significa propiamente que sea, en términos de la racionalidad occidental, un saber subjetivo.

63 Kusch (2009, pp. 603-605) llama la atención sobre el hecho de que la mayoría de pensadores occidentales, quizá a excepción de Heidegger, hayan descartado las categorías aristotélicas para referirse al 'estar', tales como: acción, pasión, tiempo, lugar, posición, hábito, lo que los llevó fuera de la profundidad del pensar. 


\section{De la preeminencia del estar a los principios fundamentales de la racionalidad andina: el őv y la racionalidad cósmica}

La experiencia existencial del 'puro vivir' o del mero estar, es justamente el soporte, el presupuesto desde el que se puede enunciar una determinada ontología del tiempo en el pensar andino; una racionalidad que opera, sí bajo otros presupuestos de ser, pero siempre consistente con la experiencia más propia del estar abyayalense.

Esta racionalidad da siempre cuenta de la experiencia existencial desde la que se interpreta la 'realidad', desde la que se ordenan y valoran los parámetros del 'puro vivir', de allí que Estermann (2006) afirme que "La 'racionalidad' de una cierta época, cultura o etnia se manifiesta en el conjunto de los 'fenómenos prácticos' o 'pragmáticos' de sus miembros" (p. 101). Ello supone, por demás, la superación de una visión de la racionalidad que se establece como fuente de la que deben emanar las prácticas y costumbres, sino que más bien este conjunto de manifestaciones, son lo que las mantiene estructuradas, ordenadas en un determinado horizonte que constituye la racionalidad misma.

De tal suerte que la racionalidad vista en este horizonte, no es lógica (en el sentido estrictamente occidental del término), esta es solo una manera de abordarla, por cierto la que Occidente ha privilegiado, sino 'pre-lógica', es decir que funda y soporta toda modalidad del pensar. Así, la 'racionalidad' sería entonces la 'lógica' (no necesariamente 'ratio-mórfica') inherente a una cierta estructura socio-cultural, dentro de ciertas coordenadas espacio-temporales. El hecho mismo de que la racionalidad 'lógica' de Occidente sea la que comúnmente se denomina como 'razón', solo evidencia la matriz colonial desde la que este modelo de racionalidad se ha erigido, en tanto ego conquiro.

Justamente la ontología occidental, antes del giro filosófico que dará Heidegger a la pregunta por el ser, se ha apalabrado hasta el momento desde una racionalidad predominantemente cognoscitiva, es decir, desde una racionalidad-lógica que 
olvida la pregunta por el ser, de allí, las críticas que el alemán hará al francés René Descartes, pues este se ocupó menos del ser y más del conocer, al punto que ubicó al ser como segundo momento del conocer, Cogito ergo sum. Ahora bien, es sabido que el escritor de Ser y tiempo, retomará la sentencia cartesiana y enfatizará no propiamente el cogito, sino el sum, ubicando así en el centro de la reflexión, no al conocimiento sino al ser mismo de quien conoce, y en ello justamente radica la importancia de su extenso estudio del tiempo como análisis previo a la pregunta por el ser, como pregunta por las condiciones en las cuales emerge el único ente que se pregunta por ser. De allí también la imposibilidad de pensar al ser sin el tiempo, pues en este último el primero se da, se 'dona'.

La novedad del abordaje ontológico propuesto por Heidegger, es sin lugar a dudas de alcances medulares para la configuración de una filosofía occidental, de un pensar occidental que rompe con los paradigmas racionalistas que buscan desde allí dar respuesta a la realidad, al es de las cosas. Mientras para Heidegger el ser de las cosas se da en el tiempo, es 'presencia' en el tiempo, para la mayor parte del pensar occidental el es no está presente sino que se 're-presenta' mediante el acto cognoscitivo. Es decir, el ser es aprehensible en el conocer del sujeto, y este conocer es mediado por el concepto que más allá de los entes logra captar la esencia de la realidad.

De tal manera que la racionalidad occidental, con notorias excepciones como en el pensar de Heidegger, se ha caracterizado por ser un pensar onto-gnoseológico, pero este visto desde las bifurcación de la realidad. Es decir, aquello que es, es dado en una diátesis ontológica entre existencia-esencia, sustancia-accidente, temporalidad-eternidad, realidad-apariencia, de donde se hace necesario un proceso de $a$-letheia, de 'revelación' que supone un distanciamiento entre la realidad óntica -Das Ding- y la representación de las mismas -el sujeto-. De allí también que Heidegger invierta la perspectiva y parta desde una analítica del Dasein, cuya condición principal es que este ex-iste, como un ser arrojado en el mundo y proyectado al futuro, en el tiempo.

Ahora bien, si Heidegger permite agrietar los paradigmas desde los cuales Occidente piensa la realidad, lo que es, y cómo se manifiesta este -en el tiempo-, 
es verdaderamente la racionalidad andina la que dará un salto cualitativo en el abordaje de la realidad, de aquello que es, de la pregunta ontológica por la verdad de las cosas. Para esta lo real, lo que es no puede estar 're-presentado' por medio del concepto o la abstracción matemática, sino realmente 'presente' en forma simbólica. Es decir, la realidad no se da únicamente en el tiempo, sino principalmente en lo simbólico-ceremonial, de allí que el vínculo con la realidad no sea la palabra sino la inserción simbólica-ritual de la comunidad en aquello que está-siendo presente, y este estar siendo del ritual, por supuesto que como Heidegger lo menciona, está dado en el tiempo, pero no en cualquier tiempo, sino en el tiempo propicio, es decir, el tiempo de la propiciación, del pago, del despacho.

De tal suerte que lo que es, tiene un tiempo propicio en el que es de tal o cual otra forma, de allí que más que ser, la realidad está-siendo, pues el es de las cosas, no es inherente al tiempo -no es transtemporal-, sino que se circunstancializa su esencia en el 'ahora', aquel que el alemán denominó el 'tiempo vulgar' -la serie de ahoras-.

Lo anterior supone una nueva analítica ${ }^{64}$ del Dasein, o dicho en contexto, una nueva simbólica del runa/jaqi, pues mientras la primera busca fragmentar y dividir los sentidos para hallar lo permanente, la segunda unifica los sentidos para sumergirse en la pacha siempre dinámica, inconstante y cambiante. Es en este sentido que el runa/jaqi no capta la realidad como algo diastático, sino que sabe que esta es co-presencia, como una 'ahora', aka pacha, del 'ser-junto', del Mitsein heideggeriano, solo que no en su sentido existencial, sino como característica cósmica que trasciende toda diástasis entre ser humano y mundo extra-mundano:

64 Llama la atención que mientras el alemán propone como punto de partida de la pregunta por el ser una analítica del Dasein, pregunta por demás que responde al tiempo moderno al que el filósofo quería reaccionar, en Abya Yala se propone una inmersión simbólica del runa/jaqi. Y llama la atención, pues la analítica está relacionada con la fragmentación, con la división de un todo en sus partes, mientras la simbólica etimológicamente unifica los sentidos, sumerge al individuo en la totalidad de la pacha; lo que podría representar una ontología mucho más profunda que aquella que busca siempre fragmentar para hallar lo constante, lo permanente. 
La celebración ('re-creación', 'culto') no es menos real que la realidad misma que aquella hace presente, sino más bien al revés: En lo celebrativo, la realidad se hace más intensa y concentrada (synballein). El 'símbolo' es la presentación de la 'realidad' en forma muy densa, eficaz y hasta sagrada; no es una mera 're-presentación' (Abbild) cognoscitiva, sino una 'presencia vivencial' en forma simbólica (Estermann, 2006, p. 105)

Esta manera particular, existencial, de comprender el mundo del runa/jaqi andino, no es como ha supuesto la racionalidad occidental, una versión de un pensamiento mágico. Por el contrario, dicha apreciación solo evidencia el mito de la razón diastática de Occidente, que establece la separación artificiosa, por demás, entre lo profano y lo sagrado, entre sujeto y mundo. Ello se constata no solo en el hecho mismo de que el objeto no tiene para el andino ningún poder salvífico, ni tampoco el runa/jaqi busca adueñarse y apoderarse, be-greifen, del objeto, sino que al contrario "la realidad se sirve del ser humano para su presencia intensificada (y a fortiori: 'salvífica') (p. 106).

Esa 'presencia intensificada' de la realidad, supera con creces las diástasis desde las que Occidente ha pensado el mundo, y se aproxima a la expresión heideggeriana de un Dasein que es ante todo un, Hören des Seins, un oidor del ser, es decir, que el Dasein es co-partícipe de la realidad del ser, como lo es el runa/ jaqi de la Pacha. Así, el pensar andino comparte lo que Heidegger expresa cuando habla de la presencia -das Sein West- o presentación -An wesen heit- de lo que es -An wesen- como una característica óntica de aquello que es, superando así la perspectiva de un sujeto opuesto al acontecer y 'presentación' del ser, pues ha de recordarse que el Dasein es un Hören des Seins.

Se podría hablar de una "semántica ontológica" andina, si no tomáramos el término de la "ontología" en un sentido demasiado técnico. La realidad no está presente como un 'material' crudo que hay que procesar mediante la forma de la cognición; la realidad está presente como 'símbolo', es decir: como un complejo de signos concretos y materiales que se refieren mutuamente, unos a otros (p. 106). 
De tal suerte que para el runa/jaqi, la realidad se da en el vínculo relacional que se condensa en el símbolo, y acaso ello también pueda profundizar aquello que Heidegger evocó del Dasein, aquel que es un 'ser-en-el-mundo'; esa mundanidad del Dasein, es decir, esa implicación ontológica de que el ser humano es principalmente un ser en relación con el mundo, es profundizada y conocida vitalmente por el runa/jaqi andino, a través del ritual y la celebración.

Ello supone, si no una superación, sí un nivel mucho más fundamental, más vital, más hondo - más filosófico- de captación de la realidad que aquel que pretende 'reduplicarla' por medio del concepto, como si lo que es, fuera meramente algo lógico, de donde deviene la idea de que el logos sea el verdadero ser. Dado que para el runa/jaqi andino el logos, es solo un momento de abstracción de la realidad, este no ocupa un lugar preferencial para la dilucidación de lo que es, acaso será algo de tercer orden, pues "El runa/jaqi andino no 'representa' el mundo, sino lo hace 'presente' simbólicamente mediante el ritual y la celebración. Lo conoce vitalmente" (p. 107).

Más allá de la interpretación que ofrece Estermann, de la 'presencia simbólica' de la realidad en el pensar andino, cabría preguntarse si el runa/jaqi hace 'presente' la realidad por medio del ritual y la celebración, o si esto puede ser mejor entendido a la inversa, es decir, si cabe la posibilidad de que el ser humano andino 'se-presenta' ante la realidad por medio del ritual. Ello supondría acaso matizar también la noción kuschiana del mero estar, pues lo que se daría es que por medio del ritual el runa/jaqi se sumerge a sí mismo en aquella realidad del ser-se deja acoger por este- que no puede ser captado, como bien lo saben los occidentales, por medio de los entes, pero tampoco por medio de la palabra y la lógica. En efecto, ello haría que el ser no fuese algo asible por el sujeto, sino aquello en lo que este puede involucrarse, relacionarse por medio de la celebración-ritual.

\section{El arjé andino: otra actitud hacia lo que es}

Por largo tiempo la reflexión filosófica se ha servido de la idea 'sustancialidad-sustancia' para dar respuesta a la pregunta por el arjé. Dicho abordaje de la realidad desde la noción de 'sustancialidad', tendrá sus primeros cuestionamientos en las 
críticas del posestructuralismo y de la posmodernidad epistémica, donde se interpreta la idea de 'sustancia', bien sea como un meta-relato o como mito fundacional de la razón occidental.

Hasta la época contemporánea, la respuesta filosófica al arjé era un determinado 'ente', comprendido como 'sustancia' y ello en todas sus interpretaciones y versiones. Desde la tradición monista del Hen de Plotinio, y el Deus sive natura de Spinoza; al dualismo de Descartes y Aristóteles con sus respectivos, res cogitans-res extensa y hylé-morphé; como en la tradición dualista el eidé de Platón y las mónadas de Leibniz ${ }^{65}$; hasta Heidegger quien cuestionará la onto-teología, no se trasciende aún de la noción de 'sustancialidad' para hablar de lo que es. Al respecto, comenta Estermann que en las tradiciones occidentales:

La noción 'sustancia' es un concepto relacional (pero no una relación), porque solo se la define contrastándola con el concepto opuesto de la 'accidentalidad': 'Sustancia' es lo no es 'accidente', y 'accidente' es lo que no es 'sustancia', tertium non datur. El uno (sustancia) 'es en sí mismo', y el otro (accidente) 'es en otro' (p. 108).

En este sentido, la noción de sustancia, aunque en sí misma es un concepto relacional, toma la relación como un 'accidente', en tanto característica no-esencial de la sustancia. Es decir, si bien la relación es una característica de la sustancia, esta es una característica exterior, pues desde esta perspectiva, primero existe 'algo' que se relaciona con 'otro' algo; una sustancia que se relaciona con un accidente. De allí también la diástasis entre sujeto y objeto en que la relación se da entre un sub-iectum como sustancia, o terminus ad quo y un ob-ietum, o terminus ad quem; pero la relación misma es accidente tanto para el uno como para el otro.

$65 \mathrm{Al}$ respecto de Leibniz, Estermann evidencia la forma como éste trató de una forma particular la idea de la relacionalidad como sustancialidad. Amplíese en: Estermann, J. (2009). Individualität und Kontingenz: Studie zur Individualitätsproblematik bei Gottfried Wihelm Leibniz. Berna-Francfort/M. 
Sin embargo, para el pensar andino el arje, el principio, es la relación misma. Es como menciona Estermann "la verdadera 'sustancia andina"' (p. 108), en tanto que la relación es 'esencial' a la cosa y no meramente un accidente, como si fuese algo que le acaece a la 'cosa'. En este sentido, no sería apresurado pensar que un equivalente homeomórfico de lo que es para la racionalidad occidental el concepto de sustancia o 'ente', es la 'relación' misma en el pensar andino; de allí también puede inferirse la importancia de figuras físicas y filosóficas como las chakanas, puentes, mediaciones en las que las cosas -en su sentido filosófico- son relacionadas, es decir, se convierten en 'realidad' en 'sustancia', solo en el vínculo relacional.

Es en este horizonte filosófico-religioso que el ritual y la celebración de los indios, pero también del campesino y del pensar popular en las urbes, funciona como una chakana hermenéutica para comprender el lugar 'real' en el que el mundo, las 'sustancias', las cosas son-están, co-presentes. De allí también el fuerte poder del símbolo como expresión de una racionalidad que piensa lo que es desde la relación, y no como las cosas son en relación y oposición a otras. Si lo anterior es cierto, ello implica que: "lo que la ontología occidental llama 'ente' ('sustancia' en sentido aristotélico), para la racionalidad andina es un 'nudo' de relaciones, un punto de transición, una concentración relacional” (p. 109).

Es por ello que el tiempo en el pensar andino es una forma de chakana, en tanto en este subyace la relación que permite que se de lo que es, y esto que es, no es lo mismo todo el tiempo, sino que por el contrario es-estando, pues el tiempo mismo es circunstancializado, es preso de la situación dado que en esta emerge la relación que posibilita aquello que es. Por ello, se dice que 'el tiempo es propicio para' y no que 'esto se da en el tiempo'.

Esta relacionalidad en la que las cosas son en el pensar andino, es lo que podría denominarse como un 'mito fundante' del pensar andino, pues ello se expresa no solo en su estructura epistémica, sino en su percepción ontológica de la realidad abyayalense.

De ello da cuenta también toda la estructura lingüística de Occidente que concentra el peso de las oraciones en el sujeto, mientras que el quechua y el aimara lo hacen en el verbo, pues este es el 'relacionador', el condensador ontológico de la oración. 
De allí también se puede comprender el hecho de que para la racionalidad occidental la idea del individuo sea central para la comprensión de la realidad, mientras que en el pensar andino dicha noción es justamente un 'nada', un no-ente, algo que no es concreto, pues no se le puede encontrar su inserción en las múltiples relaciones que integran la realidad total, previamente ordenada al sujeto que la observa: "Si una persona ya no pertenece a la comunidad local (ayllu) (...) es como si no existiera; una persona aislada y des-relacionada es un ente (socialmente) muerto" (p. 110).

Por demás, aquí radica una de las causas por las que el proyecto filosófico de conocimiento ilustrado de la modernidad, en su actual versión capitalista neoliberal, no tiene sentido alguno para el devenir del profundo pensamiento andino. Mientras la razón ilustrada privilegia la desvinculación del sujeto de aquello que pretende conocer, sea esto la naturaleza, el cosmos; para la racionalidad andina ello sería nada menos que la sentencia a muerte del runa/jaqi, pues este solo es, en tanto 'nudo' relacional, en tanto chakana o puente que fija la relación como lo esencial de la realidad, de lo existente. De allí que: "El verdadero arjé para la filosofía andina es justamente la relacionalidad de todo, la red de nexos y vínculos que es la fuerza vital de todo lo que existe. No 'existe' (en sentido muy vital) nada sin esta condición trascendental" (p. 111).

Así, el problema que ha tenido 'fundacionalmente' la filosofía para conciliar la forma como las 'sustancias' se relacionan con 'otros', sin por ello perder su esencialidad, su eseidad, su libertad y autonomía; en el pensar andino se da a la inversa, es decir, el problema estriba en cómo pensar algo en su identidad no-relacional, cómo verle en su particularidad, fuera de los nexos que le constituyen. Por lo pronto, basta constatar que el modelo de racionalidad andino, como también el occidental, son las formas 'pre-lógicas' desde las que subyacen maneras de interpretar la realidad y el tiempo mismo, desde las cuales se ordena el sentido de realidad y por lo tanto sobre lo cual se cargan los sentidos ontológicos del 'mundo':

Por eso, puede ser llamada [la relacionalidad] el 'axioma inconsciente' de la filosofía andina y la clave pre-conceptual de la interpretación hermenéutica de la experiencia del runa/jaqi andino. Se expresa (entre otros) en algunos 
'axiomas derivados' o principios 'para-lógicos' andinos (...). Estos principios, a su vez, son base 'paradigmática' para un sinnúmero de fenómenos filosóficamente interesantes en los ámbitos de la naturaleza, la vida social y el orden ético (pp. 111-112).

Si lo que afirma el filósofo suizo-alemán en cuanto al papel que juega la pre-conceptual noción de 'relación' en el pensar andino, es cierto, ello obedece principalmente al hecho de que la racionalidad andina, en contraste con la occidental, no es una racionalidad 'racionalista', en cuanto en esta última opera como modelo de relacionamiento con la realidad un paradójico distanciamiento gnoseológico que privilegia la vista, por medio de la cual el sujeto se sitúa como 'objeto trascendente' y hace del objeto, meramente una imagen en el sujeto. De ello se desprende que la cultura occidental haya construido su racionalidad bajo la noción de la visión, al punto que la razón es la forma más adecuada de 'ver' la realidad, de allí incluso la noción de episteme como forma de 'ver'.

En contraste, el pensar andino en coherencia con la apertura al 'operador-seminal' del que habla Kusch (2009) o al axioma inconsciente y pre-conceptual que menciona Estermann (2006), privilegia otras facultades no visuales, otras formas, ya no de distanciamiento gnoseológico, sino de inmersión y acercamiento a la realidad, a lo que es.

Es en este mismo sentido que resulta sorprendentemente relevante la propuesta heideggeriana del Dasein, como oidor del ser, (Hören des Sein) y el ser mismo como revelado en el cuidado-inquietud (Sorge), pues parecen encontrar sentidos similares, pero más originarios, en la 'ontología-relacional' que subyace en la experiencia andina. Elementos que por demás poco profundizó la ontología occidental y que Heidegger apalabra en su primer Tratado de 1924, sobre el concepto del tiempo, cuando afirma que: El "estar-en" se manifestó como ocupación. Pero solo la explicación del carácter ontológico del "estar-en" mismo nos lleva a la originaria constitución del Dasein. El ser se revela en su estructura fundamental como cuidado (Heidegger, 2008, p. 43). 
El hecho de que es en el cuidado donde el ser se revela, ubica al Dasein con respecto a este -al ser- en una actitud no visual, no epistémica, a saber la de Hören, actitud que en sí misma es contemplativa-receptiva-abierta al ser, como cuando en el pensar popular andino se dice 'así son las cosas'; lo que muchos han interpretado como una mala resignación. En este mismo sentido comenta Estermann (2006), a pie de página, que el Hören heideggeriano comparte con el pensamiento andino el doble sentido de escuchar y obedecer: "La acepción de Heidegger (Hören des Sein) (...) hören o horchen ('escuchar') y gehorchen ('obedecer')" (p. 194) ${ }^{66}$.

Para el filósofo alemán, el “estar-en” era una característica ontológica del Dasein, entre otras ${ }^{67}$, que estaba mediada por el Sorge que el mismo filósofo ejemplifica con el trabajo, la entrega y el cuidado de un campesino a la tierra: "El estar-familiarizado incluye un fiarse del mundo, un entregarse al mundo sin reservas como cuando se cultiva y se trabaja, se aprovecha y se dispone la tierra" ((Heidegger, 2008, p. 43).

Ese entregarse al mundo sin reservas que caracteriza el Sorge en el estar-en del Dasein, donde el ser se manifiesta, no solo encuentra eco en la racionalidad andina, sino que es, como en el caso del 'operador seminal' kuschiano, un trascendente de la comprensión teórica, pues esta se funda siempre en una apertura previa al mundo, de allí que: "El estar-en-el-mundo es como tal un "abrir". Y este abrir no se realiza precisamente en términos de una aprehensión teorética. De hecho, la aprehensión teorética se funda ya en una apertura previa al mundo" (p. 44).

De manera semejante a la del Dasein como Hören, en su puro estar-en, la experiencia andina privilegia las facultades no visuales, ni teoréticas con respecto al mundo, sino principalmente afectivo-emocionales. De allí que en la lengua

66 Estermann también observa que en la filosofía tardía de Heidegger, dicha expresión adquiere un sentido de 'servidumbre' que se corresponde ontológicamente con: Seinsgeschick o 'hado del ser' (Estermann, 2006, p. 194).

67 Debe recordarse que para Heidegger son seis los caracteres ontológicos del Dasein, entre los cuales está el "estar-en”: "Los caracteres ontológicos del Dasein que hemos mostrado -tales como el estar-en, la convivencia, el hablar, la caída, el estar-descubierto, el ser-posible-, tienen que comprenderse como cooriginarios" (p. 109). 
quechua y aymara, abunden expresiones vinculadas a sentidos no visuales para referirse al conocimiento de la realidad, tales como: rikuy 'ver' ${ }^{68}$, uyariy 'escuchar', tupayuy 'tocar', mallikuy 'saborear', en contraste con las pocas expresiones que podrían hacer alusión a una operación o facultad intelectual, como: yuyuay o yuyakuy 'pensar' y 'recordar'.

(...) podemos constatar que el acceso privilegiado del ser humano andino a la 'realidad' no es la razón, sino una serie de capacidades no-racionales (que no son 'irracionales'), desde los sentidos clásicos, sentimientos y emociones, hasta relaciones cognoscitivas 'para-psicológicas' (...) El runa/jaqi 'siente' la realidad más que la 'conoce' o 'piensa'. La razón es una ayudante o un complemento que solo tiene 'razón' en la medida que el conocimiento adquirido pueda ser corroborado por las capacidades no-racionales (Estermann, 2006, p. 115).

Lo anterior somete a la razón, no al régimen de una negación o superación, como si se tratara de un determinado ascenso a la verdad, sino a la relacionalidad emocional que las cosas, aquello que es, adquieren en la experiencia vivida; de allí que la razón será siempre evaluada a la luz de capacidades no-racionales, sino relacionales, por ello se puede comprender también que la noción del tiempo en los Andes, esté vinculada con lo que hace que las cosas sean, y estas son dependiendo el tiempo propicio para ello o aquello. De tal suerte que el conocimiento de la realidad no es resultado de un esfuerzo de abstracción intelectual y menos aún de desintegrar lo que es en sus partes, a manera de la analítica, sino un integrar 'emocional'.

La racionalidad andina no tiene una concepción racionalista o empirista de las ciencias en el sentido de la episteme, objeto último del nous humano, sino que considera la 'ciencia' (el 'saber') como el conjunto de la sabiduría (sophia)

68 Estermann (2006), comenta que el verbo rikuy que puede ser traducido al español como 'ver', contiene un sufijo reflexivo, ' $k u$ ', que lo diferencia de la connotación que en Occidente tiene el verbo 'ver', pues dicho reflexivo indica que no se trata de una acción unidireccional, es decir, de un sujeto a un objeto. 
colectiva acumulada y trasmitida a través de las generaciones. Existe un 'saber' (yachay; yatiña) del subconsciente colectivo, transmitido por procesos subterráneos de enseñanza de una generación a otra en forma oral y actitudinal ('saber hacer'), mediante narraciones, cuentos, rituales, actos cúlticos y costumbres. Este 'saber' no es el resultado de un esfuerzo intelectual, sino el producto de una experiencia vivida amplia y meta-sensitiva (más Erlebnis que Erfahrung). Los verbos quechuas yachay y aimara yatiña no solo significan 'saber' y 'conocer', pero también 'experimentar' (...) (p. 119).

De la misma manera que el Dasein en su estar-en, es un 'oidor del ser' y está abierto al mundo, el pensar andino propone un 'vivir' el saber, como parte de un saber colectivo mayor, que siempre se expresa y manifiesta a través de rituales y ceremonias donde se sintetiza el sentido de lo que es real en el tiempo del encuentro comunitario.

Por supuesto que una racionalidad no-racionalista sino relacional tiene otros criterios de validez para juzgar aquello que es, y estos no siempre convergen con los criterios occidentales tan centrados en la distancia que permite el acceso epistémico, visual e instrumental de la realidad. Ello también supone que la tan en boga modernidad de Occidente, sea integrada de maneras particulares en la experiencia andina, de allí que: "Podemos hablar entonces no solamente de una 'ciencia andina' sui generis que no es una simple copia de la modernidad occidental. El runa/ jaqi andino no es 'pre-moderno', sino 'hetero-moderno"' (p. 120).

Ahora bien, no solo la 'ciencia andina', sino en general la racionalidad andina, es en extremo sui generis, pues en esta no se da propiamente una irracionalidad, sino otro modelo de racionalidad que visto desde una perspectiva no colonial del saber y de la filosofía, bien podría aportar a la dilucidación de una 'ontología actualizada -también sui generis- para la actualidad filosófica latinoamericana. Por su parte, para que la propuesta del pensar andino pueda ser comprendida por otras modalidades del pensar -en nuestro caso el occidental-logocéntrico- se hace menester ampliar el marco de lo que se considera racionalidad y sacarlo del encasillamiento occidental que la confinó a ser un mero ejercicio intelectivo y abstractivo, como también de lo que se puede considerar 'lógico' en el marco del conocimiento. 


\section{Una racionalidad relacional: la lógica andina}

Los hombres no comprenden que lo diferente concierta consigo mismo y que entre los contrarios haya una armonía recíproca, como la del arco y la lira (Heráclito, Fragmento 51: Barnes, 1991)

Como se ha mencionado, la racionalidad andina toma la relación, no propiamente como un accidente de la sustancia, sino como el nodo en el que las cosas son, es decir, el principio desde el cual se puede acceder al ser de las cosas está constituido por la relación misma, que tiene su 'equivalente homeomórfico' en la filosofía heideggeriana, en el concepto de Sorge. De allí que si se pudiera hablar de una 'ontología andina' -elemento contradictorio para no pocos intelectuales latinoamericanos- la relación sería el arjé, el 'mito fundacional' desde el cual se ordena todo un sentido de realidad, de 'verdad' y de 'lógica de la vida'. Ahora bien, que este sea un principio de orientación ontológico en el pensar andino, no supone de manera alguna que los sujetos andinos sean conscientes de la forma como su 'racionalidad', su 'logicidad' integra la relacionalidad; como tampoco lo está el sujeto occidental de su lógica logocéntrica, binaria y masculinizada.

Suponer una racionalidad no-racionalista, como también una 'lógica andina', sui generis por demás, de la que pueda devenir una ontología del tiempo andino, no es del todo problemático si se entiende esta en su sentido amplio; lo que implicaría no hablar de 'lógica', en singular, sino de 'lógicas' en plural. Ello supone también deconstruir el sentido colonial desde el cual Occidente hegemónico desplegó su lógica 'universalista y necesaria, en tanto 'invariante humano' y por lo tal trans-cultural o supra-cultural, para dar paso a una interpretación de la lógica vinculada a una racionalidad cultural, es decir, a una serie de principios y axiomas fundamentales que no siempre coinciden con la lógica racionalista desde la que la razón occidental desplegó su dominio epistémico sobre el mundo.

Si bien, la lógica parece haber sido campo exclusivo de la racionalidad occidental, al punto que desde esta se ha argumentado la validez 'universal' de su saber, ello no supone que sus principios lógicos sean supra-universales y que por 
lo tanto cualquier esfuerzo metafísico, ontológico y filosófico en América Latina deba estar ajustado a sus limitados parámetros axiomáticos. Por el contrario, y como se mostraba en la exposición del tiempo en la física occidental, los paradigmas de la física clásica newtoniana, como también de la geometría euclidiana, a la luz de la teoría de la relatividad, son obligados a abandonar su pretensión de universalidad supra-temporal, lo que hace razonable cuestionar también la racionalidad occidental como 'culturalmente determinada' y de relativo valor, o mejor de contextual valor.

La cuestión de la relatividad cultural de la lógica no es fácil de resolver (...). Los términos "racionalidad" y "lógica" tienen su Sitz im leben en la filosofía greco-occidental; pueden ser entendidos a cabalidad solo dentro de ese contexto cultural específico. Esto dificulta considerablemente hablar de 'lógicas no-occidentales' (...). De hecho que no vamos a poder encontrar ni un término quechua o aimara 'homeomórfico' al término de origen griego "lógica", ni una concepción bien definida que tuviera el mismo significado. Sin embargo, me parece justificado hablar de 'lógica andina', si no tomamos el término "lógica" en un sentido técnico y greco-céntrico, sino como un vocablo que indica la estructura básica de un cierto pensamiento. En el fondo se trata de 'racionalidad andina', pero en cuanto a sus principios básicos 'lógicos'. Cada pensamiento, cosmovisión, y hasta mito y fe tienen su 'lógica', una cierta forma intelectual regulativa (normatividad racional) que no tiene que ser necesariamente la forma occidental dianoética y bivalorada (Estermann, 2006, pp. 124-125).

Justamente, en este horizonte de comprensión es que puede hablarse de una 'lógica andina' que tiene como principio y eje articulador la 'relacionalidad'. Este principio afirma que "todo está de una manera u otra manera relacionado" (p. 126), vinculado con todo, lo que implica que el 'ente' no es la unidad básica, sino la relacionalidad misma. Pero esta relacionalidad no es la que se da como adición a la existencia de un ente particular con otro ente que configuraría un holon, en tanto 
red de interconexiones y relaciones, la racionalidad andina considera que la relacionalidad o la estructura relacional, es la que da 'entidad' a los 'entes'.

Si bien en la tradición filosófica occidental se pueden encontrar reflexiones que podrían ser 'equivalentes homeomórficos' del principio de relacionalidad andino, como es el caso de la ley de la proporcionalidad de Empédocles, la mónada leibniziana, la dialéctica hegeliana, el emanatismo neoplatónico o el Deus sive Natura de Spinoza, entre otros, el principio andino a diferencia de estos no permite llegar ni a un monismo donde la relacionalidad absorbe los relata en otra estructura anónima, ni tampoco supone la universalización de una dialéctica entre parte-todo, pues el 'todo andino' no es contradicción de las partes, sino la constitución de las mismas, es, como menciona Estermann a pie de página, un totum concretum: "La primordialidad de la estructura relacional no se entiende en sentido metafísico, ni cronológico, sino axiológico y vivencial” (p. 126).

Es decir, el 'todo' de la relacionalidad andina no es una totalidad analítica, un totum implicitum, sino concreto, explícito, y esa 'concretud' de la relacionalidad andina, tampoco es un segundo momento, un producto secundario de lo abstracto y universal como se ha dado en las versiones teístas e idealistas de Occidente: “En la filosofía andina, lo 'concreto' es la 'concreción' (con+creceré) de la realidad a través de la relacionalidad integral ('holística'): los 'entes' son concretos en la medida en que realmente son 'concrecidos', o sea: interrelacionados' (pp. 126-127).

De allí también que la realidad no es entendida como en la mayoría de los monismos, como un resultado necesario de una inferencia lógica, tal como se puede observar en el 'evidencialismo absoluto' de Spinoza, con su sistema deductivo de principios lógicos; de tal suerte que tampoco el principio de relacionalidad puede ser solo lógico e inferencial, pues en este se implican formas no-lógicas como la correspondencia en todos los aspectos de la vida, razón por la cual las relaciones 'lógicas' son secundarias, pues la relación primordial es la cósmica y solo si la primera se ajusta a esta tendrá sentido para el runa/jaqi andino.

Por otra parte la percepción de la relacionalidad occidental también se enmarca dentro de categorías como 'sustancia/accidente' donde el 'todo' es una sustancia 
o 'mónada', un 'mundo en sí', una sustancia espiritual individual; o en la versión hegeliana, un 'espíritu absoluto', un concepto en y para sí, sin embargo:

(...) la distinción entre 'accidentalidad' y 'sustancialidad' no es aplicable a la diferencia andina entre 'relacionalidad' y 'lo que se relaciona': la relacionalidad no es un aspecto exterior, posterior, causal o accidental de los relata, ni los relata son el producto del desenvolvimiento 'dialéctico' de una sustancia única, sea de naturaleza material o espiritual (p. 127).

Por demás, la idea de 'absoluto', de 'ente absoluto' no dice nada al pensamiento andino, pues para este no puede haber un 'ente' carente de relaciones y estas relaciones son 'trascendentes' y no 'inmanentes' y reflexivas como es común en la tradición occidental. De allí que incluso 'Dios' sea un 'ente relacionado' 'esencialmente' y no pueda ser entendido como un ser trascendente, no-relacionado, pues este lugar lo ocupa la relación misma; no existen seres ni entidades que sean su propio fundamento.

De tal modo que incluso el proyecto occidental moderno de un sujeto que se determina a sí mismo, que en tanto 'ente' es su propio arjé, no tenga equivalentes homeomórficos en el pensar andino que se viene enunciando: "El 'ser' más bien es el 'ser relacionado'; la 'ontología' andina siempre es una inter-ontología” (p. 128).

La totalidad de la realidad, vista desde el principio de la relacionalidad andina, se encuentra inmersa en una red de múltiples relaciones que se implican mutuamente. De allí que el indígena comprende que cuando algo en la 'economía' o la 'salud' anda mal, la solución no es propiamente el 'ente' enfermo, sino el sistema relacional en el que este está implicado, por lo que para 'equilibrar' aquello que está funcionando mal, 'desequilibradamente', es necesario restablecer las relaciones con la pacha como sistema y chakana relacional, y allí juegan un papel importante, nuevamente, la ritualidad, las ofrendas y los sacrificios.

La realidad como un 'todo' solo puede ser, en el conjunto de seres y acontecimientos que se interrelacionan; ello es claro en el registro lingüístico aymara y quechua, donde por ejemplo, en el caso de este último, el verbo quechua kay puede ser traducido como 'ser' y 'existir' y es usado para expresar relación de posición y 
pertenencia: “La equivocidad de kay (como 'ser' y 'tener') en quechua (y el sufijo posesivo aymara - ni-) indica que se trata de un verbo 'transitivo', es decir: el 'ser' es una 'relación' de tenencia o posesión" (p. 129). Ello indicaría, como lo señala Estermann, que: "Lo óntico es lo relacional, y lo ontológico es la 'racionalidad de la relacionalidad"' (p. 129).

Relacionalidad andina, entonces, no implica la inferencia lógica, ni la 'contigüidad' del monismo filosófico occidental, en el que no hay vacío entre los 'entes' y por lo tanto están implicados -principium plenitudinis-y menos aún la causalidad física que es solo uno de los modos de relación. En el pensar andino, la relacionalidad es 'esencial' pero no por ello 'necesaria'; aunque los 'entes' están implicados ónticamente, esencialmente, ello no implica que su relación sea 'necesaria' -que existe en todos los mundos posibles-. Esta característica de la racionalidad andina la compara Estermann con el juego de ajedrez: "Aunque las múltiples relaciones entre tablero y piezas son esencialmente normadas (como estructura de posibles movidas), las relaciones concretas (movidas ejecutadas) de ninguna manera obedecen a una necesidad" (p. 130). De tal suerte que la relacionalidad andina, de manera alguna puede considerarse como una expresión del determinismo monista con su 'principio de plenitud', máxime cuando "la estructura relacional andina tiene una cierta 'normatividad' (esencialidad) que, sin embargo, permite una gran variedad de concretizaciones" ( $\mathrm{p}, 130)^{69}$.

Ahora bien, esa 'gran variedad de concretizaciones' que se da en la relacionalidad andina, no conlleva, como en la perspectiva occidental, a un relativismo -paso del relacionismo al relativismo-, pues este todavía se enmarca en la perspectiva

69 Debe recordarse que el principium plenitudinis implica el determinismo, en tanto efectúa una inferencia lógica mediante la 'ley de la conversión de posibilidad en necesidad' y su contraposición lógica, así: "si todo lo posible $(\mathrm{Px})$ se realiza una vez (x), entonces todo lo que existe (x), necesariamente existe (Nx)" (p. 130). Al respecto, Lovejoy (1983), plantea que el 'principio de plenitud' es un axioma inconsciente en la mayoría de las posturas filosóficas de Occidente y tiene su actualidad en el actualismo lógico, donde la existencia del mundo actual niega la existencia de otros mundos posibles distintos al actual. 
de que de algo 'relacional' no puede haber un conocimiento 'absoluto'; supone por demás la capacidad que el logos, por medio de la 'inteligencia', la 'abstracción' y la cognición' es capaz de representar la realidad tal cual como esta es -este es el principio occidental de la connaturalidad-; sin embargo, ello es ajeno al pensar andino, pues para este, no es posible re-presentar la realidad por medios intelectivos, lógicos y abstractivos, sino por medio del símbolo y celebración: "La racionalidad andina no es 'representativa' (Abbildtheorie), sino 'celebrativo-simbólica'” (p. 132).

Otra particularidad de la relacionalidad andina, como principio lógico, es que esta no implica la inmanencia en ninguna de sus dos formas: idealismo y materialismo; como tampoco la yuxtaposición entre 'inmanencia' y 'trascendencia'. Por ejemplo, en el idealismo hegeliano, con su noción de un principio ideal, 'espíritu', que nunca es trascendido sino que al interior de este se da una dialéctica de 'momentos inmanentes', donde todo tipo de 'alteridad' o 'trascendencia' es absorbido 'aufgehoben', en el principio único 'espíritu absoluto'; también en la versión materialista se reduce la realidad a un conjunto de momentos 'materiales', que de la misma forma que en el idealismo, nunca pueden ser trascendidos, sino que se dan dentro de un principio único. En claro contraste con estas implicaciones de la relacionalidad en la filosofía occidental, en la relacionalidad andina:

(...) no se puede concebir la dualidad de idealismo y materialismo (ni de trascendencia e inmanencia) simplemente como una disyunción exclusiva. La filosofía andina es una posición más allá (o más acá) de esta disyuntiva, sin ser por esta razón una suerte de 'monismo neutral'. La relacionalidad andina no es 'totalidad' hegeliana, ni una 'trascendencia' levinasiana, pero tampoco una 'inmanencia' feuerbachiana” (Estermann, 2006, p. 133). (Énfasis nuestro).

Lo anterior tiene implicaciones de carácter ontológico y ‘teológico’ para la filosofía andina, y bien se refleja en la imposibilidad de pensar incluso a Dios como totalmente 'trascendente' y 'absoluto', pues: "Dios es inconcebible y hasta insignificativo para el runa/jaqi andino" (p. 133), si el tal es, de la única manera que puede serlo para Occidente: trascendente y necesario. Y lo es en tanto nada ni 
nadie puede ser totalmente trascendente, lo que no necesariamente implique que 'todo' sea inmanente -yuxtaposiciones en las que se mueva la razón occidental-; pues tampoco nada ni nadie puede ser totalmente inmanente, lo que en sí mismo parece transgredir el principio del tertium non datar, tan fundante de la razón occidental. De tal suerte que en los Andes, 'todo' lo que es parece ser trascendente e inmanente a la vez.

En el sentimiento común del ser humano andino, la 'inmanencia' tal vez tenga cierta predominancia, tanto en las relaciones interpersonales, éticas y ecológicas, como también cósmicas y religiosas. Dios es 'parte' de la 'realidad', más que una entidad más allá de ella; la otra persona es más 'parte' de la rede relacional y de la naturaleza que realmente 'otro'. Lo común y conmensurable domina sobre la alteridad y la inconmesurabilidad (p. 133).

Siguiendo la interpretación del pensar andino, otro de los elementos con los que se las tiene que ver la relacionalidad andina, en tanto principio lógico, es por una parte, el 'determinismo' y, por otra, el 'contigenismo'. Con este último parece la filosofía andina encontrar mayor afinidad, pues este piensa todos los acontecimientos como un factum que no está en manos del ser humano, ni siquiera como colectividad social, lo que en sí mismo puede ser interpretado como 'fatalismo andino', pues debe recordarse que en la tradición occidental el desarrollo histórico y humano es visto dentro del horizonte de 'separación' e 'independización' del sujeto de la naturaleza y todo lo divino. Sin embargo, el 'fatalismo' andino no se da de la misma forma que el necesarismo lógico-metafísico, ni el determinismo racionalista, pues en el pensar andino la idea de 'libertad', opuesta a la de 'determinación', es tan ajena como la yuxtaposición entre sujeto y objeto, por lo que la relacionalidad andina no presupone la 'diástasis' que subyace a todo el saber occidental. Por el contrario, el conocimiento es una experiencia, en la que el 'sujeto', tanto como el 'objeto' tienen su propia inteligencia, pues la realidad no es un 'dato bruto', sino que en sí misma tiene carácter cognoscitivo: "Para decirlo de manera paradójica (en categorías occidentales): la 'realidad' nos conoce en ella, y nosotros conocemos 
a la 'realidad' en nosotros; tanto 'sujeto' como 'objeto' poseen intelectualidad, o mejor dicho: sapiencialidad" (p. 135).

Como se observa, la relacionalidad andina, a más de ser el eje de toda la 'racionalidad', es también el principio lógico-ontológico, sui generis, desde el cual todo el aparato racional se organiza y desde el cual el tiempo mismo puede ser interpretado. De allí que resulte sumamente pertinente la lectura de la ontología que Maldonado (2007), basado en el filósofo lituano, Levinas, al comprender la 'relación' -con el 'otro'-, como previa a la ontología, ubica a esta última en un segundo momento de la relación.

(...) la ontología es un discurso que, cuando es tomado como fundamento o principio último, termina dando prioridad a un Ser anónimo, por encima de la relación entre subjetividad y otredad y de la relación social misma. En otras palabras, la ontología y la autenticidad del Dasein adquieren más importancia que el significado del momento trans-ontológico y la responsabilidad radical. Cuando la ontología se convierte en fundamental, la relación entre yo y otro se convierte en secundaria (...). Esto ocurre pues el ser debe su emergencia a un tipo de traición de la relación trans-ontológica (de donación y receptividad del sujeto al Otro) y, por tanto, tiende a hacer olvidar esa relación (...). Por eso el ser tiende a presentarse como fundamento de la realidad cuando no lo es (Estermann, 2006, pp. 151-152).

En un sentido menos subjetivizado, menos centrado en el sujeto como 'otro', sino en la realidad 'toda' como relación, es que la relacionalidad andina, justamente se comprende como la base, el soporte óntico, 'tras-óntico', de aquello que se puede decir que es.

De esta comprensión, sui generis, de la relacionalidad, se desglosan otros principios que el escritor de Filosofía andina, considera como 'derivados' o 'secundarios', pues estos están sujetos al papel que juegan en el marco general de la relacionalidad. Mientras la razón occidental considera la relacionalidad como algo secundario de la realidad, de allí que se relacione con conceptos como la connaturalidad, 
equivalencia e identidad; y de estas se deriven categorías como: identidad-diferencia, derivación-exclusión, en el pensamiento andino, se da la 'correspondencia'.

\section{Correspondencia andina, más allá de la causalidad occidental}

Cuando se habla de 'correspondencia', como uno de los principios derivados de la racionalidad andina, no se debe confundir ello con los paradigmas occidentales que en el campo de la física se expresan en la 'causalidad', pues si bien, 'causa-efecto', son un tipo de correspondencia, este no es el vínculo principal que denota la racionalidad andina. Por un lado, el principio de 'causa-efecto' en Occidente, parte del entendimiento de una actividad causal, y la pasividad por el otro; un principio activo y otro pasivo, como se ve en la methexis platónica, entre eidos y la 'cosa', que esta denota.

Correspondencia andina implica una relación de tipo bidireccional, entre diferentes partes o esferas de la realidad, mientras en la causalidad occidental, no hay tal bidireccionalidad, sino direccionalidad, lo que implica la jerarquía en una de las esferas de la relacionalidad. A pie de página, Estermann (2006), comenta que:

La metafísica clásica expresa esta 'correspondencia' básica de causa y efecto mediante una serie de axiomas:

a. Principio del ex-nihilo-nihil-fit [connaturalidad ontológica].

b. Principio de que nada es causa sui [causalidad intrínseca].

c. Principio de magnitud [cada causa es mayor que su efecto].

d. Principio de prioridad ontológica y temporal de la causa [prioridad].

Sin embargo se trata de características que subrayan la unidireccionalidad de la relación causal y excluyen a priori la bidireccionalidad (que es fundamental para la correspondencia) (Estermann, 2006, p. 137). (Énfasis nuestro).

En tensión con estas nociones de 'causa-efecto', el principio de correspondencia andino se aproxima más al isomorfismo cósmico de los pitagóricos, cuando se 
refieren a la relación entre lo mikron y lo makron, "tal en lo grande, tal en lo pequeño"; principio muy presente en las medicinas ancestrales, particularmente en la homeopatía que establece una relación de correspondencia entre la enfermedad y el medicamento, pues entiende que la pathia es causada por sustancias homeios -similares-, simile simile curator. El caso de la medicina, solo es un ejemplo que permite evidenciar la manera como se aborda la realidad desde los diferentes paradigmas del conocimiento. Mientras la ciencia occidental se ha hiperespecializado, diseccionando - literalmente- el cuerpo del ser humano, como la realidad misma, estas otras ciencias la comprenden como una totalidad orgánica-interrelacionada. De tal suerte que incluso en el campo cósmico hay una relación de correspondencia entre los astros y la psique en los cuerpos humanos, pero esta relación no es causal, sino de correspondencia simbólica.

El principio de 'correspondencia' pone en tela de juicio la validez universal del principio de causalidad (eficiente). No solamente a nivel de la relacionalidad humana, sino también en las relaciones 'físicas' entre diferentes estratos del cosmos, la causalidad es una de las múltiples formas de relación, pero de lejos la única y más destacable. La relación entre causa y efecto, a pesar de tener un nexo de 'eficiencia contigua', es una cierta forma de 'correspondencia': no puede haber un nexo causal entre dos relata totalmente inconmesurables (Estermann, 2006, p. 137).

$\mathrm{Al}$ respecto, y tal como se constataba en el primer capítulo de esta obra, la física contemporánea con los principios de indeterminación, de relatividad y de la misma teoría cuántica, ya cuestionan la validez universal de la física newtoniana, dando paso a un entendimiento de la fisis, donde hay una 'correspondencia' entre los fenómenos; entre onda y partícula, por ejemplo. Ello también supone un duro golpe para el determinismo del positivismo y el cientificismo que pretenden universalizar, cuantificar y matematizar la realidad 'toda'. En este mismo horizonte, y hablando de otro de los principios que derivan de la relacionalidad andina y del que nos ocuparemos más adelante, el de la 'complementariedad', el intelectual boliviano Javier Medina (2006), afirma: 
Esta idea de Complementariedad de los opuestos, formulada por Niels Bohr, es, ciertamente, el conocimiento más fecundo que ha traído consigo el Principio de incertidumbre de la Mecánica cuántica. Nos va a permitir corregir el mecanismo reduccionista del paradigma newtoniano que ha marcado a fuego la ciencia de la edad moderna (...). Esta idea de la unidad dual deriva de la inquietante constatación de la mecánica cuántica que el Electrón es, a la vez, Onda y Partícula. La bifurcación puede colapsar en una u otra posibilidad dependiendo del Efecto observador, con lo que el concepto moderno de "objetividad" empieza a estallar en cámara lenta, cambiando radicalmente nuestra visión del universo. La mente interactúa con la materia-energía, más allá de la escisión sujeto-objeto. No hay sujetos ni objetos; hay interacción, red, pautas; he aquí la inquietante nueva del nuevo paradigma. Las implicaciones atañen a todo y el cambio ya ha empezado (pp. 23-24).

Aquello que parece ser toda una novedad científica en la física actual: el principio de relatividad, de indeterminación, entre otros, ya ha sido parte de la sabiduría ancestral por milenios, no solo en los Andes, sino en Oriente y en gran parte del Occidente negado y subalterno, solo que en estos casos, dicho conocimiento no se ha expresado en términos matematizables, sino simbólicos, celebrativos y rituales, más cualitativos que cuantitativos. Ello ha supuesto desde la perspectiva de Occidente, la negación y subalternización de dichos saberes, que hoy la física contemporánea solo puede evidenciar abstractamente, razón por la que esta y no la otra, goza de credibilidad.

Este conocimiento cualitativo de lo 'real' en la filosofía andina, más allá de representarse en una analogía de proporción, como la usada por Platón en la Alegoría de la caverna, evidencia una relación simbólico-representativa con lo real, de allí que la naturaleza de la correspondencia andina, no pueda ser causal, inferencial o lógica, sino simbólica, es decir, representa lo real de manera densa y condensada: “La 'presencia simbólica' no es representación (cognoscitiva), sino una 'presentación' sui generis que tiene su propia lógica de eficacia no-causal" (Estermann, 2006, p. 138). 
La particularidad de la correspondencia andina se da entonces en todos los niveles de realidad -ello no implica su necesariedad, pues los nexos pueden ser múltiples, variados, inconstantes-, incluso en las esferas del espacio y el tiempo, tal como se evidenció en el segundo capítulo; existe correspondencia entre hanaq pacha y alax pacha, entre lo mikron y lo makron, entre hombre y mujer, sol y luna. En síntesis, la realidad 'toda', el tiempo y el espacio, todo lo que es, está-siendo como nodo relacional que tiene una co-respondencia que por lo enunciado tiene una validez 'universal', pues se expresa en todas las esferas de la vida.

\section{Deficiencia óntica y el principio de complementariedad}

La realidad, aquello que es, para el pensamiento andino se da como 'nodo relacional', y esta relación tiene un carácter de 'correspondencia', pero esta no de tipo causal, sino bidireccional, es decir, las dos parte o entidades se correlacionan, sin que una de estas sea necesariamente la 'causa activa' de la otra.

Por su parte, el principio de complementariedad, que en el campo de la física occidental ha sido estudiado por Niels Bohr, aporta a la interpretación ontológica del principio de correspondencia, del que ya se ha hecho mención. Dado que para la 'ontología' andina, ningún 'ente' puede ser sin una relación, en términos kuschianos, sin un estar-siendo, ello implica que 'nada' puede existir, ser, monádicamente, es decir, existe una relación complementaria entre los diversos 'entes'; de tal suerte que se puede hablar de una cierta 'deficiencia óntica' en los entes.

Dada la deficiencia óntica de los 'entes' en la ontología andina, se requiere de un principio que permita comprender la naturalidad de la relación en la que los 'entes' están-siendo y este principio es el de la complementariedad. La deficiencia 'óntica' de los entes es parcialmente superada en la relación de complementariedad, es decir, en aquello que permite al 'ente' hacerse pleno, con+plenus, completo; llegar a su plenitud óntica.

De manera similar, casi como un 'equivalente homeomórfico', la física contemporánea y su principio de complementariedad de opuestos comprende al electrón, en tanto 'ente', con sus dos propiedades 'complementarias': la partícula y la onda; 
en la complementariedad andina, lo que es, el 'electrón de la física', lo es, en tanto sus relaciones de complementariedad. En ambos casos -el andino y la física moderna-, no es posible hablar de un acceso al 'objetivo', a la realidad óntica, pues en uno, el de la física, solo puede ser interpretado por la abstracción matemática, y en el otro, por la simbólica-celebrativa andina; ambos por lo tanto superan la limitada concepción de 'objeto' como 'sustancia', también allí está su falta de 'objetividad', tan central para la modernidad científico-técnica.

El principio de complementariedad de opuestos: A y B son opuestos, pero se complementan en una relación contradictoria que los complementa al modo como jaqi integra chacha y warmi que son opuestos. Dicho cuánticamente, la materia-energía es continua y discontinua a la vez (...). El principio de complementariedad enlaza dos mediciones, la una que actualiza el acontecimiento en una homogeneidad: continuidad: onda, que Dominique Temple llama Palabra de unión y la otra, al contrario lo actualiza bajo la forma de una heterogeneidad de singularidades: discontinuidad: partícula, que Temple llama Palabra de oposición (Medina, 2006, p. 15).

Esta lógica de la complementariedad de opuestos y su similitud con el pensamiento cuántico y la física moderna, ha sido evidenciada por la mayoría de estudiosos del pensamiento andino, quienes no necesariamente concuerdan en sus enfoques, abordajes y propuestas. ${ }^{70}$ Uno de estos enfoques lo ejemplifica el trabajo de Fernando Montes (1999), quien desde una perspectiva más sicoanalítica que filosófica, ofrece un extenso y riguroso estudio sobre las narrativas y mitologías andinas, evidenciando en estas, cierta lógica de complementariedad de opuestos que se repite de manera arquetípica y que tiene su equivalente homeomórfico en Occidente, en los registros de la física y la ciencia moderna. Al respecto, una extensa cita de La Máscara de piedra (1999), podrá ilustrar los vínculos entre algunos abordajes científicos modernos y la sabiduría popular andina:

70 Ver: Estermann, 2006, 2009; Medina, 2006; Montes, 1999; y Kusch, 2006. 
En los sistemas físicos macroscópicos predomina el caos o principio de entropía, en los sistemas biológicos prevalece el orden o principio de negaentropía, y en los sistemas subatómicos (y también en los sistemas psíquicos) predominan simultáneamente los dos principios, en una unidad contradictoria virtual. Así, en el núcleo del átomo hay una fuerza atractiva (la fuerza fuerte) que mantiene las partículas unidas entre sí, y que al ser liberada desencadena la energía nuclear. A esta fuerza unificadora se le opone otra fuerza separadora igualmente poderosa (el principio de exclusión de Paulini), que impide que las partículas se agolpen y desaparezcan en un solo punto (...). Otro ejemplo subatómico es la dualidad partícula-onda (...) (Principio de indeterminación de Heisemberg) (p. 158).

Ahora bien, la complementariedad de los opuestos, que por demás se deja entrever en la literatura y los dibujos de Pachacuti y Guamán Poma, no se da de la misma forma que el Aufhenbung hegeliano, donde 'C', excluye las diferencias complementarias entre 'A' y 'B'. Es decir, en la complementariedad andina, el principio lógico occidental del tertii non datur o tercero excluido, se transforma a su contrario, al 'principio del tercero incluido', pues: “existe una tercera posibilidad más allá de la relación contradictoria: la relación complementaria, justamente, que es un estado particular de potencialidades coexistentes simétricas y contradictoras en sí mismas" (p. 158).

En otro nivel, un posible equivalente homeomórfico de este principio andino se puede observar en el hilemorfismo aristotélico y su idea de deuteré ousia, 'ente' o 'sustancia individual', la cual requiere para ser tal, la coexistencia de dos principios complementarios: materia y forma. La materia sin la forma, y la forma sin materia, no puede ser 'ente'. En el caso de la filosofía andina, Estermann (2006), recuerda que esta llega a un nivel ontológico más elevado que el hilemorfismo, pues: “(...) también esta 'sustancia individual' aristotélica a su vez es 'incompleta' y requiere su complemento para llegar a ser un ente concreto (concrecere), con un cierto grado de 'sub-sistencia"' (p. 139).

Ahora bien, en la filosofía andina el 'ente' puede convertirse en un totum en el conjunto con su complemento, por ello comprende que 'la parte', únicamente 
en relación complementaria con otra 'parte', puede integrar una entidad. Sin embargo, lo 'concreto', en la tradición occidental, ha sido interpretado como lo 'particular', muy en contra de su etimología literal. De allí también el hecho de que la 'contraparte' de una 'parte', sea vista como 'contrapuesto' y no como complemento imprescindible.

Desde la perspectiva de la lógica formal, la contradicción es explicada mediante el "principio de no-contradicción", el cual afirma que una proposición no puede ser verdadera y falsa a la misma vez y en el mismo sentido [-P ( $q$ \& -q)]; en términos ontológicos, un ente no existir y no existir, como tampoco ser otro ente al mismo tiempo.

Las consecuencias lógicas, ontológicas, éticas y epistémicas de una racionalidad soportada sobre el principium contradictionis, que a su vez contiene el principium identitatis, el cual enfatiza la conciencia del 'ente' consigo mismo y su no-identidad con otro; como también el principium tertii non datar o 'tercer excluido', conforman el repertorio de una racionalidad excluyente y bivalorada que se desplegó como modelo colonial del saber y como única alternativa para la explicación ontológica.

El principio de complementariedad enfatiza la inclusión de los 'opuestos' complementarios en un 'ente' completo e integral. Tertium datur: existe una tercera posibilidad más allá de la relación contradictoria, o sea: la relación complementaria. Un 'ente', acontecimiento, sentimiento o pensamiento como entidad integral es este 'tercio' como síntesis de algo (posición) y de su 'opuesto' (contra-posición) (...) el pensamiento inclusivo (...) considera la 'contradicción' (Widerspruch) como una 'contraposición' (Gegensatz) de dos 'posiciones' incluida e integradas en un 'todo' que contiene los 'complementos' particulares y parciales (Estermann, 2006, p. 141).

La contradicción (Widerspruch), vista desde la perspectiva del principio de complementariedad andino, opera con unas particularidades 'lógicas' -'sóficas'- que posibilitan otros accesos ontológicos y filosóficos a la realidad. Lo que para Occidente es una 'contradicción formal' que implica la exclusión de una de las partes (A excluye a B y viceversa); que tiene sus consecuencias en la ontología 
colonial, donde para ser, se requiere que el otro no sea -oposición entre el Dasein y el damné-, para la filosofía andina es una 'contrariedad material', pues aunque A y B son distintos, pueden coexistir como partes complementarias de una tercera entidad, de un 'ente' total. En otras palabras, la 'contrariedad' es justamente el 'punto cero' entre la identidad plena $(\mathrm{A}=\mathrm{A})$ y la contradicción (A \& -A), es el 'tercer' excluido de la lógica occidental: aquello que no-puede-ser para esta, el 'tercer', es ciertamente lo que es para la filosofía andina ${ }^{71}$.

Esta consecuencia del 'tercer incluido' de la complementariedad andina, sale a la luz con toda claridad, y se grafica a la perfección en el Altar de Coricancha del que se ha hecho mención anteriormente para referir a la espacialidad andina. Las contraposiciones entre hombre-mujer, sol-luna, derecha-izquierda, no son excluyentes en manera alguna, por el contrario, son interpretadas como complemento óntico para la formación de una entidad integral, de allí que Estermann, afirme que:

El principio de complementariedad se manifiesta a todo nivel y en todos los ámbitos de la vida, tanto en las dimensiones cósmicas, antropológicas, como éticas y sociales. El ideal andino no es el 'extremo', uno de dos 'opuestos', sino la integración armoniosa de los dos (Estermann, 2006, p. 142).

Esta idea de 'integración armoniosa', no es propiamente el mesotes o 'medio', entre dos extremos, como lo propone la idea de la 'virtud' aristotélica. Se relaciona más con la idea del oxímoron, (ỏ łú $\omega_{\omega \rho} \rho v$ ), heraclitiano, y su concepción del 'ente' como unión de los opuestos; en general, dicha 'integración armoniosa' del principio

71 Ahora bien, esta complementariedad andina no es 're-presentable' conceptualmente, ni lógicamente, como en el caso occidental. Tampoco como en el registro de la filosofía china, donde la complementariedad es 'asible' por medio de la meditación y la mística, sino que principalmente se manifiesta a través de la ritualidad-celebrativa "las posiciones complementarias llegan realmente a complementarse (integrarse) en y a través del ritual celebrativo, mediante un proceso 'pragmático' (acción) de integración simbólica" (Estermann, 2006, p. 142). 
de complementariedad andina, encuentra en la dialéctica heraclitiana un posible equivalente homeomórfico, pero siempre limitado para expresar la manera sui generis de la ontología andina.

\section{Complementariedad y dialéctica andina}

Como se evidenció en el segundo capítulo, particularmente en la descripción del tiempo-espacio andino en el Altar de Coricancha, salta a la vista la importancia ontológica que tiene la dialéctica, en todo el sistema racional andino. La cercanía de la dialéctica andina con la dialéctica occidental ha sido observada en los análisis de los más representativos estudios de la sabiduría aimara (Medina, 2006; Estermann; 2006; Montes, 1999), de allí la importancia de retomar algunos elementos que pueden evidenciar la forma particular como la dialéctica andina, funciona dentro de todo el sistema de racionalidad-relacional.

Este dualismo andino no solo es constatable en la lógica andina que se ha descrito a lo largo del hilo argumentativo que se ha propuesto en esta obra, sino también en múltiples indicaciones fenoménicas de la realidad andina. Por ejemplo, Juan de Santa Cruz Pachacuti en su dibujo del Altar de Coricancha, ubica los objetos en una relación dual-complementaria: alto-bajo, sol-luna, hombre-mujer; las narrativas mitológicas como: Pachakamaq, Tunupa, los Hermanos Ayar, son también registros culturales que evidencian una dialéctica constante en la racionalidad andina (Montes, 1999); como también se da en la propuesta del Suma Qamaña o 'Buen Vivir' (Medina, 2006).

Ahora bien, una de las primeras diferencias que subyace al dualismo andino con respecto al occidental, en sus dos versiones: materialista e idealista, es que en la filosofía occidental parece ser un determinante ontológico la idea de un cierto logos que subyace entre posiciones antagónicas a través de las cuales emerge dicho logos, es decir, aquello que es.

Por su parte, Montes (1999), considera que el sentido de la dialéctica andina toma la contradicción como dinamización y posibilidad, pues los 'opuestos' complementarios se integran, se sintetizan. Sin embargo, ninguno de los términos 
o 'entes' de la relación dialéctica es 'eliminado', sino que ambos prevalecen en una alternancia entre los opuestos. De tal manera que podría pensarse que en un primer momento de esta dialéctica andina uno de los 'polos' de la dualidad predomina; en términos escolásticos, se da en acto, mientras el segundo está en potencia, es subordinado al primero.

Un segundo momento de la dialéctica andina, supondría que los dos términos 'encuentran un estado intermedio', es decir, cuando son acto y potencia a la vez, punto donde hay equilibrio entre las fuerzas 'antagónicas'; tal como sucede en la idea de la chakana como puente. Un tercer momento supondría la actualización, la realización, la puesta en acto, del segundo término, pero paradójicamente 'potencializado' por el primero:

Esto es posible porque cada término potencializa a su opuesto, y al enfrentarse los dos y estar igualados en un tenso equilibrio de fuerzas contrapuestas, ambos hallan en un ser y no ser: una tercera posibilidad que niega y afirma a la vez (p. 157).

En primer lugar, las posiciones 'antagónicas' en la dialéctica andina, son de carácter complementario y no excluyente, es decir, el 'antagonismo no es 'irreconciliación racional', pues "se requieren mutuamente, no como 'motor dinámico' para elevarse a otro nivel, sino para complementarse en el mismo nivel" (Estermann, 2006, p. 144). Esta misma diferenciación con la dialéctica hegeliana, la constata Montes (1999), cuando afirma que:

La diferencia con la lógica andina estriba en que la síntesis hegeliana no es propiamente un equilibrio contradictorio unificador entre tesis y antítesis, sino que en ella uno de los opuestos predomina sobre el otro. Además la síntesis se transforma en una nueva tesis, a la que se le opone otra antítesis, y ambas constituye[n] una posición cualitativamente distinta de la original, dando lugar a una secuencia de transformaciones lineales abiertas al futuro (p. 159). 
Aquello que Montes denomina "transformaciones lineales abiertas al futuro", es justamente donde radica otro de los elementos fundamentales que no permite confundir estas dos versiones de la dialéctica, pues por demás, dicha 'progresividad' de la dialéctica hegeliana, tiene serios impactos en las consideraciones ontológicas en torno al tiempo, como se observará en el abordaje del Suma Qamaña andino. En síntesis, se podría afirmar que mientras la dialéctica hegeliana es progresiva, producto entre otros elementos de una noción escatológico-cristiana del tiempo, la andina es 'estática' y en muchos casos cíclica.

Este 'estaticismo andino' se debe a que las oposiciones entre las partes complementarias, se resuelven, se completan, tienen su plenitud, su concreción óntica, en una unidad, un totum siempre contradictorio y equilibrado:

Aquí, las contradicciones surgen, se disipan y resurgen alternativamente, en infinita periodicidad cíclica que siempre retorna al punto de partida, asegurando así la inmutabilidad del sistema. Si bien la asimetría y la búsqueda de equilibrio imprimen una cierta dinámica al paradigma andino (...) (p. 159).

Ello supone que la complementariedad andina no es el resultado de un proceso dialéctico, sino que es la expresión dialéctica de la relacionalidad que subyace en la racionalidad andina. Tal como Montes lo constató, al percatarse de cierta 'dinámica' en la dialéctica andina, esta para el alemán no se da por medio de un proceso 'sintético', sino por medio de la transformación de las entidades, es decir: "un cambio de relaciones dentro del marco a priori (trascendental) de la relacionalidad" (p. 145).

Para la dialéctica occidental son imprescindibles los presupuestos de la 'universalidad' y 'progresividad', por lo que es inconcebible la reversibilidad de la dinámica, pues esta apunta siempre a una superación que conserva (Aufhenbung), como un 
ideal, un utopos, muchas veces conceptual, otras lógico, social o religioso ${ }^{72}$. Sin embargo: “(...) La filosofía andina no comparte ni la progresividad, ni la unidireccionalidad de la historia y del proceso cósmico. Defiende una suerte de ciclicidad periódica que quizá también haya sostenido Heráclito (en continuación creativa con Empédocles)" (pp. 144-145) 73 .

Estermann considera que de estos principios ontológicos de la relacionalidad andina, particularmente de las implicaciones de la correspondencia en el principio de complementariedad, se desprende el principio de la reciprocidad, el cual se expresa en un campo más pragmático y ético que ontológico.

Este principio es básicamente la consecuencia ética, política y económica de la relacionalidad andina. De la misma forma que en el Altar de Coricancha cada parte del altar tiene su tensa correspondencia y complementariedad, los actos

72 En el caso de una versión 'autóctona' de esta dinámica que tiende a un Aufhenbung, en América Latina, se da el caso de la producción de Vasconcelos, cuando refiriéndose a la Raza cósmica, afirma: "En la historia no hay retornos, porque toda ella es transformación y novedad. Ninguna raza vuelve (...). El indio no tiene otra puerta hacia el porvenir que la puerta de la cultura moderna, ni otro camino que el camino ya desbrozado de la civilización latina” (Vasconcelos, 1990, p. 25).

73 Para el intelectual peruano Mario Mejía Huamán, es un equívoco suponer la periodicidad y ciclicidad del tiempo andino. Por el contrario, el intelectual considera que la arquitectura andina muestra una noción del tiempo lineal y progresiva, que pone en evidencia un proyectarse y trascender del hombre andino: "En primer lugar, si la concepción del tiempo y la historia en la concepción andina pre-colombina, hubieran sido cíclicos y circulares, los andinos habrían creído en la reencarnación (...). Creemos que, donde no es posible concebir que el hombre y la sociedad van en progreso y desarrollo, caben toda clase de concepciones pesimistas, escépticas, nihilistas o agnósticas, cosa que no se dio en los Andes. Aún es posible hoy, contemplar no muy lejos del Cusco, la canalización del río Watanayo las calles Hatun Rumiyoqy Choqe Chaka (...). Nadie que es pesimista o tiene terror a la historia como ya señalamos, podría construir obras tan maravillosas (...) no habrían podido construir, como repetimos las grandes obras de arquitectura que hoy son la admiración y el patrimonio del mundo, las mismas que son un proyectarse del hombre hacia la eternidad" (Mejía, 1999, pp. 67-68). 
del runa/jaqi responden a ese mismo criterio, ahora a manera de retribución complementaria.

A diferencia de la conciencia occidental, la reciprocidad andina no requiere de un 'sujeto libre', mayor de edad e independiente, sino más de un 'deber cósmico' que es el símbolo de un orden universal del que el runa/jaqi, es solo una parte. De allí que los diferentes actos se interrelacionan, de la misma manera que el 'ente' es, solo como nudo-relación. Esta misma reciprocidad funciona también en el ámbito de lo económico, donde no necesariamente la cuantificación de los productos es el factor decisivo, pues:

(...) Puede haber otros factores más importantes: el parentesco de las personas que intercambian; la necesidad vital; la escasez del producto; las características de las personas. El trueque no se realiza a ciegas, tal como lo hace supuestamente la 'mano invisible' del mercado monetarizado. El anonimato y la abstracción (cuantitativos) del dinero (pecunia non olet) se vuelven directos y concretos (cualitativos) en el trueque recíproco de bienes (Estermann, 2006, p. 147).

La reciprocidad es justamente la forma como los seres humanos pueden establecer el equilibrio cósmico, y ello es una consecuencia lógica de una perspectiva que es ontológicamente relacional, es decir, que es resultado de los nexos relacionales en todos los ámbitos de la existencia, del ser-estar. De allí que cualquier acción que no tenga una correspondencia, puede alterar el orden cósmico, el sistema relacional en el que las cosas son. Ello nuevamente toma distancia del principio occidental de la causalidad, pues en este, la acción, como ya se mencionó, es unidireccional, mientras para la filosofía andina la causalidad es entendida como 'momento' de una relacionalidad de carácter recíproco. De allí que: "El equilibrio cósmico (armonía) requiere de la reciprocidad de las acciones y la complementariedad de las y los actores/as" (p. 147). 


\section{Una racionalidad de la relación: la prioridad ontológica de la chakana andina}

Los principios lógicos que rigen la racionalidad andina se soportan en la relacionalidad, en la existencia de nexos en todos los ámbitos de la realidad. Sin estos principios lógicos o meramente aplicando los paradigmas occidentales bajos los cuales reposa todo un cuerpo doctrinal de la ontología, y particularmente del tiempo-espacio occidental, es incomprensible el acercamiento del tiempo realizado en el segundo capítulo de la obra; por demás podría parecer desde una perspectiva ortodoxa, un abordaje nofilosófico. Allí se observaba la manera como, por ejemplo, Juan de Santa Cruz Pachacuti, en su dibujo del Altar de Coricancha, se esfuerza por expresar, seguramente de manera inconsciente, la lógica de la relacionalidad que se han dilucidado en el presente capítulo. Cada esfera de la espacialidad descrita en el obra pictórica del yamqui, cada entidad, está asociada con los ejes de la complementariedad, de derecha a izquierda, y con la correspondencia. De tal suerte que el sol en el altar, tiene su dialéctica complementaria en la luna, cómo el 'mundo de arriba' se corresponde de manera recíproca con el mundo de abajo; en el centro se da el espacio tiempo del 'aquí, del aka pacha, espacio-tiempo que no es otra cosa que la intersección, el cruce de las múltiples formas de la realidad, el nudo relacional, de donde emerge aquello que está-siendo.

Uno de los principales problemas que encuentra la filosofía occidental para comprender el paradigma racional-relacional de la filosofía andina, es que esta parte de a prioris lógicos soportados sobre los principios de no contradicción y del tercero excluido. Justamente la idea de la chakana, como nodo relacional, espacio-temporal de las entidades o relatas, es el que más puede resultar problemático para el principio del tercer excluido que se soporta en la idea de "campos ontológicos separados, desligados"; ello principalmente porque la chakana es justamente el tertium excluido de dicho principio lógico. 
Para la filosofía andina (en especial la pachasofía), el 'puente' (chakana) tiene, en cierto sentido, 'prioridad ontológica' con respecto a los extremos conectados o relacionados (relata relationem supponut); la relación tiene, para hablar en lengua occidental, dignidad ontológica, respectivamente ontomorfa. Por su 'lugar' (topos) trascendental en la estratificación pachasófica (Estermann, 2006, p. 181).

Retomando el dibujo de Pachacuti (Anexo 1), son identificables los fenómenos de transición los que en términos de Occidente son los 'trascendentales'. Sin embargo, ha de entenderse que en términos estrictos, los 'puentes' no son propiamente entidades 'sustanciales', 'entes', sino nodos relacionales. Así, en el Altar de Coricancha se advierte la relacionalidad de las coordenadas por medio de elementos chakánicos, que señalan: por un lado, en la posición vertical se dan las relaciones de correspondencia; y en la posición horizontal, las de complementariedad. Las coordenadas conectan las 'entidades' espacio-temporales del kay/aka pacha, con el hanaq/alax pacha, y los elementos 'femeninos' con su complemento relacional 'masculino'. En el dibujo de Pachacuti, tomándolo como la representación del cosmos, en tanto totalidad de lo existente, es decir, como pacha, aparece lo que Estermann ha denominado una chakana cósmica, la kuka mama o madre coca, la cual tiene un significado simbólico, es decir, no es de carácter racional, lógico, ni tampoco mitológico-representativo, como se ha pretendido abordar “(...) la coca en cierto sentido puede ser llamada el 'ombligo del universo' (...) porque concentra en forma simbólico-celebrativa y hasta 'mística' a toda la $p a-$ cha, a todo el cosmos" (p. 181).

Esto es entendible dado que la kuka mama para el runa/jaqi, es en verdad un real symbol de la pacha como totalidad, en tanto que pone en contacto las esferas de lo 'alto', lugar de los apus y el aka/kay pacha, lugar del runa/jaqi; pero también tiene una relación temporal, pues 'conecta' con los antepasados, lo que permite entrever mejor el presente y el futuro. De tal suerte que la coca es más que una 'entidad sustancial', un alimento, es un medio ritual e interpretativo que condensa el sentido de la pacha, pues como símbolo, con sus tres hojas, representa la relacionalidad 
originaria de todo el universo; en el dibujo del yamqui, conecta respectivamente el alax, aka y manqha pacha ${ }^{74}$. Así las cosas, la coca es el símbolo de la unidad del cosmos, pero no se ha de confundir el símbolo -coca-, con lo simbolizado, que es la relación misma, la chakana. Sin embargo, tampoco es meramente un 'símbolo' en el sentido de un significante, pues ella misma también es lo que es simbolizado: "La coca es un 'puente' ritual-celebrativo, y por tanto, un canal importante de conocimiento" (p. 183).

Si la mama kuka, funciona como un canal importante de conocimiento, y en consecuencia como 'puente', se debe principalmente a que la filosofía andina no tiene una visión restringida que limita el conocimiento a aspectos sensitivos e intelectuales, sino que el 'conocer', es la realización simbólico-celebrativa de aquello que se pretende conocer: "En y a través del ritual, se 'presenta' el conocimiento que no es un 'deposito' de la persona, sino una relación intrínseca del plan cósmico" (p.183).

74 Es interesante que términos rituales, el kuka uñiri andino, el 'adivinador de la coca', inicia generalmente su rito esparciendo la coca en un altar rectangular que representa el universo, para poder leer la 'suerte' o destino del mundo, de la comunidad o de quien solicite sus servicios. Así, el kuka uñiri busca por medio de la coca esparcida, relacionar las diferentes dimensiones espacio-temporales de la realidad: el pasado con el presente y el futuro. 
Conclusiones 



\section{Excurso: tiempo andino, Suma Qamaña y desarrollo occidental}

Poco ortodoxo podría parecer terminar estas reflexiones sobre ontología y tiempo, precisando cierta 'materialidad', cierta vivencialidad del 'fenómeno-relacional' del tiempo en las dinámicas que se imprimen como praxis sociales, éticas y económicas; es decir, en la estética y poiética de la vida cotidiana. Por una parte, el pensar las 'consecuencias' de la ontología del tiempo-espacio andino en las dinámicas de la vida cotidiana, en la praxis política, económica y material, podría desbordar no solo las delimitaciones propias de un proceso investigativo como el que se ha propuesto a lo largo de estas páginas, sino que también a de reconocerse que desde otros campos disciplinares de las ciencias sociales, ello podría ser mejor dimensionado y abordado. Tarea que de ninguna manera es 'menos digna' que la filosófica, pero que ciertamente al margen de la dilucidación ontológico-filosófica resultaría superficial, precaria y estéril.

Las dinámicas del tiempo-espacio occidentales esbozadas en el primer capítulo, dejan ver solo una de las formas cómo la racionalidad occidental ha pensado el fenómeno del tiempo, pues ciertamente pretender hablar del 'tiempo occidental', como si ello fuera un marco homogéneo y continuo, no sería sino arrogancia filosófica, más que una ingenuidad. Máxime tratándose de dos abordajes que en 
apariencia están a una distancia procedimental y de perspectiva -la física moderna y el existencialismo heideggeriano-. De allí que de cara a estas reflexiones, es necesario preguntarse por la actualización, por las consecuencias contemporáneas del tiempo y no solo por los abordajes que del mismo se han dado: ¿cuáles son las características del tiempo en la actualidad occidental?, ¿cómo reflejan estos los principios lógicos y ontológicos en que se soportan?, ¿cuáles son las alternativas que la ontología del tiempo andino da para el mundo contemporáneo?

La dinámica de la globalización neoliberal en la actualidad, tanto como en antaño la colonización del Abya Yala por los europeos, ha estado caracterizada por la imposición de una determinada lógica del tiempo y en consecuencia de una ontología que le es propia; ambas comparten una noción del tiempo que tiene sus orígenes en la tradición judeocristiana y que por vía del catolicismo, en el sur, como del protestantismo, en el norte, se introyectó sobre la realidad americana desplegando sus teleologías e utopías que marcan las dinámicas del continente, constituyendo una materialidad particular.

Siguiendo la perspectiva de Estermann, la concepción hegemónica del tiempo occidental es resultado del encuentro de la tradición semita con la greco-romana, y es justamente el cristianismo la 'síntesis' entre estas dos, de allí también la aparente universalidad de la que goza esta particular perspectiva.

La perspectiva semita ${ }^{75}$ del tiempo se caracteriza por no ser de carácter cuantitativo, sino cualitativo y simbólico. Sin embargo, esta característica no se ha de confundir, como si fuera un equivalente homeomórfico de la noción andina, pues para el hebreo, tanto como para el árabe, la historicidad de los acontecimientos en el tiempo es imprescindible, pues es allí donde Yahvé, Alá, salen al encuentro del hombre. De allí también que ciertos acontecimientos históricos cobren relevancia

75 Los semitas son un conjunto de pueblos que comparten un mismo origen lingüístico y que se establecieron en Mesopotamia y Oriente Próximo. Los pueblos semitas son los acadios, los amonitas, los arameos, los árabes, los etíopes y los hebreos. 
simbólica, en tanto el encuentro entre lo 'trascendente' y lo 'inmanente', como paradigma arquetípico del devenir social e individual.

A ello se suma una perspectiva progresiva del tiempo que se debe a una comprensión escatológica, es decir, una comprensión de que el tiempo 'se mueve para adelante' y que la historia se desarrolla ascendentemente, de condiciones peores a mejores; hasta una cierta 'plenitud' de la manifestación de la deidad en las dinámicas de la historia.

Esta concepción incluye el elemento de progresividad, tan presente en la concepción occidental dominante de nuestros días. El tiempo en sentido semita es prácticamente el proceso histórico de un punto de inicio absoluto (alfa) a un punto final (omega), de (...) la Creación (protología) hasta el Juicio Final (escatología). Fuera de este proceso y acompañándolo, solo existe Dios trascendente y eterno, creador no solo del espacio sino también del tiempo (Estermann, 2008, p. 122).

De tal suerte que el tiempo es el escenario del drama de la Salvación, del encuentro de lo 'trascendente' con lo 'inmanente', de allí la tendencia unidireccional e irreversible del tiempo semita, donde cada instante, cada momento histórico, es parte de todo el proyecto de la deidad que apunta a una plenitud mesiánica.

En contraste con la tradición del tiempo semita, la concepción griega, como se ha mencionado en páginas anteriores, tiende a la 'ciclicidad eterna', al 'eterno retorno. Si bien, parecen encontrarse en algunos puntos el tiempo griego con el andino, este último a diferencia del primero no establece una asimetría entre aquello que está y se da en el tiempo, es decir, lo material, pasajero, accidental, mundano, y lo que es atemporal, que está por 'encima del tiempo', lo eterno, divino y esencial; de allí también cierto carácter negativo del tiempo en esta concepción: “Lo temporal pertenece al reino de lo material y carece entonces de 'verdad' y 'realidad' en sentido estricto" (p. 123). Ello puede explicar el hecho de la poca importancia que la filosofía antigua prestó a la historia y al desarrollo socio-político, por supuesto con marcadas acepciones como lo es el caso de Aristóteles. Sin embargo: 
A pesar de que Aristóteles abogara por el valor de la experiencia, su lógica y ontología relativizan este contigenismo (...). En el fondo, las filosofías griega y romana de la Antigüedad están marcadas por una fuerte tendencia determinista y anti-histórica (p. 123).

La 'circularidad' del tiempo greco-romano expresa la idea del 'eterno retorno' y en este se encierra toda posibilidad de la realidad, de allí el carácter determinista de esta perspectiva. Ello justamente tuvo su expresión ontológica en el principio de plenitud y de evidencia, donde "todo lo que pasa, necesariamente pasa", pues según el principio de plenitud el universo está 'lleno', lo que tiene como consecuencia que la idea de que cada posibilidad se realiza 'necesariamente' una vez; de allí que el principio de evidencia considere que hay una correspondencia -no al estilo andino, precisamente- entre ser y conocer, de tal manera que 'todo' lo conocido existe. Ambos principios señalan una equivalencia entre necesidad, existencia y posibilidad.

Dado lo anterior, es entendible el hecho de que la razón occidental sea especialmente sustancial, rechazando lo accidental, lo individual y novedoso, pues pone su acento en lo necesario, permanente y 'eterno'; por ello el tiempo es movimiento perfectamente cíclico, lo que se constituye en metáfora de la idea de eternidad.

La síntesis de la noción semita y greco-romana del tiempo se puede observar en las dinámicas del tiempo contemporáneo. Este toma del tiempo semita la centralidad de la historicidad de lo real, como también la progresividad y unidireccionalidad del tiempo y esto se deja entrever especialmente en la tendencia escatológica de las múltiples utopías -escatologías seculares- occidentales como el socialismo, el marxismo, el liberalismo y, en el particular en el neoliberalismo con su utopía, que muchas veces se presenta como anti-utopía (Hinkelammert, 1984), de 'progreso infinito' y del 'mercado total'. Por su parte de las nociones greco-romanas parece, el tiempo 'globalizado', haber tomado la subalternización de lo material, lo temporal y mundano. 
Ahora bien, la concepción moderna del tiempo también tomó distancia de, por ejemplo, la ciclicidad del tiempo griego, como del trasfondo religioso de la tradición semita. Sin embargo, es importante recordar que el neoliberalismo tiene expresiones de carácter religioso y teológico, como la creencia del mercado total, la trans-ontología del mercado como única posibilidad de ser. Uno de los elementos que podría considerarse como propio de la concepción moderna del tiempo, es que este se desprendió del determinismo, y abrazó una idea cuantificable del tiempo: "el tiempo es oro", afirma el refrán popular que caracteriza dicha interpretación. Lo anterior supuso remplazar la idea del kairos, por la del chronos cuantitativo con su expresión empírica en el 'reloj': "El tiempo occidental se liberó cada vez más de los ciclos naturales y cósmicos (día y noche, fases lunares, estaciones del año), para convertirse en un simple marco de referencia cuantitativo de la experiencia humana" (Estermann, 2008, p. 125).

La manera de comprender el tiempo en relación a un determinado progreso histórico de la humanidad, tendrá su máxima expresión en el movimiento de la Ilustración que con su lectura historicista, considera que la historia del hombre se desarrolla en el tiempo, pasando de estadios menores de conciencia, del 'espíritu', a etapas, incluso de mejoramiento genético, dando paso a la superación de elementos precarios que van quedando relegados por el ascenso del 'espíritu'. Es claro que esta manera de comprender el tiempo, ha sido clave para la comprensión de las dinámicas económicas, políticas y sociales, propuestas por los 'padres' del neoliberalismo, como Hayek, Fukuyama o Smith, entre otros célebres representantes del movimiento (Hinkelammert, 1999). De allí que si bien es cierto, el proyecto de la Ilustración sacó de su campo de comprensión la religión, no así el optimismo progresista que se expresó en toda una suerte de utopías políticas.

Lo que es común a todos estos movimientos es la concepción del tiempo como un marco dentro del que el ser humano se perfeccione cada vez más hasta llegar a un estado supuestamente "perfecto" que se denomina de acuerdo a la ideología como "sociedad sin clases", "mercado libre", "espíritu absoluto", "superhombre" o "paraíso hedonista" (Estermann, 2008, p. 127). 
La manera como el neoliberalismo ha desarrollado dicha progresividad del tiempo, se deja ver también en su determinismo, al considerar inevitable e irreversible el 'desarrollo' del capital, por vía de la "libertad mercantil". En otras palabras, en el neoliberalismo absolutiza el mercado, este es necesario y 'sustancial', mientras que todo lo que no esté en la 'línea' del progreso, es visto como una accidentalidad, irracionalidad, y por lo tanto amenaza a lo único lógico y racional, a saber, el 'mercado total'. Justamente aquí radica uno de los matices no observados por la crítica posmoderna a los metarrelatos desde los que se funda la racionalidad occidental, a saber, que con el neoliberalismo no hay tal muerte de los 'grandes relatos', sino la absolutización de los metarrelatos, en un único y gran relato, el capitalismo mercantil.

Esta 'nueva' noción del tiempo, impuesta por vía del mercado total, se soporta en la idea de un tiempo lineal, progresivo y cuantificable, en el cual el devenir de todos los pueblos, tarde o temprano habrán de 'llegar'; de allí nace también la lógica desarrollista, para la cual los pueblos andinos están en 'vía de desarrollo':

El "desarrollismo" -siempre muy vigente en Occidente- parte de la presuposición de que las y los que están "atrás" tienen que recuperar el tiempo para nivelarse con los que están "adelante". Y esta idea presupone una concepción del tiempo que considera el progreso como un proceso histórico inevitable e irreversible (p. 126).

Esta visión del 'desarrollo', evidentemente vinculada con unas comprensiones particulares del tiempo, es uno de los elementos de la actual colonialidad que más se ha desplegado y se sigue desplegando sobre América Latina. De allí que pensar el tiempo desde la perspectiva andina, supone, por demás, deconstruir los paradigmas desarrollistas desplegados sobre las dinámicas sociales del Abya Yala. El desarrollo occidental, por vía de la industrialización, la tecnología y la globalización del mercado, adquiere otras tonalidades a la luz del tiempo andino, que se expresa de manera especial en la propuesta panandina del Suma Qamaña.

Si para la racionalidad moderna el despliegue del tiempo en el devenir social impulsa la historia hacia el progreso y el desarrollo, para la racionalidad andina, la relacionalidad 
cósmica del tiempo, su no linealidad, impulsa la historia hacia el Suma Qamaña, hacia la Jaka o vida, que no puede ser sin su polo complementario, Jiwa o muerte.

La complementariedad de los opuesto, Jaka y Jiwa, permite llegar a aquello que Torrez (1994), ha denominado ontológicamente "el lugar del ser", o Qama. Ello indica que para encontrar un equivalente homeomórfico al "desarrollo" occidental, la filosofía andina requiere ubicarlo en el espacio-tiempo concreto o pacha. Ha de recordarse al respecto que en aymara no se encuentran sustantivos abstractos, por lo que se da una 'lógica de lo concreto' que no permite un reduccionismo, sino un 'relacionismo'.

Medina (2006), comentando el abordaje 'complejo' que postula Torrez, para hacer referencia a lo que podría ser un equivalente homeomórfico de la noción occidental de 'desarrollo' -en tanto puesta en marcha de una determinada interpretación ontológica del tiempo-, se vale de tres términos que no pueden disociarse, sino que comparten una relación de correspondencia: Qama, Jaka, Jiwa, a los cuales Torrez (1994) añade el sufijo 'ña' que da lugar a la traducción de estos, como: Qamaña o 'lugar del existir', Jakaña o 'lugar de vivir' y Jawaña o 'lugar de morir'. Ahora bien, en coherencia con la relacionalidad andina, el Jakaña, es en sí mismo una totalidad, pero al mismo tiempo es parte del Jiwaña; y esto evidentemente es problemático para la lógica occidental que junto con Descartes, busca las “ideas claras", como cuando se dice que A es A y no B a la misma vez y en el mismo tiempo, pero no puede ser A y B, en el mismo sentido. Por otra parte, la Jakaña de la que se co-responde la Jiwaña, son parte de una realidad más grande, la Qamaña:

Dicho en otras palabras, cada uno de estos conceptos es una totalidad-parte, es decir, un holón (...) una entidad que es al mismo tiempo, una totalidad y una parte de otra totalidad (...) sorprendentemente los aymaras, como los sistémicos de la segunda mitad del siglo $\mathrm{xx}$, han resuelto de la misma manera el debate filosófico bimilenario entre atomistas y holistas sobre cuál sea la realidad última, si la totalidad o la parte (Medina, 2006, p. 33).

El Qamaña, como 'lugar del ser-estar', del existir, es la chakana relacional que permite la dialéctica complementaria y recíproca, entre Jaka y Jiwa. En este sentido, 
la 'existencia auténtica', ya no del Dasein heideggeriano, sino del runa/jaqi andino, no se soporta en asumir una existencia de cara a la muerte como condición última e ineludible -que en el caso del sujeto andino ello representó no la posibilidad de ser Dasein, sino la condición de damné-, sino de cara al mantenimiento del equilibrio cósmico, donde el ser-estar, el Qamaña, es la posibilidad misma de lo que se dice que es.

El runa/jaqi andino no teme a la muerte como lo supone la idea de 'existencia inauténtica' heideggeriana, por lo que no requiere 'asumir la existencia', su temporalidad, de cara a esta. Ello se debe a que la Jaka o vida, solo es comprensible en su polo complementario, Jiwa o muerte. La expresión aymara de Jiwa, está compuesta por un prefijo de conjunción, Ji, que tiene el sentido de 'junto, al lado' y el radical wa que connota 'tierra', fundamento, origen; en sí mismo el concepto tiene el sentido de 'estar juntos', 'volver a la tierra', 'estar junto al ser' (p. 31). En este mismo sentido señala Medina que:

(...) el hombre andino, en principio no teme a la muerte, pues no la percibe como un final, sino como una transición, como una sinapsis entre dos voltajes diferentes de una misma energía cósmica, Qamasa, de donde dimana "una nueva vida”. La serpiente se muerde la cola; esa conjunción es Jiwa (p. 32).

De allí que la interpretación de la muerte en el Qamaña, no es el fin de la temporalidad y temporaneidad del Dasein, ni la imposibilidad de experienciar el fenómeno del tiempo, sino movimiento, acción y apertura. Incluso para Torrez, Jiwa por su carácter de transición, de chakana suscita belleza, pues en este los contrarios se unen, siendo que la Jiwa es algo que sale de la Jaka es decir, que está contenido en esta. Nuevamente se constata una lógica de la complementariedad de opuestos que evidencia una 'ontología' sui generis.

Esta perspectiva de la Jiwa en el Qamaña andino, permite que la Jaka misma sea asumida de otra manera que en Occidente. Mientras el eludir a la muerte, lo nefasto en la perspectiva kuschiana, se convierte en el proyecto inauténtico del ser-ahí, y por ello el arrojo de la subjetividad moderna occidental a la técnica, la 
tecnología y la cibernética, como quien quiere proyectarse en el tiempo huyendo de lo ineludible y que cree concretizarlo en aquello que se ha denominado como 'desarrollo'; una nueva instancia teleológica donde el ser del sujeto colectivo tiene que llegar y para ello tiene que 'aprisionar el tiempo', 'comprar el tiempo'.

Otra característica del Qamaña como equivalente homeomórfico del 'desarrollo' de Occidente, es que este comprende el tiempo-espacio como algo vivo, es decir, compuesto y co-habitado por seres vivos en una densa relacionalidad y ello tiene serias implicaciones para la búsqueda del Suma Qamaña: “Así, para los aymara, el subsuelo, el suelo, el agua, el aire, las montañas no solo están vivos, sino que son, además los espacio-tiempos en que 'los seres espirituales están latentes'; los ecosistemas mismos: altiplano, valles (...) son organismos vivos” (p. 33). (Énfasis en negrilla nuestro).

Las implicaciones del Qamaña con relación a la con-vivencia de los ecosistemas, en tanto que estos son espacio-tiempo en densa relación con el runa/jaqi, imponen una dinámica del estar-en, del existir-con, que evidencian una concepción de la 'muerte/vida' como equilibrio, de allí que el papel del sujeto sea el de 'cuidador' del equilibrio, como en la Sorge heideggeriana.

La Administración de la biosfera, Torrez la entiende como "cuidado físico y espiritual" (...) usa dos conceptos para explicar más este sentido: Qaman: "cuidar como criar la vida", como Sorge y Pacha-qamana: el cargo del que cuida la tierra (...) la administración de la vida (porque de eso se trata en la concepción aymara de la gerencia de la biosfera) la administración está dirigida a un fin: "aprender a morir para vivir": vida/muerte no son dos magnitudes diferentes o separadas (...) coexisten (p. 38).

En claro contraste con la comprensión de la filosofía andina, los abordajes hegemónicos de la razón occidental tienen como punto de referencia con relación a los ecosistemas - a la diversidad de la vida-, su utilitariedad, 'coseidad', 'monetarización' y cuantificación. En última instancia, ello ejemplifica una racionalidad que además de justificar la actual y futura situación 'medio-ambiental', asume la muerte desde una perspectiva del 'suicidio' como manera de estar 'auténtica'. 
Mientras la lógica del desarrollo occidental desarticula los vínculos relacionales del ecosistema que harían posible evidenciar la irracionalidad de lo racionalizado en el sistema económico actual, el Qamaña propone la 'interconectividad' del todo ecosistémico, es decir, el 'desarrollo' andino es:

(...) Trama de vida cuya mutua interconectividad produce bienestar (...). El supuesto de la concepción occidental moderna es, justamente, la inversa. La noción de un universo orgánico, viviente y espiritual fue remplazada por la del mundo como máquina y esta se convirtió en la metáfora dominante de la era moderna (p. 34).

Solo en el marco de la interconectividad, de la relacionalidad, podrá darse el Qamaña, como lugar placentero de la existencia, pero también el Jakaña, como 'lugar placentero de la vivencia. Torrez (1994) establece una distinción entre Jakaña y Qamaña, en tanto el primero hace referencia al 'espacio interno' de sobrevivencia, al lugar de la reproducción; y el segundo al 'espacio externo, el del entorno, del medio ambiente, en definitiva, el lugar placentero de la existencia. En ese sentido nuevamente sorprende la noción del desarrollo en perspectiva andina, pues se sintetiza en la idea del "Bien-estar" "Buen-vivir": "Bien-estar" como una dualidad complementaria: Jakaña es "el bienestar del hogar en la casa” y Qamaña es "el bienestar de la comunidad en el ayllu" (p. 36). Llama la atención que en ninguno de los dos casos se hace referencia al individuo como sujeto del bienestar, sino al Jaqi, al hombre mujer, a la dualidad complementaria dentro de una 'red' más amplia. Justamente por ello en el Qamaña, en contraste con el 'desarrollo', no se propende por la homogeneidad -o por una diversidad centrada en la esteticidad del otro y en el consumo-, sino por la 'unidad de la diversidad'.

Es comprensible entonces cómo desde el Qamaña, no puede haber un 'desarrollo' que integre el 'bienestar' de todos los elementos de la relacionalidad cósmica. El Qamaña como el arte de la 'buena administración' de la relacionalidad cósmica, hace interactuar las diferentes partes de la realidad, de allí la imposibilidad de pensar una economía que se plantee de espaldas a las consecuencias medio-ambientales o que 
se sustente en la eliminación de una de las partes-totalidades que integran el cosmos. De allí que citando a Torrez, Medina (2006) afirme: "Hoy en día el desarrollo material nos empuja y obliga a competir, sacrificando parte del Qamaña, perdiendo algo de la complementariedad equilibrante" (p. 46).

\section{Sintesis de la propuesta y camino para una ontología relacional}

El abordaje de la pregunta por el tiempo en la tradición occidental en las últimas décadas ha estado debatiéndose entre dos posturas que parecerían estar en tensión y muchas veces en oposición epistémica. Por una parte, se ha dado un abordaje del tiempo desde una perspectiva filosófico-existencial y por otra, desde una perspectiva más abstracta y matemática -algunos creen que más objetiva-, donde se piensa el tiempo en relación a los fenómenos físicos y al movimiento mismo, y desde este horizonte se pretende responder, no solo por el origen del tiempo, sino por el Arjé, el principio de aquello que es. Justamente en esto último convergen los dos abordajes.

Antes del advenimiento de las teorías modernas de la física, la noción del tiempo en relación con el movimiento, había sido el resultado de los análisis de Aristóteles y posteriormente de Ptolomeo. El primero de estos postuló una noción del 'movimiento' y el 'tiempo' como 'eternos', resultado de su creencia en que el movimiento más perfecto era el circular; pero también, por medio de la observación alteró la cosmología de su tiempo al cuestionar la idea de la tierra como plana. Avanzando en la misma línea epistémica, Ptolomeo se aventuró, siglos después, a proponer un modelo cosmológico del universo que brindó un sistema preciso de predicción de los cuerpos celestes.

Ahora bien, uno de los primeros elementos en el campo de la ciencia que comenzó a quitar la hegemonía interpretativa del cosmos dada por Aristóteles y Ptolomeo, como también de la cosmología cristiana, soportada en los anteriores, fueron las investigaciones de Copérnico y sus revolucionarias ideas de un sol 
estacionario y el movimiento elíptico de los planetas en torno a este. Ideas que solo un siglo después serán tomadas en cuenta gracias a los abordajes de Kepler y Galileo Galilei. Sin embargo, será la publicación tardía de Philosophia Naturalis Principia Mathematica (1687), de Isaac Newton, la que permitirá elaborar unos principios lógico-matemáticos para analizar el movimiento y el tiempo, particularmente con la ley de la gravitación universal y explicar el movimiento elíptico de los planetas más pequeños en torno a los más grandes. Lo anterior puso fin a la idea de un universo con una 'frontera natural' y como algo estático. A esta misma conclusión llegaron los análisis de Hubble en 1929, cuando observó que las galaxias están tomando cada vez más distancia de la Tierra, lo que significa que en algún momento estuvieron densamente juntas, elemento que propició el Big Bang.

Estas observaciones cosmológicas tienen como consecuencia inmediata, la imposibilidad de la inmovilidad del universo, como lo había postulado Aristóteles, pero sobre todo impiden una explicación metafísica y teológica, tanto del Arjé, como del espacio-tiempo. La aparente inmovilidad del universo suponía la 'exterioridad' del tiempo, es decir, la idea de que el tiempo había sido puesto por un 'absoluto', pues 'nada se mueve, si no es movido por otro'; esto también queda fuera de la escena epistémica en un abordaje del tiempo-espacio que irrumpe con las ciencias físicas.

Por su parte, nuevas 'leyes' de la física, particularmente la síntesis newtoniana de la física de Galilei, tienen no solo implicaciones en las teorías del estagirita, sino también para la comprensión ontológica del tiempo que hasta el momento se soportaba en las ideas del movimiento propuestas por el sabio griego. El hecho radical de la imposibilidad de fijar un estándar absoluto de reposo, echó por el suelo la idea de que las cosas 'subyacían' en estado de reposo y con ello la dificultad de precisar acontecimientos exactos en el tiempo, ligados esencialmente con un espacio determinado y fijo. Sin embargo, será la teoría de la relatividad general de Einstein, la que genere mayor implicación en la concepción del tiempo, pues con esta se da la posibilidad de pensar el espacio y el tiempo, no como realidades distintas, sino combinadas, a manera de 'espacio-tiempo'. Noción que por demás 
coincide plenamente con la pacha andina, como tiempo-espacio, pero no con las implicaciones del tiempo como relativo al observador.

La teoría de la relatividad permitirá pensar el tiempo como relativo al movimiento constante del observador, es decir, el tiempo y el espacio son afectados por el observador o más exactamente implicaría que cada observador tiene su propia medida de tiempo. En definitiva, la idea revolucionaria que aportó esta teoría fue el hecho de pensar que el espacio y el tiempo no solo afectan, sino que son afectados por los acontecimientos en el universo. Ello es importante debido a que hasta el momento la creencia general consideraba que el tiempo y el espacio eran marcos fijos en los que subyacían los acontecimientos. De tal suerte que todo acontecimiento no era más que la metáfora del 'accidente' en relación con la 'sustancia' o espacio-tiempo, lo que tenía como consecuencia la creencia de que el espacio y el tiempo habían existido desde siempre.

Sin embargo, serán los estudios de Hawking y Penrose, sobre los teoremas de la singularidad, los que pretenderán lograr una teoría unificada en donde se probaría el 'principio' del tiempo mismo, según la cual, este habría tenido origen en un punto de densidad y curvatura infinita. La mecánica cuántica aporta al proyecto de unificación de las teorías un 'juego' matemático que consta de dos elementos centrales para medir el tiempo: la noción del espacio-tiempo euclidiano, y la idea de un tiempo imaginario. El primero hace referencia a que en el espacio-tiempo 'euclidiano' no existe la diferencia entre direcciones temporales y espaciales; el segundo es resultado de la 'suma de historias' que no es otra cosa sino la fórmula por medio de la cual las ondas de una partícula, que están en el campo de lo 'real', son sumadas a 'historias de la partícula' que no están en el tiempo 'real'. Es decir que el 'tiempo imaginario', dado solo por medio de la matemática, sería la única forma para conocer el tiempo 'real'. El teórico inglés reconoce que hay diferencias fundamentales entre lo que denomina el tiempo 'imaginario' y el 'tiempo' real. En el tiempo real, las personas tienen la capacidad de recordar el pasado y no el futuro, lo que se explica por el principio de entropía, del que el inglés construye su idea de "flecha del tiempo", por medio de la cual se da respuesta a la capacidad del ser humano para recordar el pasado y tener noción del futuro. 
Algo es evidente en los abordajes del tiempo en la física occidental, por una parte su capacidad de abstracción lógico-matemática para pensar el tiempo, y desde allí, la posibilidad de de-sustancializar el espacio-tiempo; pero por otra parte, queda claro que sus límites parecen ser no las fórmulas matemáticas del tiempo, sino la experiencia del tiempo en el sujeto, que aunque se pretende explicar desde el principio de entropía, siempre deja espacio para lo no medible, para lo no cuantificable.

Justamente las reflexiones heideggerianas del tiempo, logran captar las limitaciones de la razón para dar cuenta de la experiencia del Dasein como seren-el-tiempo, y del tiempo mismo como 'posibilidad de manifestación del ser'. Por dispares que puedan parecer el proyecto de la física y de la ontología heideggeriana, ambos proyectos persiguen la búsqueda del ser, solo que Heidegger parte del lugar al que la física llega por medio de la 'flecha del tiempo'; y es justamente la particularidad óntica del único 'ente' que pregunta por el ser. Es evidente que para Heidegger la comprensión del ser, tiene su punto de partida en la analítica del Dasein, y este tiene como característica fundante la temporalidad. Es decir, el tiempo permite la comprensión misma del Dasein. Sin embargo, la temporalidad es meramente una característica fundante del ser del Dasein, pero ello debe ascender a una etapa ontológica que se caracteriza justamente por pensar aquella temporalidad como problema en relación al ser, de allí la idea de temporaneidad. Esta requiere una reflexión ontológica de la temporalidad que constituye al Dasein. Por su parte la temporalidad es el mismo 'tiempo vulgar' por el que Heidegger inicia su búsqueda del ser.

Si bien Heidegger es consciente de la limitación del lenguaje para captar las dimensiones ontológicas del tiempo por medio del concepto, parte su investigación buscado desentrañar el sentido del tiempo en las propuestas 'conceptuales' de Aristóteles y san Agustín. Observa, al igual que Hawking, que la noción del tiempo para el estagirita estaba vinculada con la física y el movimiento, sin embargo, poco le interesa al alemán la precisión matemática de la física aristotélica, sino su vinculación del tiempo con el ser. De tal suerte que el tiempo aunque es interpretado en relación al movimiento, este no es propiamente el movimiento 'simple' de la física que supone el desplazamiento de un cuerpo por un determinado 
espacio, pues queda claro que aunque el tiempo no es el movimiento, sin este, no hay tiempo (es lo que el principio de entropía en la física quiso demostrar).

En la interpretación heideggeriana de Aristóteles, queda claro que para el alemán la manera como el estagirita comprende el tiempo, como algo numerado con relación al movimiento, no da luces para comprender el fenómeno mismo. Ello se debe a que el tiempo no es parte del movimiento, sino 'algo' en relación a este; elemento que el sabio griego no logra dimensionar y por ello cae en la tautología de que 'el tiempo es tiempo'. A esta misma manera de comprender el tiempo, el alemán dio el nombre de 'tiempo vulgar' o 'temporalidad', ya que en esta modalidad del tiempo, este es algo numerado con respecto al movimiento y ello solo se puede dar el horizonte de los límites del tiempo que son el 'antes' y el 'después'; como la "flecha del tiempo" de la que hablan los físicos.

En la comprensión del tiempo vulgar, el alemán se percata de que el movimiento requiere de un 'aquí' y 'allí, mediado por la retención de un determinado 'aquí, lo que no necesariamente es la inmovilidad y la permanencia, pero sí la condición de la captación del movimiento y por tanto del tiempo vulgar. Ello da paso para pensar el 'ahora' como elemento central de comprensión del tiempo, en tanto sucesión de 'ahoras'; por ello es explicable la noción de pasado, como 'ahora-ya-no' y futuro, como 'ahora-todavía-no'. Es decir, la 'flecha del tiempo' de la física, no es más que la expresión del 'ahora'. Estos 'ahora numerados', justamente son la constitución del tiempo vulgar. Lo particular de esta modalidad del 'ahora' radica en que no es un punto fijo, sino que siempre está cambiando, es un continuo que 'no se mueve, pero tampoco está quieto', caracterizado por la apertura a un 'ya-no' y a un 'todavía-no'.

Lo anterior no significa en manera alguna que el tiempo, desde esta perspectiva, sea la sumatoria de 'ahoras', sino que el ahora denota presencia y marca límites, sin que este sea limitado. Por demás, ello tiene como consecuencia que el tiempo tenga un caracter abarcativo, pues el movimiento mismo se da en el tiempo, es intratemporal; de allí que el filósofo concluya que el tiempo es más objetivo que cualquier objeto, y que una de las consecuencias del tiempo 'vulgar', será que este aparece como una característica del sujeto; en esto estarían incluidas las 
perspectivas tradicionales de la física. Ello es comprensible, pues el 'ahora' siempre es un 'ahora-para', es decir, es un 'ahora' en relación a otro ente, lo que tiene como consecuencia que el tiempo tenga un carácter de significatividad mundana, donde por ejemplo se puede dar la databilidad, que siempre tiene relación con otro 'algo' a partir de lo cual se determina el tiempo.

La determinación del tiempo en el 'ahora' deja entrever entonces una estructura 'temporal', según la cual el tiempo no solo tiene un carácter de significatividad, sino que también es distendido y extendido, en tanto que, tal como se revela en el 'ahora', siempre será un 'ahora-mientras', es decir, tiene también un carácter de transitividad. Todas estas son expresiones de la mundanidad del tiempo y permiten comprender las características ontológicas del Dasein, como ser-en-el-tiempo, a saber: que el Dasein siempre se encuentra como a la espera de algo, de un 'ahora-todavía-no', por lo que constantemente está anticipándose a su poder-ser más propio, como proyectado al futuro.

Por otra parte, en el 'retener' propio del 'ahora-ya-no', el Dasein es aquello mismo que se 'retiene' en lo que 'ya-ha-sido'; el Dasein permanece en el 'ahora-mismo'. Es por ello que el Dasein no puede desprenderse sin más del pasado, como tampoco puede hacerlo de la muerte, pues el 'haber-sido', el 'ahora-ya-no', junto con la distensión del 'ahora-todavía-no' y el 'ahora-mismo', constituyen la posibilidad misma de su existencia, en tanto estos 'temporalizan' la temporalidad, pues son las condiciones mismas de la temporalidad, y por tanto constituyen ontológicamente al Dasein. En este sentido el filósofo no solo realiza una interpretación existencial del tiempo aristotélico, sino que redimensiona el tiempo mismo, desde la idea de la temporalidad del tiempo.

El tiempo en su característica de temporalidad es el que permite que el 'ente' salga al encuentro del Dasein, es decir, la serie de ahoras, en cuanto presentificar, retener y anticipar ('ahora-ya-no', 'ahora', 'ahora-todavía-no'), radicalizan el carácter de la 'presencia', pues todas las características de la temporalidad se condensan en una 'ahora-presente'. Es por ello que el tiempo en esta perspectiva es 'aquello' por medio de lo cual el mismo Dasein es; por ello es un ser-en-el-tiempo, tanto como un ser-en-el-mundo, y estrictamente hablando es el único ser-temporal por naturaleza. 
El vínculo del tiempo con la ontología, se debe entonces al hecho de que todo lo que existe, existe siempre en el 'ahora', o mejor, en el 'ahora' subsiste todo aquello que es, por lo que el tiempo mismo es co-existente con el ser que hace 'presencia' en el 'ahora' de los 'entes', con los cuales el Dasein no solo puede conocer el 'mundo', sino principalmente comprenderse a sí mismo como ser-en-el-mundo y ello a su vez se constituye en una determinación fundamental del Dasein. El comprender-se se da entonces como la proyección del Dasein, como actitud ante la 'presencia' del 'ahora', cuya autenticidad radica en la posibiliadad del Dasein, no tanto de conocer los 'entes', sino de comprender su poder-ser más propio y más originario y esto solo es posible considerando las determinaciones temporales que le acaecen.

Es central entonces comprender que el ser mismo para la ontología heideggeriana, es 'presencia', lo que tiene como implicación, nada menos, que el ser es determinado por la 'presencia', en tanto una determinada forma del 'ahora'; por ello es que los 'entes' son donados, dados en el tiempo. Ello no supone necesariamente que el ser sea una 'cosa' con relación al tiempo, sino meramente que el ser solo puede develarse en el tiempo, pues el tiempo 'pasa', como en la serie de ahoras y aquello de que 'pasa' manifiesta el hecho de que el tiempo habla del ser; de aquello que permanece en el pasar, pero se manifiesta en la 'presencia' radical del ahora. Todo lo anterior tiene como consecuencia que del 'ser' y del 'tiempo' no se pueda predicar nada, pues estos no son 'cosas', sino la posibilidad del ser de las cosas. De allí que del tiempo solo se pueda conocer que es el 'donador' de las cosas y solo en ese sentido puedan tematizarse el ser y el tiempo.

Por lo anterior es que desde esta perspectiva el tiempo no está dado por o en relación al espacio, ni es consecuencia de este, pues el tiempo no es un lugar, como tampoco es una cosa, sino que es condición de lugar o posibilidad de 'lugar'; esto supera la noción del tiempo numerado y cuantificable con relación a un determinado movimiento (en tanto desplazamiento de un 'objeto' en el espacio). De allí que en aquella expresión de 'Se da el Ser', como 'presencia', el 'Se' se corresponda con el tiempo, sin el cual el ser no puede darse, es decir, donarse.

Esta característica de la 'presencia' del ser, es justamente lo que impulsa en la racionalidad andina, la ritualidad. Por medio del rito, la celebración y lo simbólico, lo 
que es, puede hacerse concreto, y por lo tanto, dado que el ser es 'presencia', el lugar del runa/jaqi es la escucha, la apertura y el mantenimiento del equilibrio cósmico.

La razón por la cual el capítulo segundo se ocupa de la noción del tiempo-espacio andino no obedece, como podría interpretarse erradamente, a una jerarquía de la razón occidental sobre una sabiduría milenaria como la andina; por el contrario, el abordaje de las perspectivas occidentales, evidencia elementos y límites que en la sabiduría andina popular son, no solo integrados, sino tensamente conciliados en su lógica relacional. Ello no supone una idealización del conocimiento y las culturas andinas, menos aún una esencialización indigenista o pachamamista, sino un esfuerzo de diálogo entre 'paradigmas' de conocimiento que siempre resultará tenso y en muchos casos, como diría Kusch, "hediondo". En esto último radica lo paradójico de realizar una 'ontología del tiempo andina', o una construcción 'ontológico-decolonial' del tiempo andino.

Si bien Heidegger se percata de la imposibilidad del concepto para hablar del ser, el abordaje del pensamiento andino lo constata en toda su dinámica simbólico-racional. El pensar andino no parte de la positividad sin más de los 'entes' (como de su utilidad) y de su conceptualización, sino de su negatividad y allí puntualiza y concretiza la existencia posible de las cosas; es decir que mientras un paradigma de pensamiento objetiviza y conceptualiza, el otro 'niega' debido a que comprende que el punto de partida no puede ser el concepto, sino existencia misma, el 'estar-ahí y por ello el concepto solo es una segunda parte de la realidad, pues esta antes que conceptual es simbólico-celebrativa.

Ello supone que el abordaje de lo 'real', de aquello que 'es', puede cargarse en dos polos, un polo positivo que nombra, apropia y que es considerado por la colonialidad del saber como el polo objetivo; y otro que por el contrario 'niega', soportado en la existencia misma, en el mero estar, en cuyo lugar ocupa un papel central la celebración, el rito y la fiesta, pero no como meras expresiones folclóricas para estetizar y despolitizar en el mercado de las experiencias culturales de una posmodernidad cada vez más útil al actual sistema capitalista; sino como profundas expresiones onto-filosóficas, olvidadas por la cultura hegemónica occidental, pero 
presentes y vivas en el devenir andino, y particularmente en las culturas quechumaras del Abya Yala.

Esto que Rodolfo Kusch denominó como 'lógica de la negación', permite evidenciar el papel fundamental de una filosofía subalternizada por no partir del concepto como representación ideal de la realidad, sino del símbolo, como condensación y presencia de lo real, pues para la razón occidental dicho abordaje es evidencia de un pensamiento mítico y preconceptual, por lo tanto subalterno. Justamente comprendiendo y valorando ese marco mínimo de referencia racional-relacional andino, es que la noción de tiempo-espacio puede ser abordada y mejor comprendida en su propio horizonte filosófico.

La forma particular en el que se da el pensar andino se constata de manera especial en el conocido término Pacha, el cual no solo connota lo que en castellano serían los términos: tierra, globo terráqueo, naturaleza, sino que además tiene un sentido de totalidad de lo real y de espacio-temporalidad; lo que hace que la idea de pacha tenga implicaciones filosófico-ontológicas aún no profundizadas lo suficiente por la filosofía latinoamericana. En la lengua aymara, por ejemplo, el término pacha como sufijo tiene un claro sentido de totalidad: taq pacha, 'absolutamente todo'; pero también como sufijo agregado a un nombre, denota 'mismidad'. Es en este sentido que el término pacha adquiere una connotación general y más filosófica de 'universo ordenado en categorías espacio-temporales', pero no referidas meramente a la materialidad de las 'cosas', como cuando se traduce pacha de manera simplificada como tierra y globo terráqueo, sino como concepto integrador de las múltiples realidades, las visibles-invisibles, lo alto-bajo, lo cercano-lejano, interior-exterior; de allí que ontológicamente se diga que en el pensar andino, la Pacha, es 'lo que es', es todo lo que existe, es la realidad.

Por lo anterior es que el filósofo argentino Rodolfo Kusch, prefiere pensar el término en un sentido más vital, como un 'aquí y ahora', como hábitad. Allí adquiere mayor sentido la comprensión de la pacha en diferentes facetas, una de las cuales llama especialmente la atención por representar no solo una determinada espacialidad, sino una condición espacio-temporal ontológica de la existencia: el kay pacha, 'este pacha' 'aquí pacha', un 'aquí y ahora'. Sin embargo, las diferentes 
facetas espacio-temporales (hanaq/alax pacha, kay/aka pacha y uray/manqha pacha) son reconciliadas-tensamente, en la idea de totalidad que contiene la pacha.

Estas mismas dimensiones de la pacha son recreadas en el dibujo del Altar de Coricancha realizado por Pachachuti. Allí las diferentes partes que integran la realidad son ubicadas de manera tal que se evidencia una correspondencia entre las esferas horizontales y verticales; tal en la relación horizontal complementaria de hombre/mujer, en el espacio del kay pacha, como en la de sol/luna del hanaq pacha hanaq pacha y la complementariedad entre lo de arriba y lo de abajo. El dibujo en su totalidad deja ver claramente la lógica andina -seguramente inconscienteen relación con el espacio-tiempo que se da en la Pacha. Ello es más significativo cuando dichas espacialidades o estratos de la pacha, son vistos como reflejo de una racionalidad sui generis, de la que el dibujo del yamqui, solo es una confirmación pictórica. La relacionalidad del espacio en el dibujo permite entrever ya algunos principios del pensar andino como lo es la relación de correspondencia entre arriba/abajo y la de complementariedad de los elementos en la derecha/izquierda (hombre/mujer, sol/luna), así, cada elemento está integrado en una red de complementariedad y correspondencia, en la que la chakana central es el punto más denso de convergencia de las diferentes polaridades. Ello también permitió comprender el valor del símbolo y del rito como formas de conciliar la relación entre el hanaq pacha y kay pacha, también como chakana, en tanto concilia las diferentes esferas de la realidad total, la Pacha.

El espacio-tiempo del kay pacha, del 'aquí-ahora', es a su vez una chakana, entre el mundo de los muertos o mundo de abajo y el mundo de arriba; por ello el indio andino es cuidador del equilibrio por medio de los rituales, las fiestas y toda una suerte de expresiones que representan una profunda manera de estar en el tiempo-espacio, en el kay pacha, pues en este espacio-tiempo se juega la 'suerte toda' del universo, de todo aquello que es. Cuando se observa la gráfica de Pachacuti del Altar Mayor de Coricancha, es evidente la manera como ubica en el campo del kay pacha los cuatro elementos -agua, fuego, aire y tierra-interrelacionados espacio-temporalmente, pero también en correspondencia con las dinámicas del hanaq pacha. No hay nada en el Altar de Coricancha que no tenga una relación 
complementaria y recíproca, en la espacialidad de la gráfica; ello muestra la profunda lógica relacional desde la que se piensa el tiempo andino; pues de la misma forma que los elementos en el altar se corresponden, los tiempos que los mismos representan tienen su reciprocidad simbólica en el tiempo del kay pacha. El tiempo de las dinámicas del 'mundo de arriba', de Viracocha, tiene una relación recíproca en las dinámicas y tiempos del kay pacha (las cosechas, las épocas de lluvia, de sequía), por ello la festividad es una manera de hacer converger los espacio-tiempos en la densidad del símbolo ritual.

Las dinámicas del espacio-tiempo andino, es decir, las implicaciones filosóficas de la Pacha, no solo pueden ser graficadas en la disposición relacional de los elementos en el Altar de Coricancha, sino también en la rica y variada narrativa mítica de los Andes.

La narrativa andina está impregnada de dualidades complementarias y de relaciones de correspondencia, reconciliadas siempre en la idea de chakana. Ello incluso marca las dinámicas de organización espacial, política y cultural del pueblo aimara alrededor del lago Titicaca, pues este es considerado la paqarina o fuente de donde surgió la vida, y también se evidencia en las pampas o las plazas y la función que aún tienen como lugar de tenso encuentro entre las poblaciones de las tierras altas, Urqu, y tierras bajas, o Uma. Todo lo anterior apunta a evidenciar una racionalidad que pone su acento en el papel fundamental de la relación que se da en la chakana, en el taypi, como punto de encuentro, pero no a manera de síntesis de las polaridades, sino de la tensa pervivencia de las mismas para posibilitar aquello que estrictamente es, y que se manifiesta o devela no por medio del 'concepto', sino de la relacionalidad del todo, presente a través del espacio-tiempo chakánico del ritual. De allí que el papel del taypi, la chakana y el kay pacha tenga un fuerte sentido ontológico, pues representan el equilibrio de los opuestos que en sus polaridades no tendrían propiamente existencia.

Este sistema espacio-temporal del Altar de Coricancha, permite también explicar mucho de la noción temporal en sí misma para la filosofía andina. El tiempo, al igual que el espacio en la gráfica es un nodo-relación en el que convergen junto con el espacio elementos contradictorios y opuestos. De allí que el tiempo andino 
no es algo que se pueda numerar, no es un quantum que pueda expresarse matemáticamente y menos aún algo que el sujeto pueda 'tener'. Es un 'ahorita' que no permite medición, es un ir y venir constante que está co-presente con el espacio, es claramente otra de las manifestaciones de la pacha.

Esto significa que el tiempo tiene características más cualitativas que cuantitativas, pues es el que demarca cuándo determinados espacios son propicios para este o aquel acto; por ello el tiempo también es 'ritmo de vida', 'momento adecuado para'. Ello supone la negación de un tiempo progresivo que va dejando atrás al pasado, pues por demás el 'pasado' siempre es 'actual' en el kay pacha, por ello el runa/jaqi andino camina hacia el pasado, y es la chakana entre pasado y futuro; en esto justamente converge la perspectiva andina con el 'ahora' heideggeriano, con su característica de retener y proyectar.

Por otra parte, la posibilidad de pensar el tiempo andino en un horizonte ontológico, adquiere sentido únicamente cuando se comprende que aquello 'ontológico' no se corresponde a un marco de reflexión y de razonar puramente griego y occidental, como ciertamente lo creyó Heidegger. Es decir, cuando el horizonte de comprensión de las 'cosas' y del 'mundo' andino, emerge con voz propia, pero ya no como un saber subalterno y mitológico frente a un tal saber positivo, racional y lógico que se erige como paradigma único de ser. De allí incluso lo paradójico del pensar andino, cuando por el contrario del occidental tiende a esquivar el es de las cosas y se soporta en un estar, que siempre está ligado a las circunstancias y por lo tanto le preocupa menos la connotación del mundo y de los 'objetos'. Así, aquellas 'cosas' que parecen evidentes y objetivas a la razón occidental, se sumergen en la lógica andina en medio de las circunstancias; estas últimas parecen no tener el carácter de 'accidente' como en la ontología clásica, sino por el contrario parecen ser lo 'sustancial' y permanente.

Es obvio entonces que no se trata tanto de una imposibilidad de pensar el tiempo-espacio andino ontológicamente, sino que el marco de aquello que es para el pensar andino parece funcionar con una lógica propia y que ciertamente parece captar mucho más el sentido denso de aquello que emerge como lo que 'es'. Ese sentido 'hondo' del que se habla, se evidencia en la posibilidad de una racionalidad que comprende que lo que es, siempre está sumergido y sujeto a la circunstancia, 
a la densidad espacio-temporal del 'ahora' y en esto nuevamente el pensamiento andino encuentra un posible equivalente homeomórfico en el pensamiento de Heidegger, pues para este hay una relación entre el ser y el tiempo que se concretiza en el estar, el que a su vez es la temporalidad de aquello que es. Por ello se dice que en el estar se circunstancializa el ser.

El estar privilegiado por la racionalidad andina es aquello de lo que huye la razón occidental, pues su noción del ser, tanto como la del deber-ser genera un proyectarse en el mundo a través de la creación de objetos, de nominar el mundo e incluso el ser. Este carácter del estar, es justamente una consecuencia de la interpretación espacio-temporal, pues no se centra en lo permanente, sino en lo transitorio, pues estar, siempre toma distancia del ser, o mejor, el estar es la forma inconstante del ser andino; es por ello la autenticidad de la existencia del runa/ jaqi, ya no es tanto liberarse del 'uno', del das Man heideggeriano, sino buscar el equilibrio cósmico que permite que emerja aquello que es.

Sin embargo, el proyecto ontológico del ser colonizador y apropiador de la razón occidental ha subalternizado el estar y ha negado la condición óntica de aquello que no es según sus parámetros racionales. De allí que el proyecto del estar andino es un proyecto ontológico resistente (algunos dirían que es resiste a lo ontológico) y ejemplo claro de un verdadero ejercicio decolonial, en tanto se para ante la hegemonía de un ser inmóvil y en reposo y propone la inquietud del puro vivir, del mero estar como la condición prima del ser. Lo anterior es comprensible cuando se toma distancia crítica de la autenticidad del Dasein heideggeriano y su particular manera de asumir su destino, su proyección al futuro, su temporalidad, ya no tanto encubriendo el ser por medio de la técnica, sino por la asunción de la muerte como condición ineludible; sin embargo, dado que la racionalidad andina no parte de un sujeto que se emancipa de las determinaciones del das Man, sino que vive con el asedio constante de la muerte en los marcos de ese das Man, la muerte ya no representa su posibilidad última de ser, sino que el asedio de la misma en constante tensión con la vida, permite la emergencia de un damné, un sujeto al que a pesar de que se le ha negado su ser, pues se le ha ubicado como un ser-para-otros, emerge como cuidador del 
equilibrio cósmico, como vigilante de la vida/muerte, como realidad densamente integrada en el 'mero estar'.

Las consecuencias de una ontología que se soporta no en la permanencia de lo nombrable, sino en la circunstancialidad del estar, hace que las 'cosas', los 'objetos' del mundo, sean tomados no en su positividad connotativa, sino en su ámbito de negación. Esta negación es la misma que la razón occidental pretende tapar por medio del quehacer, como manifestación de una actitud que se proyecta hacia el futuro por medio de la creación de objetos y la capacidad de dar nombre a las cosas. Este quehacer occidental es justamente una forma de asumir el estar, o mejor, de huir del mismo, de entrar en el campo de lo seguro, del objeto, de lo permanente, de allí también que esta actitud busca alcanzar el ser, al cual el sujeto siempre tiende, solo que lo hace por medio de la técnica y del dar nombre, lo que le permite afirmar 'esto es' o un 'yo soy'. En contraste, el estar andino comprende que el ser es circunstancializado, absolutizado, no en lo nominable, ni en la creación de objetos, sino en el ritual-celebración, en la que se condensa la realidad-toda; por ello no está la tendencia a afirmar la 'cosa', en el 'yo soy', sino a negarla y circunscribirla a la circunstancia en el 'por ahora, estoy siendo X o Y'. Como se puede observar, en esta última el ser queda 'preso' de la circunstancia.

La manera particular en la que la circunstancia asume la eseidad de las cosas, se debe entre otros elementos a la disposición racional andina de mantener activos los 'operadores seminales' que no son otra cosa, sino la posibilidad de mantener en primer lugar el vínculo del sujeto con aquello que conoce y no la distancia cognoscitiva del nombrar y el conocer (distanciamiento epistémico). En otras palabras, la manera de pensar que activa los 'operadores seminales' permite una captación profunda de aquello que es, pues al soportarse en el 'puro-vivir', en el 'mero-estar', las cosas no son simples entes, sino que entran en un lugar emocional desde el cual se puede captar la realidad en su totalidad, y no solo en una de sus dimensiones, como es la nominalidad y objetivación de la misma; es por ello que la realidad-toda adquiere un valor simbólico pues descubre aquello que está detrás del dato sensible e integra este, por medio de la 'negación' del mismo, en un horizonte mucho más complejo en el que el mismo sujeto toma conciencia de 
sí mismo, tanto como de las cosas. De allí que este operador seminal en realidad sea algo previo al conocimiento y a la comprensión, sea un a priori de la ontología andina, pues este se soporta en la existencia misma que da lugar como segundo momento al conocer y comprender.

Es por ello que todo lo conocido y lo que se denomina como el es de las 'cosas', termina en el estar andino incorporándose a aquello conocido en el horizonte vivencial del estar, de tal suerte que lo central no es el conocimiento, el dato, ni la conciencia del ser de las 'cosas'; ni del ser-en-cuanto-tal, sino el lugar de la 'cosa' (que no es cosa) en el horizonte de lo ya-dado, de la existencia misma; allí radica el hecho de que el pensar andino busque una 'totalidad del pensar' que ha sido ahogada por la razón occidental por medio del 'análisis' y la nominación de las 'cosas', que no es más sino la pretensión de disgregar el pensar por medio del silenciamiento del 'operador seminal'. Esta última, la razón occidental, parte de la inquietud con respecto a la ciencia, mientras la andina está preocupada por el hecho puro de vivir que es el fundamento del conocer mismo.

Por lo anterior es comprensible que el pensar andino al fundamentarse en el estar, no se preocupe tanto por la conceptualización y la abstracción de lo real, pues estos solo son parte de un vector del pensar que asume el es de las cosas, fuera de su posibilidad espacio-temporal, es decir, fuera de la manifestación del 'ahora', como presencia del ser, que subyace en el estar, en el puro-vivir. Dado que el ser no puede ser representado en el concepto, y menos aún en lo 'ente', hace presencia en forma densa por medio del símbolo en el que el mismo runa/jaqik está implicado. De tal suerte que lo 'real' es visto en el horizonte del símbolo, en sus múltiples relaciones e interconexiones que están implicadas siempre con el estar y que se evocan en la ritualidad comunal; de allí que se dé un saber emocional, pues el sujeto se integra e involucra a la pacha en el aka pacha o 'ahora-aquí, lo que hace de este un verdadero Hören des Sein, un 'oidor del ser'. Es por ello que la 'realidad' vista desde este horizonte, no está presente como una materia cruda que hay que descifrar con la cognición, sino está presente como símbolo.

El símbolo más que el concepto permite captar la densidad de la realidad, pues integra todo lo positivo y objetivo de la misma, pero inmersa en la negación del 
operador seminal, es decir, implica al runa como sujeto-sujetado a la realidad que se presenta en el símbolo. De allí que el principio de lo real, de lo 'ente', de aquello que es, sea la relación misma que se manifiesta en el tiempo-espacio ritual del símbolo. Mientras para la razón occidental la relación es un accidente de sustancia, para el pensar andino la relación es la 'sustancia misma', pues nada puede ser fuera de los múltiples vínculos y relaciones que le componen. El ser andino es la relación y por eso pacha es lo que es, pues ella es relación cósmica que integra las múltiples dimensiones de lo real, las cuales no son meramente conceptuales y cognoscitivas, sino también emocionales, seminales y fagocitarias.

De allí que la relación como nodo donde se da lo real, aquello que es, sea tomada como elemento trans-ontológico, pues al es, siempre subyace una relación y esta no es de carácter accidental, sino trascendente y esencial. Ello supone la imposibilidad de un 'ente' tal que no se dé en el marco de las múltiples relaciones, pues lo que da 'concreción' al ente, es justamente la interrelación. Por su parte esa 'interrrelación' como concreción de lo que es, solo puede darse en el marco de una dinámica del tiempo que circunstancializa, temporaliza aquel nodo-relación, es decir, el estar. Justamente por ello la relacionalidad andina presenta una trans-ontología que no inmoviliza el ser, sino que por el contrario el mismo deviene como energía dinamizadora.

Ahora bien, la relacionalidad andina al ser vista como trascendental, trans-ontológica, supone la superación de la lógica causa-efecto desde la que la razón occidental ha indagado su ontología. Si la relación es en sí misma la concretitud de los 'entes', de aquello que es, esta relación tiene como característica fundamental la bidireccionalidad, es decir, la correspondencia entre lo relacionado, lo que supone la superación de la jerarquía establecida entre causa-efecto, pues siempre en esta subyace una 'causa activa' a la que se debe la 'otra'. Esta relación de complementariedad y de bidireccionalidad no jerárquica es aplicada a todos los ámbitos de la vida, pues incluso Dios no puede ser pensado fuera de una relación-correspondencia con el runa/jaqi.

De tal modo, si la ontología andina pone la relación como 'nodo óntico', ello supone que los entes fuera del marco relacional de concretitud son incompletos, tienen lo que hemos denominado una 'deficiencia óntica', en tanto que su posibilidad de ser 
deviene en la relación misma. De tal modo que de la misma manera que el electrón requiere de la relación complementaria entre partícula y onda, el es andino requiere la misma relacionalidad complementaria pero en el marco de la realidad-toda. Así las cosas, la ontología de la relación andina, pone el fin de la lógica del 'objeto-sujeto' superando el campo de las críticas parciales al interior de la misma diástasis logocéntrica.

El puente o chakana en la que se relacionan las diferentes partes de la realidad, el aka pacha, impone una dinámica en la que el tiempo sale al encuentro de la develación del ser, de lo que es, pero soportado en la preeminencia del estar, donde el tiempo mismo está circunstancializado y se extiende en el nodo relacional de la pacha. Ello supone una determinada forma de vivir-el-tiempo, una manera, si no 'auténtica', sí profunda, en tanto correspondencia con lo que es. Si esto que es, es la relación; y esta relación no es de carácter causal y accidental, la manera profunda del pensar y del vivir, radicará en el mantenimiento del equilibrio cósmico, en tanto realidad-toda. Por ello, el tiempo andino no puede pensarse al margen del espacio andino, pues en efecto lo que se dice que es, lo es en relación situacional, circunstancial, espacio-temporal, lo que no es otra cosa sino una disposición con respecto al estar, como condición anterior al ser.

En este contexto es comprensible que mientras la proyección del sujeto occidental en el mundo se ha desplegado y reflejado en la negación de lo 'otro' como criterio de racionalidad y en la disposición de lo objetivado para prologar-se, proyectar-se en el tiempo; la propuesta andina postula el cuidado como vínculo con la pacha: el cuidado del ser, o mejor de estar en el aka pacha, por medio del mantenimiento del equilibrio y de la relación en todas las esferas de la vida. Lo anterior supone toda una estética, ética y política de la vida que dilata los márgenes de un tiempo y una racionalidad proyectada al futuro, y que encuentra su expresión económica en las lógicas del desarrollismo occidental, para el cual mientras siga una resistencia del pensar espacio-temporal como el andino, no solo estaremos en condiciones de subalternidad económica y política, sino que además se justificará allí, la imposibilidad de un estar-siendo, fuera de los márgenes del 'verdadero ser', para el cual todas las otras expresiones del ser, son meras accidentalidades, como los damné de Fanon. 

Referencias 

Academia Mayor de la Lengua Quechua. (2005). Diccionario Quechua-Español; Yachay Sapa, Wiraqucha Dun Qvixote Manchamantan. Cusco, Perú: Gobierno regional del Cusco.

Alberdi, J. B. (1842). Ideas para presidir la confección del curso de filosofía contemporánea. Leído en el Colegio de Humanidades de Montevideo. Recuperado de: http://www. biblioteca.org.ar/libros/869.pdf

Astrada, C. (1948). El mito gaucho. Martín Fierro y el hombre argentino. Buenos Aires, Argentina: Ediciones Cruz del Sur.

Askin, I. F. (1968). El problema del tiempo: su interpretación filosófica. Montevideo, Uruguay: Pueblos Unidos.

Barnes, M. (1992). Representations of the Cosmos: A comparison of the church of San Cristobal de Pampachiri whit the Coricancha drawing of Santa Cruz Pachacuti Yamqui Salcamaygua. Chicago, IL: Cornell University.

Barnes, J. (1992). Los presocráticos. Madrid, España: Cátedra.

Baumann, M, P. (ed.). (1996). Andean music, symbolic dualism and cosmology. En Cosmología y música en los Andes, Berlín, Alemania: Vervuert Iberoamericana.

Beltrán, P. (2003). Las nociones de tiempo y espacio en el calendario ritual de Cariquima. En Liminar, Estudios Sociales y Humanísticos, Vol. 1, № 2. Universidad de Ciencias y Artes de Chiapas, México. 
Bilbao, F. (1864). El Evangelio Americano. Buenos Aires, Argentina: Imp. de la Soc. Tip. Bonaerense.

Bilbao, F. (2008). El Evangelio Americano. La Habana, Cuba: Fondo Editorial Casa de las Américas.

Blanco Galdós, O. (1988). Tecnología andina. Un caso: Fundamentos científicos de la tecnología agrícola. Maximo Vega Centeno y otros, Tecnología y desarrollo en el Perú, Lima, Comisión de Coordinación de Tecnología Andina.

Brito, F. (1953). Obras de Farias Brito. Rio de Janeiro, Brasil: Ministerio da Educação e Cultura e Instituto Nacional do Livro.

Bruh, L. (2003). El alma primitiva. Barcelona, España: Ediciones Península.

Caso, A. (1972). Obras completas, vol. 7. México D. F., México: UNAM.

Castro-Gómez, S. (2011). Crítica a la razón latinoamericana. Bogotá D. C., Colombia: Universidad Javeriana.

Castro-Gómez, S., \& Grosfoguel, R. (2007). El Giro decolonial; reflexiones para una diversidad epistémica más allá del capitalismo global. Bogotá D. C., Colombia: Siglo del Hombre Editores.

Cepeda, J. (2008). Del problema del ser al ser como problema en América Latina. En El ser en América Latina. Bogotá D. C., Colombia. Recuperado de: www. Lolatinoamericanodelser.es.tl

Cepeda, J. (2010). Tras la comprensión del problema del ser. Avances de Investigación. Bogotá D. C., Colombia: grupo de investigación Tlamatinime sobre Ontología Latinoamericana, Universidad Santo Tomás.

Cepeda, J. (2013). Ontología indígena. En Aproximaciones ontológicas desde lo latinoamericano. Rosario, Argentina: Ross.

Cobo, B. (1964). Historia del Nuevo Mundo. Madrid, España: Atlas.

Conrad-Martius, H. (1958). El tiempo. Madrid, España: Revista de Occidente.

Cornejo, A. (1995). El principio de complementariedad en el pensamiento andino. Universidad y pueblo Vol. 5. 
De la Torre, A. (1985). Los dos lados del mundo y del tiempo: representaciones de la naturaleza en la Cajamarca indígena. Lima, Perú: CIED.

Díaz, J. (2005). El incaísmo como primera ficción orientadora en la formación de la nación criolla en las Provincias Unidas del Río de la Plata. California State University, East Bay. Recuperado de: https://acontracorriente.chass.ncsu.edu/index.php/acontracorriente/ article/view/128/254

Díaz, V. (1991). Filosofía en el Antiguo Perú. Lima, Perú: Nosotros.

Duvilios, P., \& Itier, C. (1993). Joan de Santa Cruz Pachacuti Yamqui Salcamaugua. Relación de Antiguedades deste reymo del Piru; estudio etnohistórico y lingüístico. Cusco, Perú: Institut Francais D'Études Andines; Centro de Estudios Regionales Andinos "Bartolomé de las Casas".

Estermann, J. (2006). Filosofía andina; sabiduría para un mundo nuevo. La Paz, Bolivia: ISEAT.

Estermann, J. (2008). Si el norte fuera el sur. Chakanas culturales. La Paz, Bolivia: ISEAT.

Estermann, J. Coord. (2009). Teología andina; l tejido diverso de la fe indígena. Tomo I. La Paz, Bolivia: ISEAT.

Estermann, J. (2009). Individualität und Kontingenz: Studie zur Individualitätsproblematik bei Gottfried Wihelm Leibniz. Berna, Alemania: Berna-Francfort/M.

Fanon, F. (1963). Los condenados de la tierra. México D. F., México: Fondo de Cultura Económica.

Fornet, R. (1994). Filosofía intercultural. México D. F., México: Fondo de Cultura Económica.

Gómez, A. (1945). La filosofía en Brasil. México D. F., México: Imprenta Universitaria.

González-Mestres, L. (2011). Pre-Big Bang, vacuum and noncyclic cosmologies, 2011 Europhysics Conference on High Energy Physics, Grenoble, July 2011, PoS EPSHEP2011(2011) 479, and references therein.

González-Mestres, L. (2014). Pre-Big Bang, space-time structure, asymptotic Universe. Spinorial space-time and a new approach to Friedmann-like equations. EDP Sciences. Recuperado de: http://www.epj-conferences.org/articles/epjconf/pdf/2014/08/epjconf_ icnfp2013_00063.pdf 
Guamán, P. (1615/1616). El primer nveva coronica y bven gobierno. (København, Det Kongelige Bibliotek, GKS $22324^{\circ}$ ). Copenhauge, Dinamarca: Biblioteca Real de Dinamarca. Recuperado de: http://www.kb.dk/permalink/2006/poma/info/es/ frontpage.htm/.

Guamán, P. (1956). La primera nueva crónica y buen gobierno. Lima, Perú: Editorial Cultura.

Guamán, P. (1980). El primer nueva corónica y buen gobierno. México D. F., México: Siglo xxi Editores.

Hawking, S. (1988a). A Brief History of Time. Toronto, Canadá: Bantam Books.

Hawking, S. (1988b). Historia del tiempo: del Big Bang a los agujeros negros. Traducido del inglés por Miguel Ortuño. Bogotá D. C., Colombia: Círculo de Lectores.

Hegel, G. (1970). Vorlesungen über die Philosophie der Geschichte. En Werke in zwanzig Bänden. Tomo 12. Frankfurt, Alemania: Frankfurt/M.

Hegel, G. (1986). Lecciones sobre filosofía de la historia universal. Madrid, España: Alianza.

Heidegger, M. (1975). Die Grunprobleme der Phänomenologie. Frankfut, Alemania: Frankfut am Main.

Heidegger, M. (1994). Conferencias y artículos. Traducción E. Baruj, Barcelona, España: Serbal.

Heidegger, M. (2000). Los problemas fundamentales de la fenomenología. Madrid, España: Trota.

Heidegger, M. (2004). Der Begriff der Zeit. Frankfurt, Alemania: Vittorio Klostermann.

Heidegger, M. (2005). La idea de la filosofía y el problema de la concepción del mundo. Madrid, España: Herder.

Heidegger, M. (2006). Ser y tiempo. Traducción Jorge Eduardo Rivera, Santiago de Chile, Chile: Trota.

Heidegger, M. (2006). ¿Qué es la metafísica? Bogotá D. C., Colombia: El Buho.

Heidegger, M. (2007). Zur sache des Denkens. Frankfurt, Alemania: Frankfurt am Main.

Heidegger, M. (2008). El concepto del tiempo: Tratado de 1924. Madrid, España: Herder.

Heidegger, M. (2009). El tiempo y el ser. Madrid, España: Tecnos. 
Herrera, D. (2003). Fenomenología y hermenéutica. (n.d.). Bogotá D. C., Colombia: Universidad Pedagógica. Recuperado de: http://www.pedagogica.edu.co/storage/ folios/articulos/folios17_04arti.pdf

Hinkelammert, F. (1984/1990). Crítica a la razón utópica. San José, Costa Rica: DEI.

Hinkelammert, F. (1997). El huracán de la globalización. San José, Costa Rica: DEI.

ISEAT. (2005). Lo "andino", una realidad que interpela. En Fe y Pueblo. Segunda época. $N^{\circ}$ 6. La Paz, Bolivia.

Kusch, R. (1999). América Profunda. Bueno Aires, Argentina: Biblos.

Kusch, R. (2000). El viaje. En Indios, porteños y dioses (1966). Obras completas, tomo I. Rosario, Argentina: Ross.

Kusch, R. (2003). El mero estar de la cultura quichua. En Obras completas. Rosario, Argentina: Ross.

Kusch, R. (2009). Obras Completas, tomo II. Rosario, Argentina: Ross.

Lander, E. (Ed.). (2000). La colonialidad del saber: eurocentrismo en las ciencias sociales. Perspectivas latinoamericanas. Buenos Aires, Argentina: Clacso.

Layme. (1996). La concepción del tiempo y la música en el mundo aymara. En Max Peter Baumann (Ed.), Cosmología y música en los Andes. Berlín: Vervuert Iberoamericana.

León-Portilla, M. (1956). La filosofía náhuatl: estudiada en sus fuentes. México D. F., México: Instituto Indigenista Latinoamericano.

Levi-Strauss, C. (1964). El pensamiento salvaje. México D. F., México: Fondo de Cultura Económica.

Louis, J. (1979). Lógica del tiempo. Madrid, España: Paraninfo.

Lovejoy, A. (1983). La gran cadena del ser. Barcelona, España: Incaria.

Maldonado-Torres, N. (2007). Sobre la colonialidad del ser: contribuciones al desarrollo del concepto. En Castro, S., \& Grosfoguel, R., (eds.). El giro decolonial. Bogotá D. C., Colombia: Siglo del Hombre Editores.

Mariátegui, J. (1968). Siete ensayos de interpretación de la realidad peruana. Lima, Perú: Biblioteca Amauta. 
Mariátegui, J. (1974). Temas de nuestra América. Lima, Perú: IEP.

Másmela, C. (2000). Martin Heidegger: El tiempo del ser. Madrid, España: Trota.

Manrique, F. (1988). Pachasofía y Runasofía. En Dos siglos de ensayistas pequeños. Lima, Perú: Universo.

Medina, J. (2006). Suma Qamaña; por una convivialidad posindustrial. La Paz, Bolivia: Garza Azul.

Mejía, M. (1994). Concepto de naturaleza en el pensamiento andino: una contribución a la filosofía universal: v Congreso Nacional de Filosofía. 1-4 agosto. Lima, Perú.

Mejía, M. (1999). Teqse: La cosmovisión andina y las categorías quechuas como fundamentos para una filosofía peruana y de América andina. Lima, Perú: Universidad Ricardo Palma.

Mejía, M. (2004). Teqse. La Cosmovisión andina y las categorías quechuas como fundamentos para una filosofía peruana y de América Latina. Lima, Perú: Universidad Ricardo Palma.

Mejía, M. (2005). Hacia una filosofía andina; doce ensayos sobre el componente andino de nuestro pensamiento. Primera edición computarizada: Lima, Perú. Recuperado de: www.filosofiaandina.com.

Mignolo, W. (1995). Decires fuera de lugar: sujetos dicidentes, roles sociales y formas de inscripción. Revista de crítica literaria latinoamericana. Año xxI, N 41. Medford, MA: Tufts University.

Montes, R., F. (1999). La máscara de piedra; simbolismos y personalidad aymaras en la historia. La Paz, Bolivia: Armonía.

Moreno, A. (2012). Los conceptos griegos de ser y tiempo. Aproximación al pensar ontológico de Heidegger. Bogotá D. C., Colombia: Universidad Santo Tomás.

Pacheco, J. (1994). Filosofía inka y su proyección al futuro. Cusco, Perú: San Antonio Abad.

Pardo, A. (2011). La ontología y la metafísica. En Dussel, E., Mendieta, M., Bohórquez, C. (Edits.). El pensamiento filosófico latinoamericano, del Caribe y "latino" (1300-2000). México D. F., México: Siglo xxi Editores.

Pucelle, J. (1976). El tiempo. Buenos Aires, Argentina: El Ateneo. 
Quijano, A. (1997). Colonialidad del poder, cultura y conocimiento en América Latina. Anuario Mariateguiano Vol. IX, № 9, Lima, Perú.

Radford, R. (1993). Gaia y Dios: una teología ecofeminista para la recuperación de la tierra. México D. F., México: DEMAC.

Radin, P. (1968). El hombre primitivo como filósofo. Buenos Aires, Argentina: Eudeba.

Rivara, M. (1992). El pensamiento incaico. En Robles Laureano (ed.). Filosofía Iberoamericana en la época del encuentro. Madrid, España: Trota.

Rivara, M. (1994). Wiracocha (Dios), Pacha (mundo), Runa (hombre) en la cultura prehispánica. En Filosofía, humanismo y realidad. Actas del iv Congreso Nacional de Filosofía. Arequipa, Perú: Universidad Nacional de San Agustín.

Salazar-Bondy, A. (1978). Sentido y problema del pensamiento filosófico hispanoamericano. Cuadernos de Cultura Latinoamericana 12. UNAM, México.

Salazar-Bondy, A. (1988). ¿Existe una filosofía de nuestra América? México D. F., México: Siglo xxi Editores.

Sobrevilla, D. (1986). Repensando la tradición occidental; filosofía, historia y arte en el pensamiento alemán, exposición y crítica. Lima, Perú: Editorial La Victoria, Amarú Ediciones.

Sobrevilla, D. (1992). ¿Pensamiento filosófico o pensamiento mítico precolombino? Cusco, Perú: Bartolomé de las Casas.

Tsit, W. (1965). Filosofía del Oriente. México D. F., México: Fondo de Cultura Económica.

Torres, D. (1967). El arte de la lengua aymara. Lima, Perú: Lyrsa.

Torrez, M., \& Yampara, S. (1994). La pacha y la pachamama en la producción. Paper, Cada, La Paz, Bolivia.

Urbano, E. (1991). Hacia una mitología andina. Allpanchis 9. 3-11. París, Francia.

Urbano, O. (1974). Representación andina del tiempo y del espacio en la fiesta. Allpanchis 7, La fiesta en los Andes. Cusco, Perú: Instituto de la Pastoral Andina.

Vasconcelos, J. (1929).Tratado de metafísica. México D. F., México: México Joven. 
Vasconcelos, J. (1990). La raza cósmica. Misión de la raza iberoamericana. México D. F., México: Espasa-Calpe.

Vega, J. (1974). Ensayo de una explicación metafísica del tiempo. Cuenca, Ecuador: Editorial Cuenca.

Waldemar, E. (1987). Los incas: economía, sociedad, y Estado en la era del Tahuantinsuyu. Lima, Perú: Amarú Ediciones. 
Anexos 

Anexo 1. Altar de Coricancha

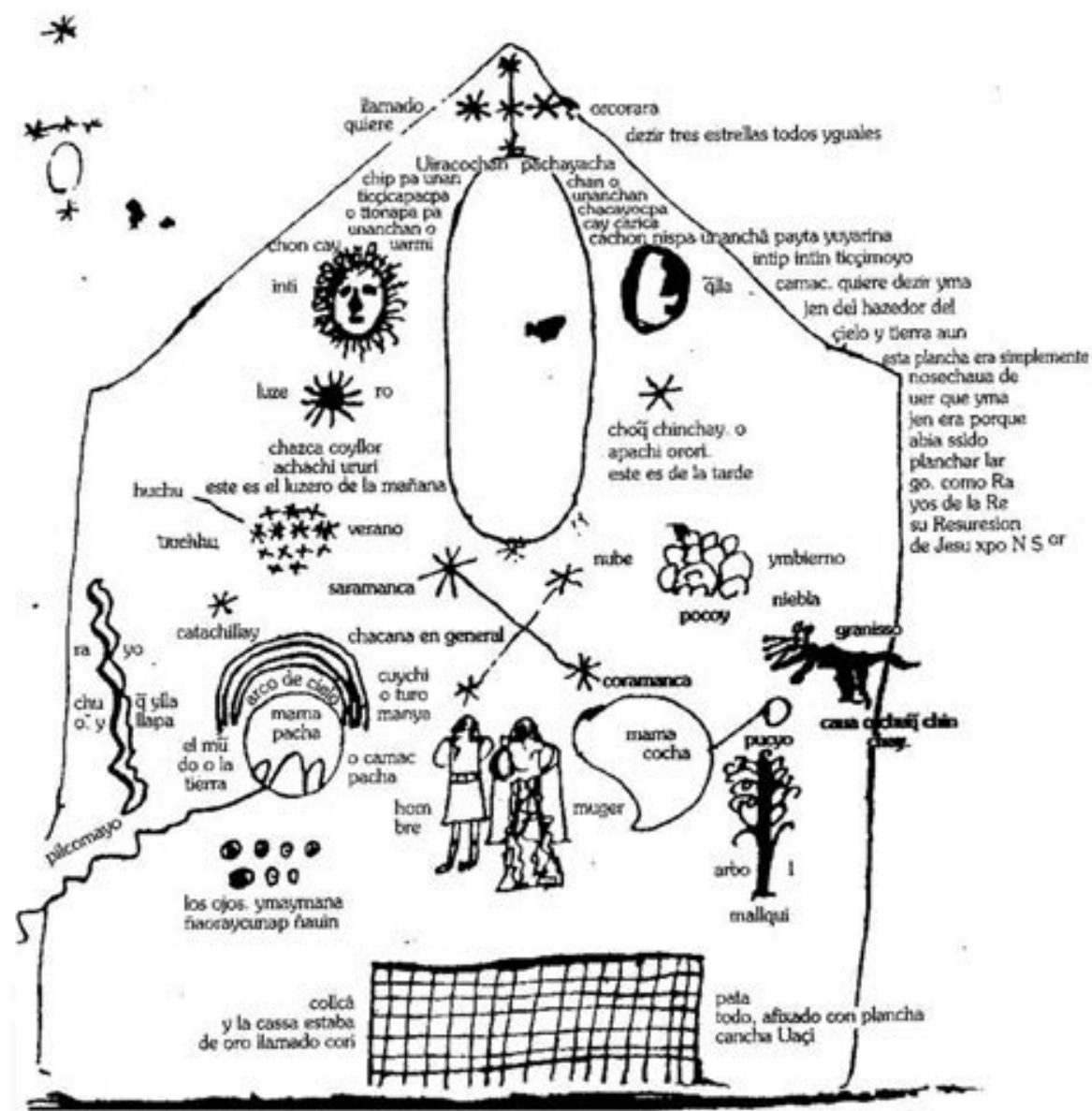

Fuente: Duvilios \& Itier, 1993; Transcripción de: Estermann, 2006, p. 333. 
Anexo 2. Cuadro con los cuatro ejes espaciales

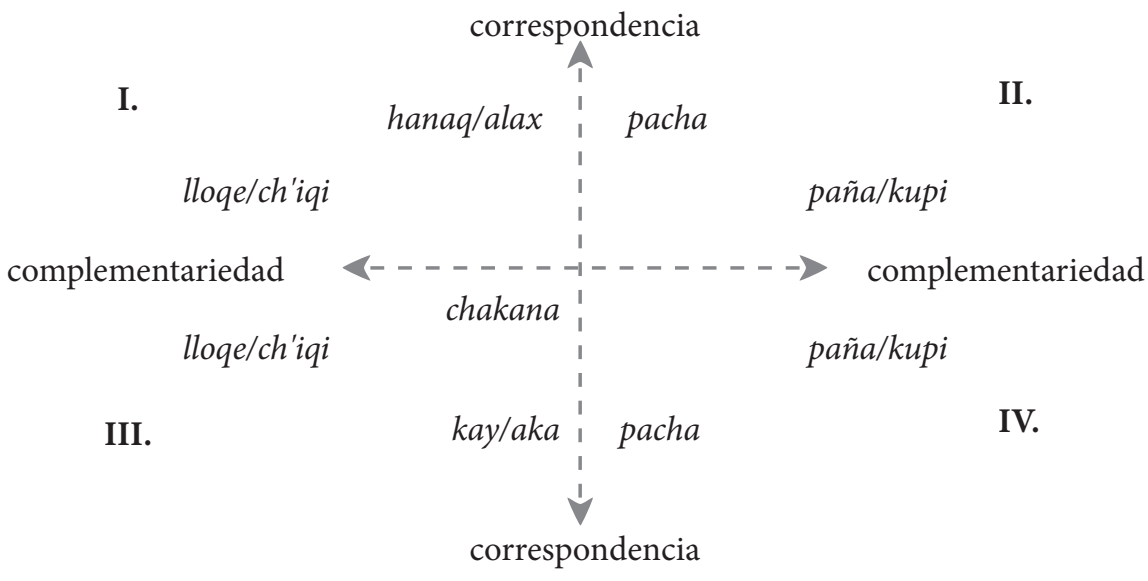

Fuente: Estermann, 2006, p. 171.

Anexo 3. Cuadro actual con ubicación de los ejes

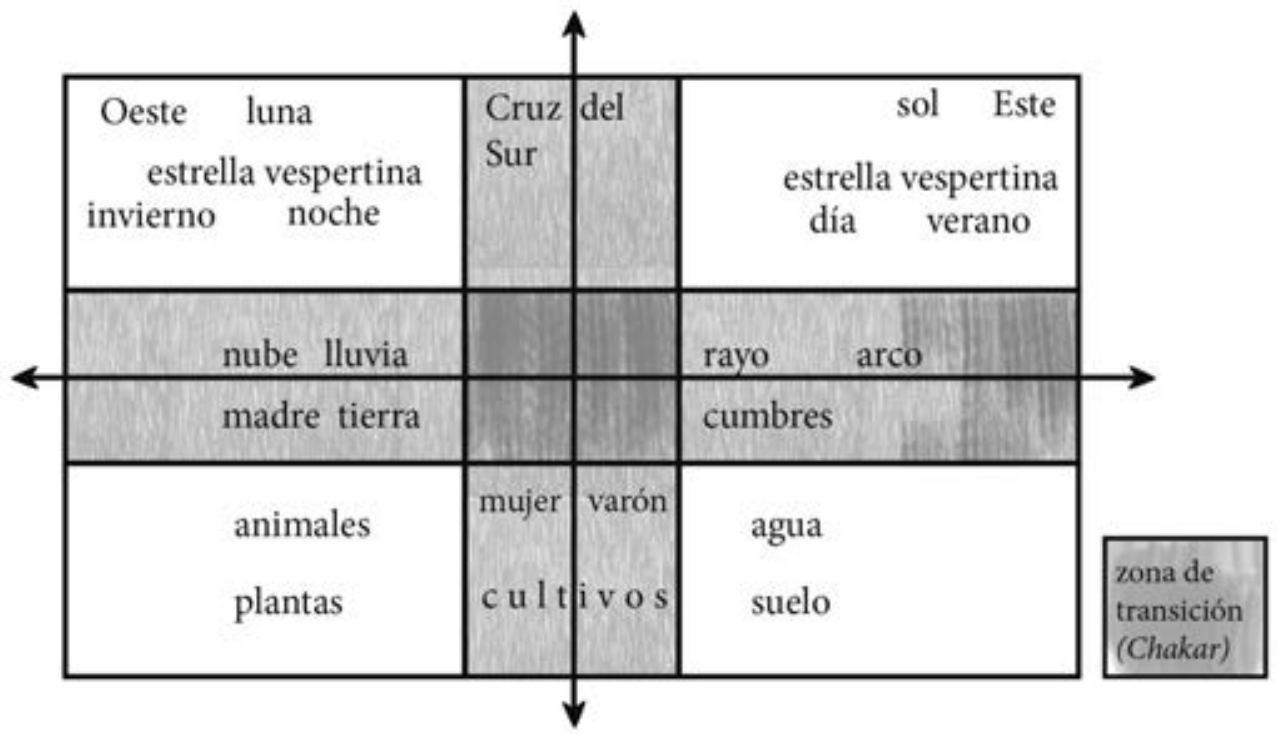

Fuente: Estermann, 2006, p. 172. 
Anexo 4. Cuadro de correspondencias principales

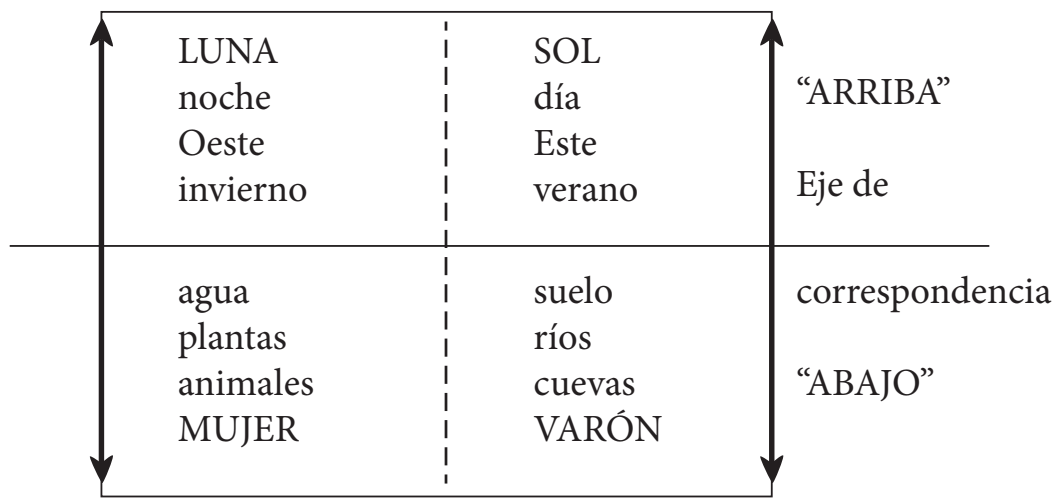

Fuente: Estermann, 2006, p. 174.

Anexo 5. Medallón incaico denominado "Placa Echenique"

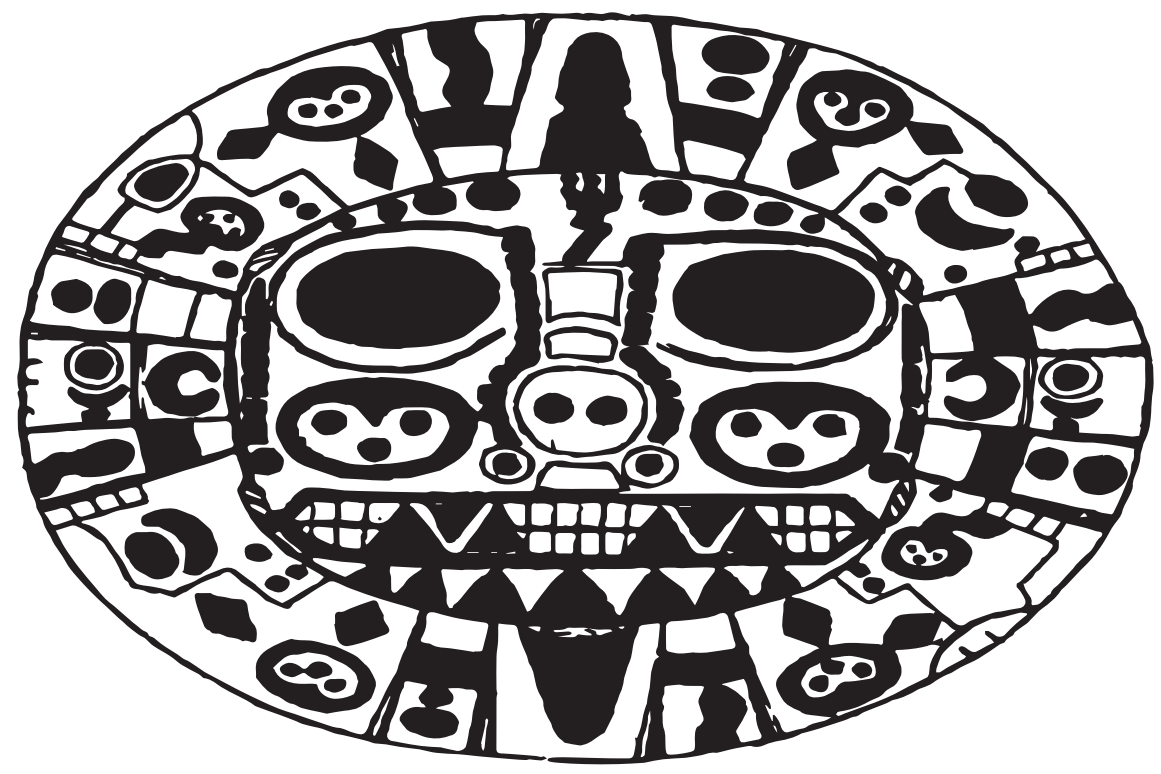

Fuente: Kusch, 2009, p. 39. 
Anexo 6. Sistema de distribución de los elementos teogónicos y calendáricos de la cosmovisión indígena

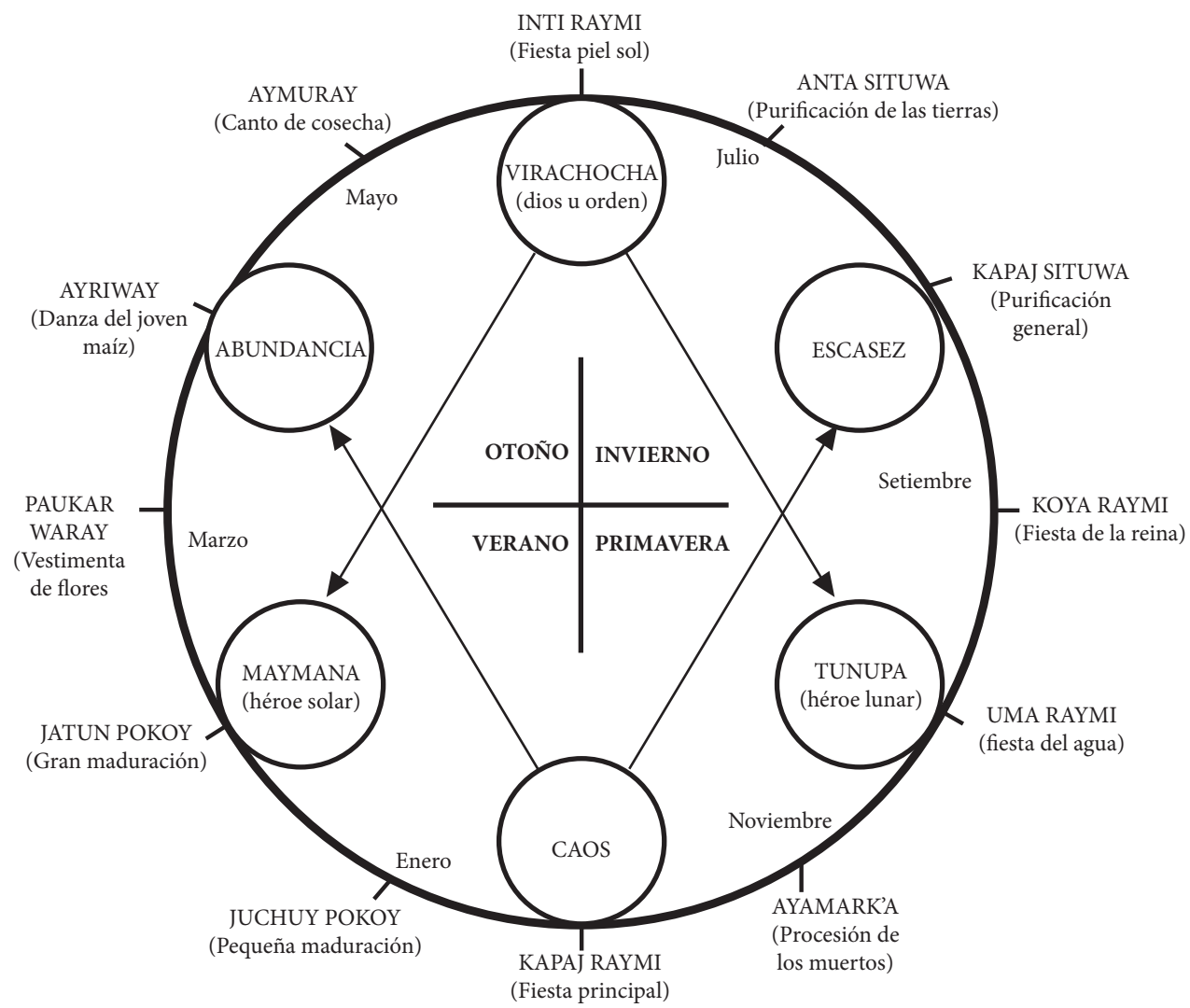

Fuente: Kusch, 2009, p. 72. 



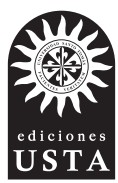

Esta obra se editó en Ediciones USTA,

Departamento Editorial de la Universidad Santo Tomás.

Se usó papel propalcote de 300 gramos para la carátula y

papel bond beige de 75 gramos para las páginas internas.

Tipografía Minion Pro y Fira Sans. Impreso por Image Printing Ltda.

2018. 


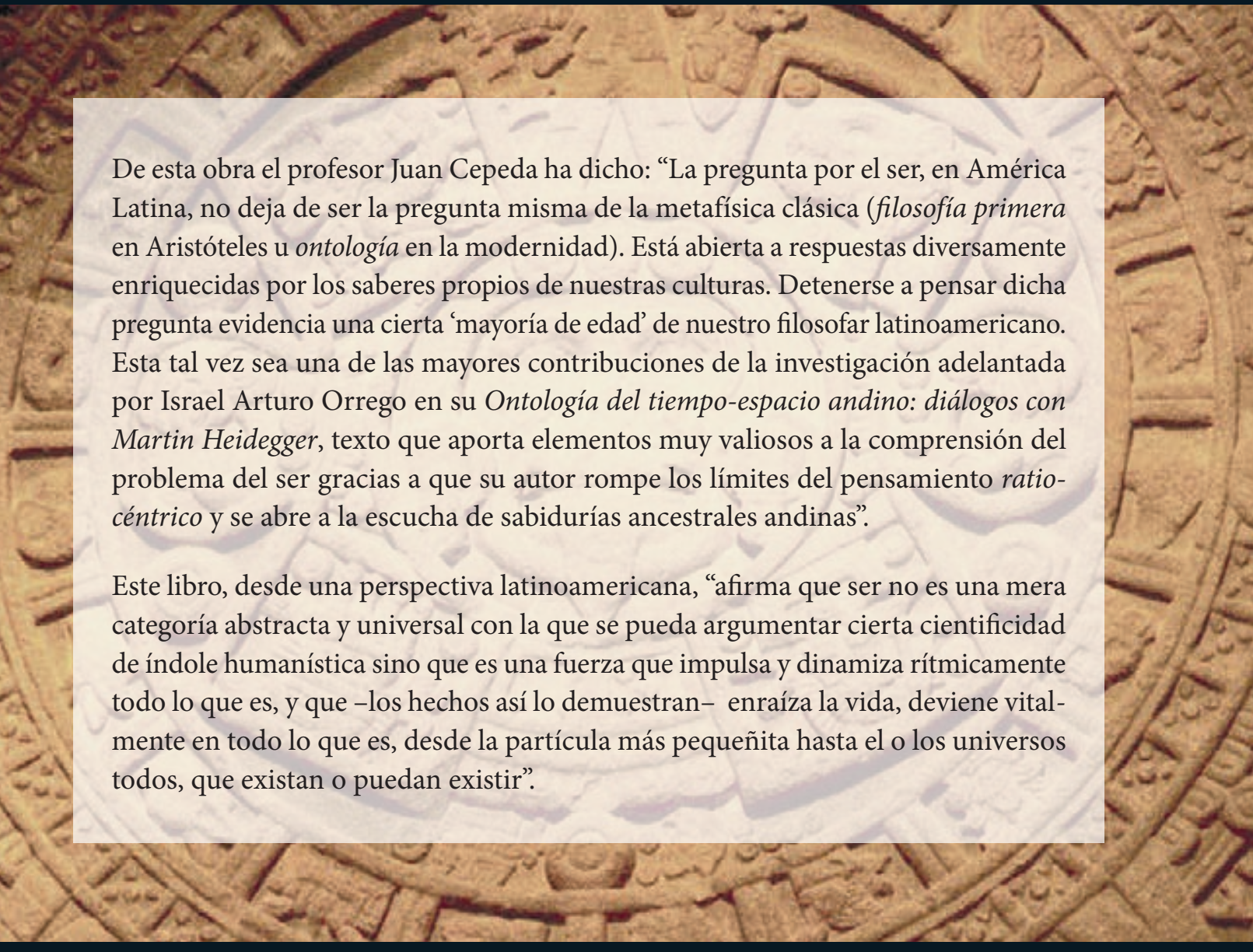

\section{Summa}

laude $0 \%$

